U.S. Department of the Interior

\title{
Ground Water in the Southern Lihue Basin, Kauai, Hawaii
}

\section{U.S. GEOLOGICAL SURVEY}

Water-Resources Investigations Report 98-4031

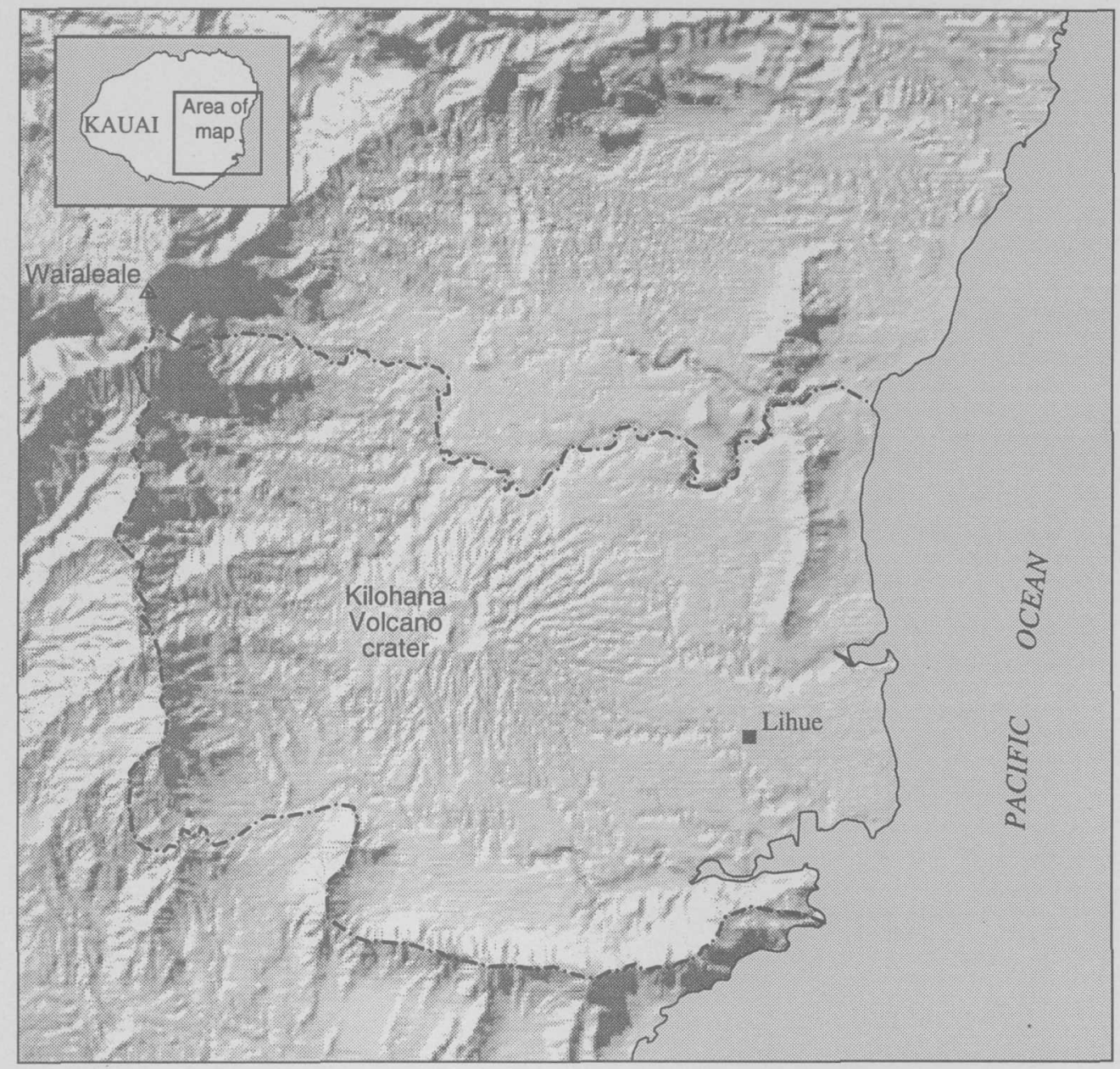

Prepared in cooperation with the

COUNTY OF KAUAI DEPARTMENT OF WATER

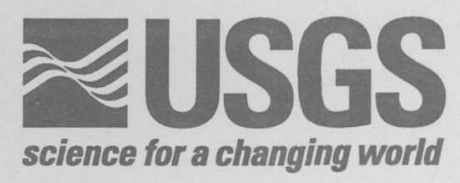





\section{Ground Water in the Southern Lihue Basin, Kauai, Hawaii}

By Scot K. Izuka and Stephen B. Gingerich

U.S. GEOLOGICAL SURVEY

Water-Resources Investigations Report 98-4031

Prepared in cooperation with the COUNTY OF KAUAI DEPARTMENT OF WATER 


\section{U.S. DEPARTMENT OF THE INTERIOR BRUCE BABBITT, Secretary}

\section{U.S. GEOLOGICAL SURVEY}

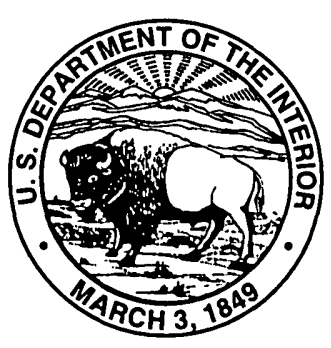

Thomas J. Casadevall, Acting Director

The use of firm, trade, and brand names in this report is for identification purposes only and does not constitute endorsement by the U.S. Geological Survey.

For additional information write to:

District Chief

U.S. Geological Survey

677 Ala Moana Blvd., Suite 415

Honolulu, $\mathrm{HI} 96813$
Copies of this report can be purchased from:

U.S. Geological Survey Branch of Information Services

Box 25286

Denver, CO 80225-0286 


\section{CONTENTS}

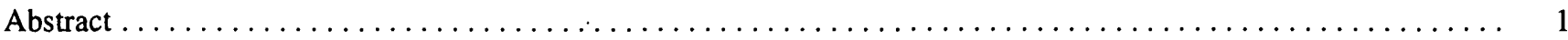

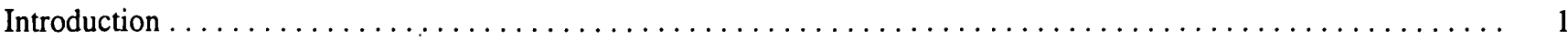

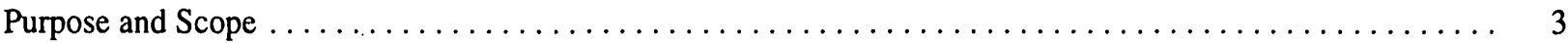

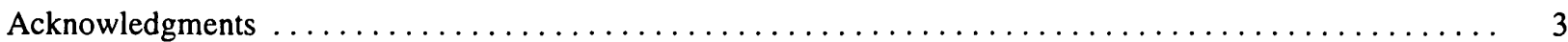

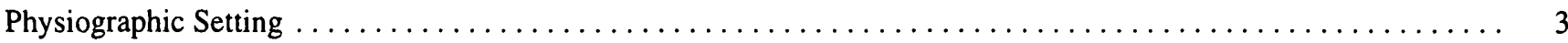

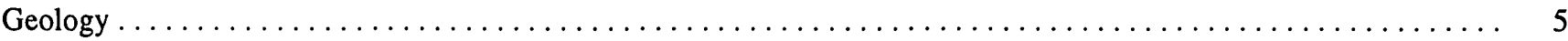

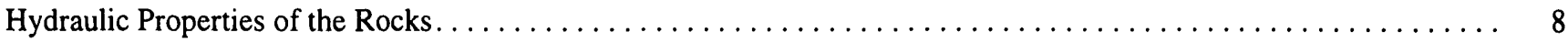

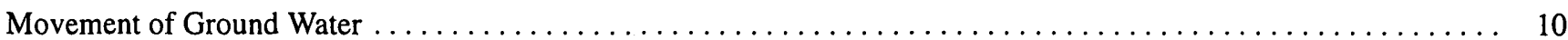

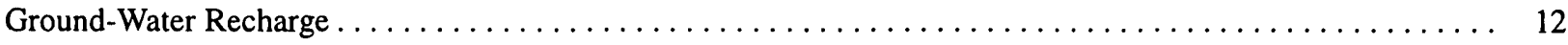

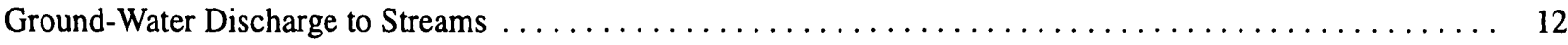

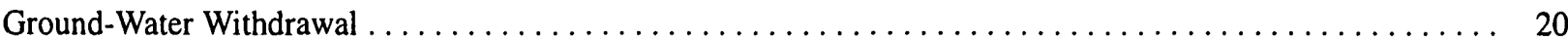

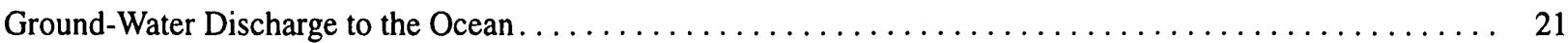

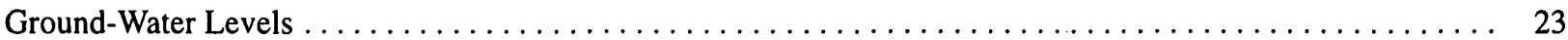

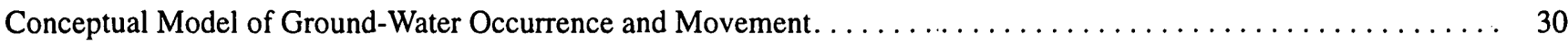

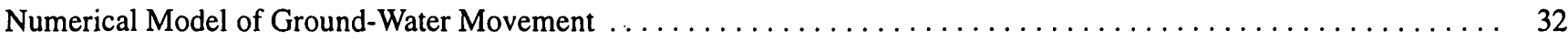

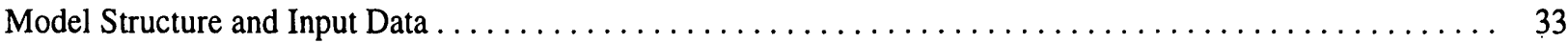

Hydraulic Conductivities, Water Levels, Ground-Water Discharge, and Interface Depth of the

Best-Fit Numerical Model. . . . . . . . . . . . . . . . . . . . . . . . . . . . . . . 40

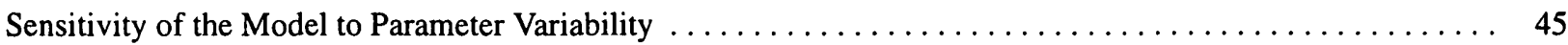

Implications of the Numerical Model for Ground-Water Occurrence $\ldots \ldots \ldots \ldots \ldots \ldots$

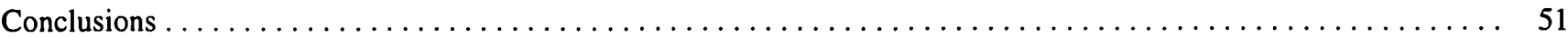

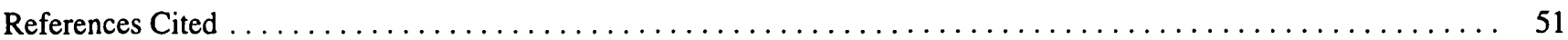

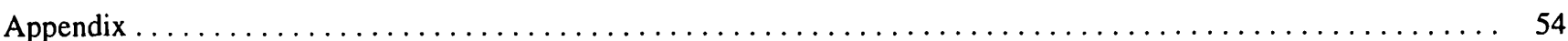

\section{Figures}

1-3. Maps showing:

1. Location of the southern Lihue Basin, Kauai, Hawaii. . . . . . . . . . . . . . . . 2

2. Rainfall distribution in the southern Lihue Basin, Kauai, Hawaii . . . . . . . . . . . . . 4

3. Geology of the Lihue Basin, Kauai, Hawaii $\ldots \ldots \ldots \ldots \ldots \ldots \ldots \ldots \ldots \ldots \ldots \ldots \ldots \ldots \ldots \ldots \ldots \ldots \ldots \ldots$

4. Block diagram showing the structure and stratigraphy of the southern Lihue Basin, Kauai $\ldots \ldots \ldots 7$

5. Map showing locations of wells and well fields in southeastern Kauai, Hawaii . . . . . . . . . . . . . . 9

6. Generalized section through the southern Lihue Basin, Kauai, Hawaii showing the relation between freshwater and saltwater and the direction of movement within the freshwater body under pristine

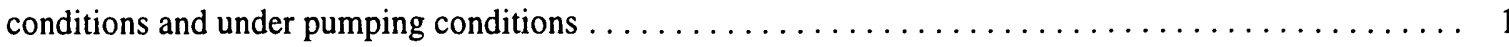

7-8. Maps showing:

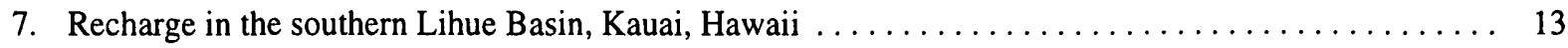

8. Locations of continuous stream-gaging stations in southeastern Kauai, Hawaii. . . . . . . . . . . . 14

9-10. Graphs of:

9. Rainfall and hydrographs for selected continuous stream-gaging stations in southeastern Kauai, Hawaii. 16 
10. Total discharge and base flow at continuous stream-gaging stations on streams in southeastern Kauai, Hawaii . . . . . . . . . . . . . . . . . . . . . . . . . . . . . .

11. Map showing ground-water discharge measured by instantaneous discharge measurements on selected

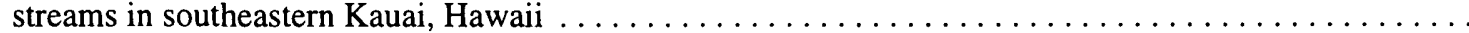

12-13 Graphs showing:

12. Water levels compared with depth of drilling for selected wells in the A, Haiku and Puhi; and B, Kilohana and Lihue Town well fields, Kauai, Hawaii $\ldots \ldots \ldots \ldots \ldots \ldots \ldots \ldots \ldots \ldots \ldots$

13. Correlation of abrupt water-level declines with drillers' logs from selected wells in the southern

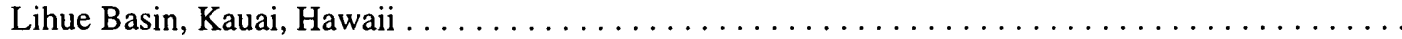

14. Diagram showing correlation of abrupt water-level declines in the southern Lihue Basin, Kauai, Hawaii ... 27

15. Generalized water-table map and profile for data from 1910 through 1996 for the southern Lihue

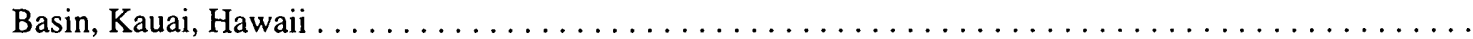

16-21. Diagrams showing:

16. Ground-water flow in the southern Lihue Basin, Kauai, Hawaii

17. Discretization grid, boundaries, streams, pumping wells, and monitoring points used in the numerical ground-water model of the southern Lihue Basin, Kauai, Hawaii . .

18. Distribution of geology used in the numerical ground-water model of the southern Lihue Basin,

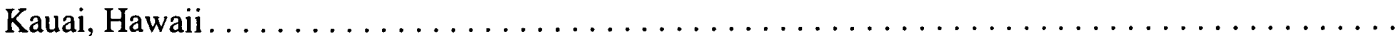

19. Distribution of recharge in the numerical ground-water model of the southern Lihue Basin,

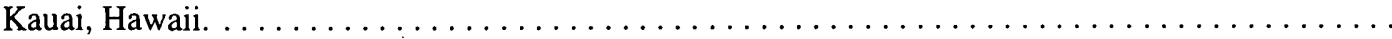

20. Distribution of simulated head in the upper layer and lower layer of the numerical groundwater model of the southern Lihue Basin, Kauai, Hawaii . . . . . . . . . . . . . . .

21. Simulated elevation of freshwater/saltwater interface in the upper layer and lower layer of the numerical ground-water model of the southern Lihue Basin, Kauai, Hawaii. . . . . . . . . . . . .

22-23. Graphs showing:

22. Variation of simulated head with streambed and ocean-floor leakance in the numerical groundwater model of the southern Lihue Basin, Kauai, Hawaii . . . . . . . . . . . . . .

23. Comparison of observed water levels compared with simulated water levels for selected values of horizontal hydraulic conductivities $\left(K_{h}\right)$ in the Koloa Volcanics, southern Lihue Basin,

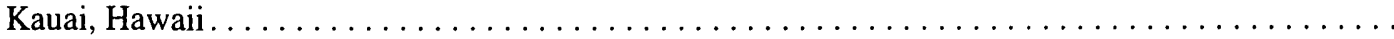

\section{Tables}

1. Summary of base-flow analyses for selected streams in southeastern Kauai, Hawaii . . . . . . . . . . . 15

2. Reported withdrawals from wells in southeastern Kauai, Hawaii $\ldots \ldots \ldots \ldots \ldots \ldots$

3. Well water-level information used to construct the generalized water-table map, southern Lihue Basin,

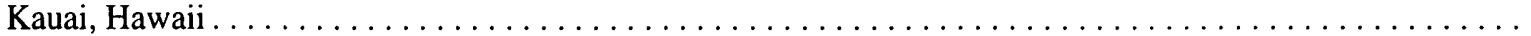

4. Summary of selected characteristics and input data of the numerical model of the southern Lihue Basin,

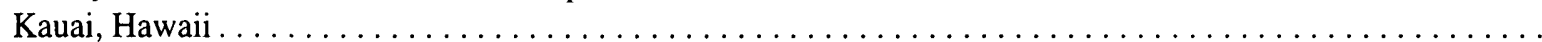

5. Withdrawal rates in simulated pumping wells used in the numerical ground-water model of the southern

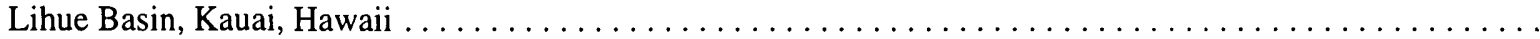

6. Hydraulic conductivities used in the best-fit numerical ground-water model of the southern Lihue Basin, Kauai, Hawaii

7. Observed and simulated water levels from the upper layer of the numerical ground-water model of the

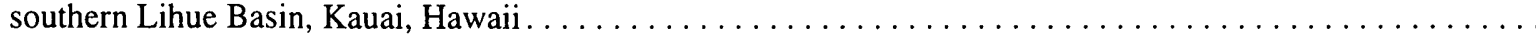

8. Simulated ground-water discharge to streams, rivers, and the ocean in the best-fit numerical ground-water model of the southern Lihue Basin, Kauai Hawaii. 


\title{
Ground Water in the Southern Lihue Basin, Kauai, Hawaii
}

\author{
By Scot K. Izuka and Stephen B. Gingerich
}

\section{Abstract}

A multi-phased study of ground-water resources, including well drilling, aquifer tests, analysis of ground-water discharge, and numerical ground-water modeling, indicates that the rocks of the southern Lihue Basin, Kauai, have permeabilities that are much lower than in most other areas of ground-water development in the Hawaiian islands. The regional hydraulic conductivity of the Koloa Volcanics, which dominates fresh groundwater flow in the basin, is about 0.275 foot per day. The Waimea Canyon Basalt which surrounds the basin and underlies the Koloa Volcanics within the basin is intruded by dikes that reduce the bulk hydraulic conductivity of the rocks to about 1.11 feet per day.

The low permeabilities result in steeper head gradients compared with other areas in the Hawaiian islands, and a higher proportion of groundwater discharging to streams than to the ocean. Water levels rise from near sea level at the coast to several hundreds of feet above sea level at the center of the basin a few miles inland. The high inland water levels are part of a completely saturated ground-water system. Because of the low regional hydraulic conductivity and high influx of water from recharge in the southern Lihue Basin, the rocks become saturated nearly to the surface and a variably saturated/unsaturated (perched) condition is not likely to exist. Streams incising the upper part of the aquifer drain ground water and keep the water levels just below the surface in most places. Streams thus play an important role in shaping the water table in the southern Lihue Basin. At least 62 percent of the ground water discharging from the aquifer in the southern Lihue Basin seeps to streams; the remainder seeps directly to the ocean or is withdrawn by wells.

\section{INTRODUCTION}

Kauai is the fourth-largest island $\left(553 \mathrm{mi}^{2}\right)$ in the tropical, North Pacific Hawaiian Archipelago (fig. 1). Kauai's population was about 51,000 in 1990 ; about 20 percent of the population resided in the Lihue District in the southern part of the Lihue Basin (State of Hawaii, 1991). Total ground-water withdrawal on Kauai in 1990 was estimated at about $40 \mathrm{Mgal} / \mathrm{d}$, with about $5 \mathrm{Mgal} / \mathrm{d}$ withdrawn from wells near Lihue (Shade, 1995b). Projections for water use to the year 2010 indicate that the Lihue District would need the greatest increase in water production of all districts on Kauai (Hawaii State Department of Land and Natural Resources, 1990). Since these projections were made, the destruction from Hurricane Iniki (1993) and a decline in both agriculture and tourism have slowed growth on Kauai, but the demands for water still have increased. Combined with declining production in some wells, the increased demand has compelled the Kauai County Department of Water (Kauai DOW) to actively explore for ground water in the Lihue area. Recent ground-water exploration efforts have been only moderately successful, however, in part because the geology of the basin is complex and the ground-water hydrology was poorly understood. Kauai is the most geologically complex of the eight main Hawaiian islands (Macdonald and others, 1960) and the Lihue Basin is one of the most geologically complex areas on Kauai, yet little subsurface geohydrologic information is available compared with more developed areas in Hawaii. 


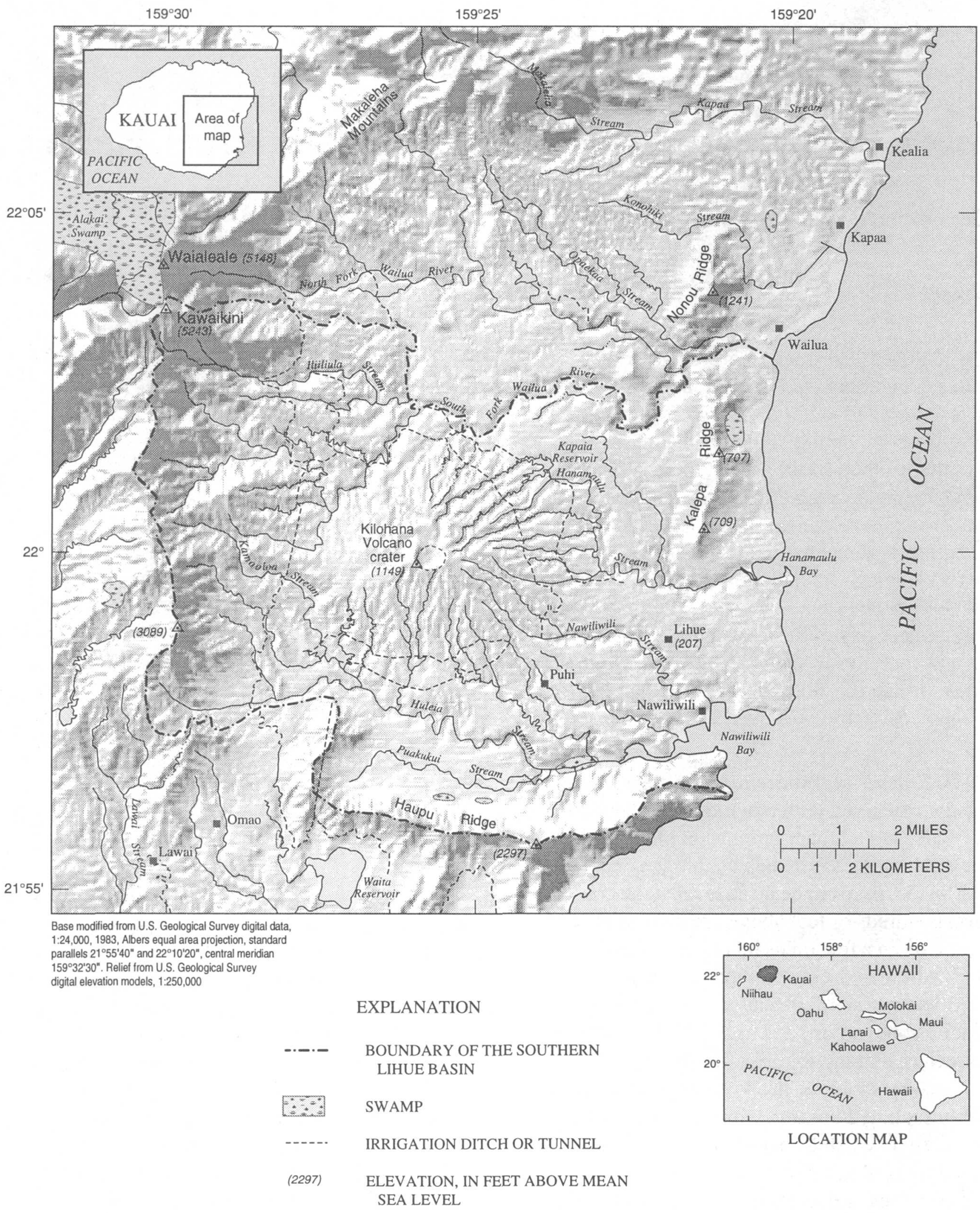

Figure 1. Location of the southern Lihue Basin, Kauai, Hawaii. 
In 1991, the Kauai DOW and the U.S. Geological Survey (USGS) began a multi-phased cooperative study of the ground-water resources of Kauai. The first phase of the study included background research, review of existing data, computation of a water-budget (Shade, 1995a) and a summary of water use in 1990 (Shade, 1995b). In 1995, the studies were focused on the southern Lihue Basin, which extends from the South Fork Wailua River to the crest of Haupu Ridge (fig. 1), where the need for resource assessment was considered most critical. The cooperative study continued with a second phase in which new ground-water data were collected and analyzed, including drilling, lithologic descriptions, and aquifer tests of six monitor wells in previously unexplored areas of the southern Lihue Basin (Gingerich and Izuka, 1997a, 1997b; Izuka and Gingerich, 1997a, 1997b, 1997c, 1997d).

\section{Purpose and Scope}

The objective of the third phase of the USGS/Kauai DOW cooperative study was to obtain a comprehensive understanding of ground-water occurrence and movement in the southern Lihue Basin. The objective was met by incorporating the diverse data from previous phases and conducting additional data collection and analyses, including (1) analysis of ground-water discharge to streams using hydrographseparation techniques and instantaneous discharge measurements, and (2) numerical ground-water modeling. This report describes the resulting understanding of the hydrogeologic system in the southern Lihue Basin.

\section{Acknowledgments}

This study was funded through a cooperative agreement between the Kauai DOW and the USGS. The authors are grateful to Kauai DOW Chief Manager and Engineer Ernest Lau, and the staff of the Kauai DOW for their cooperation and assistance. The authors are also grateful to former Kauai DOW managers Raymond Sato and Murl Nielsen, whose cooperation and assistance supported the earlier phases of the study, and to Amfac/JMB Hawaii, Lihue Plantation, Grove Farm Properties, Inc., and the Hawaii State Department of Land and Natural Resources, for permitting access to private and public lands. Ground-water withdrawal data were provided by the Hawaii State Commission on Water Resource Management.

\section{PHYSIOGRAPHIC SETTING}

The Lihue Basin is a large semicircular depression in the southeast quadrant of Kauai (fig. 1). The western margin of the basin is formed by the high central mountains of Kauai, including Mt. Waialeale and Mt. Kawaikini. To the north, the Makaleha Mountains extend from Kauai's central mountains and gradually decrease in elevation toward the coast. The southern margin of the basin is formed by Haupu Ridge which terminates abruptly in steep cliffs at the coast. Kalepa Ridge and Nonou Ridge form a line of smaller mountains near the eastern coastline. In the south-central part of the basin lies the broad dome of the Kilohana Volcano.

Rainfall distribution in the basin is primarily governed by the orographic effect (fig. 2). Precipitation is heaviest where the prevailing northeasterly trade winds encounter the windward flanks of Kauai's central mountains, forcing warm, moist air into the cool, higher elevations. Average annual rainfall ranges from about $50 \mathrm{in} / \mathrm{yr}$ at low-lying coastal areas to more than 400 in/yr near the crest of Kauai's central mountains (Giambelluca and others, 1986).

The southern Lihue Basin is drained by numerous perennial streams and rivers (fig. 1). The largest of these is the Wailua River, which flows eastward from the high-rainfall areas of Mt. Waialeale, across the basin floor, through a gap between the Kalepa and Nonou Ridges, and empties into the Pacific Ocean off the eastern coast. The flanks of Kilohana Volcano are dissected by numerous small streams that flow into larger perennial trunk streams. Small streams from the northwestern flank of Kilohana Volcano flow to the South Fork Wailua River. Streams draining the south and southwestern flank of Kilohana Volcano flow southward to Huleia Stream, which flows eastward along the southern end of the basin at the base of Haupu Ridge and empties in the estuary inland from Nawiliwili Bay. Streams draining the northeast and east flanks of the Kilohana Volcano flow into Nawiliwili and Hanamaulu Streams.

Much of the gently sloping land in the Lihue Basin is used for sugarcane cultivation. The sugar plantations built and maintained ditches and reservoirs that have diverted and stored streamflow for irrigation since the 


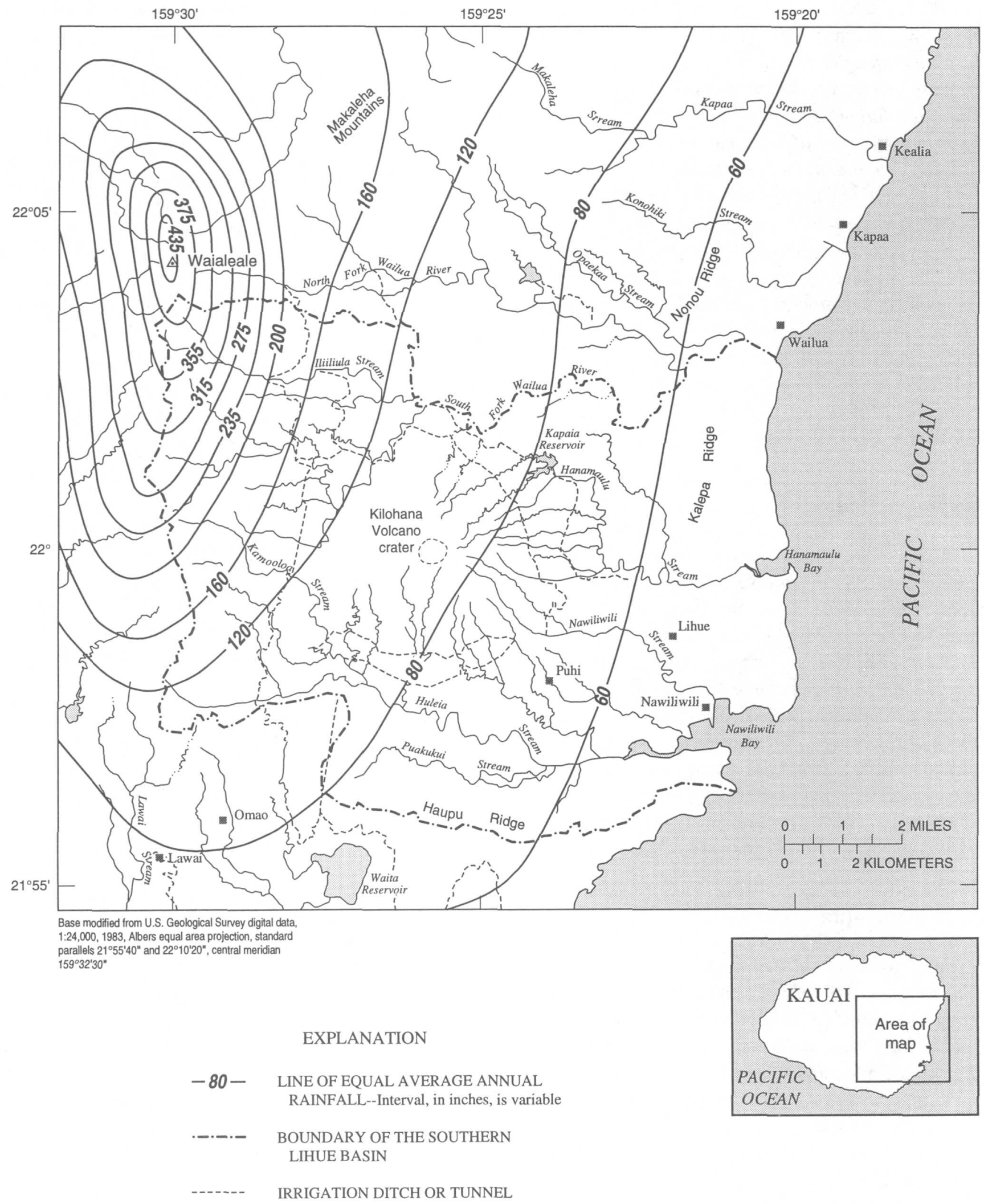

Figure 2. Rainfall distribution in the southern Lihue Basin, Kauai, Hawaii (modified from Giambelluca and others, 1986). 
late 19th century. The irrigation-ditch system not only redistributes water within the Lihue Basin, but also brings water in from and takes water out to adjacent basins. The natural drainage pattern of the Lihue Basin has thus been modified into a network of natural stream channels crossed by agricultural ditches. Most stream reaches in the basin are regulated in some way by upstream diversions. Beginning in the 1970's and continuing into the 1990's, many sugar plantations in Hawaii closed. The Lihue Basin is one of the few remaining areas still growing sugarcane in Hawaii, but the area of the basin involved in sugar production has been greatly reduced. Much of the former sugar production land near the town of Puhi has been converted to other agricultural or residential uses.

\section{GEOLOGY}

A comprehensive study of the geology, including a geologic map of the island, and water resources of Kauai was compiled by Macdonald and others (1960). Although Macdonald and others (1960) referred to their geologic mapping as "reconnaissance," their descriptions established the geologic framework of the island and remain the primary source of structural and stratigraphic information on Kauai. Later investigations, including petrologic and geochemical analyses (Macdonald, 1968; Feigenson, 1984; Clague and Dalrymple, 1988, Maaloe and others, 1992, Holcomb and others, 1997), a gravity survey (Kivroy and others, 1965), and offshore sonar mapping (Moore and others, 1989) indicate that the geology of the basin is more complex than described in the earlier studies.

According to the geologic history described by these previous works, Kauai was built up from the Pacific Ocean floor during the early Pliocene by midplate, hot-spot volcanism which created a large shield volcano similar in structure to the younger shield volcanoes of other islands in the Hawaiian Archipelago. Because of Kauai's comparatively advanced age (the bulk of Kauai was built in the Miocene and Pliocene, whereas most of the major islands in Hawaii are Pliocene and younger; Langenheim and Clague, 1987), its original form has been greatly modified by erosion and the island has evolved a more complex geologic structure and stratigraphy than any of the other Hawaiian islands. During a 0.5- to 1-million-year period of relative volcanic quiescence following shield-building volcanism, stream erosion and faulting modified the surface morphology of Kauai. Large valleys, canyons, and other depressions, including the Lihue Basin, were formed and thick sediments accumulated on the eroded, faulted surfaces. This period of volcanic quiescence, erosion, and faulting was followed by rejuvenated volcanism that partly covered the landscape in the late Pliocene and Pleistocene.

The origin of the circular Lihue Basin has been debated since the earliest studies of Kauai. Stearns $(1946,1985)$ contended that the basin is the result of advanced stream erosion and the coalescing of many amphitheater-headed valleys. Macdonald and others (1960), favor the hypothesis that the depression was formed by collapse in a manner similar to caldera formation in shield volcanoes. Kivroy and others (1965) mapped a gravity anomaly that is similar to anomalies mapped beneath calderas of other Hawaiian volcanoes. Holcomb and others (1997) suggest that the Lihue Basin is part of a younger shield volcano that grew along the collapsed eastern flank of an older western shield volcano that had built the bulk of Kauai.

Although the structure and geologic history of the Lihue Basin is currently debated, most hypotheses agree on stratigraphic nomenclature. The rocks of the Lihue Basin are divided into two geologic formations which are separated by erosional unconformities (Macdonald and others, 1960; Langenheim and Clague, 1987). The bulk of Kauai is composed of the tholeiitic Waimea Canyon Basalt which formed during the shield-volcano-building period of Kauai's geologic history (fig. 3). In the Lihue Basin, the Waimea Canyon Basalt forms the basement on which younger sediments and volcanic rocks lie, but crops out only in the ridges and mountains surrounding and within the basin (fig. 4). Most of the Waimea Canyon Basalt in the Lihue Basin belongs to the Napali Member, which consists of thick accumulations of thin lava flows.

The geologic map of Macdonald and others (1960) shows numerous sheet-like volcanic dikes cutting vertically into the lava flows in the ridges where the Waimea Canyon Basalt is exposed. In the Koolau Volcano on Oahu, where dikes exposed by deep erosion have been studied intensively, the dikes are concentrated in the area of the ancient caldera and in narrow bands of the ancient rift zones and are rare in the flanks of the 


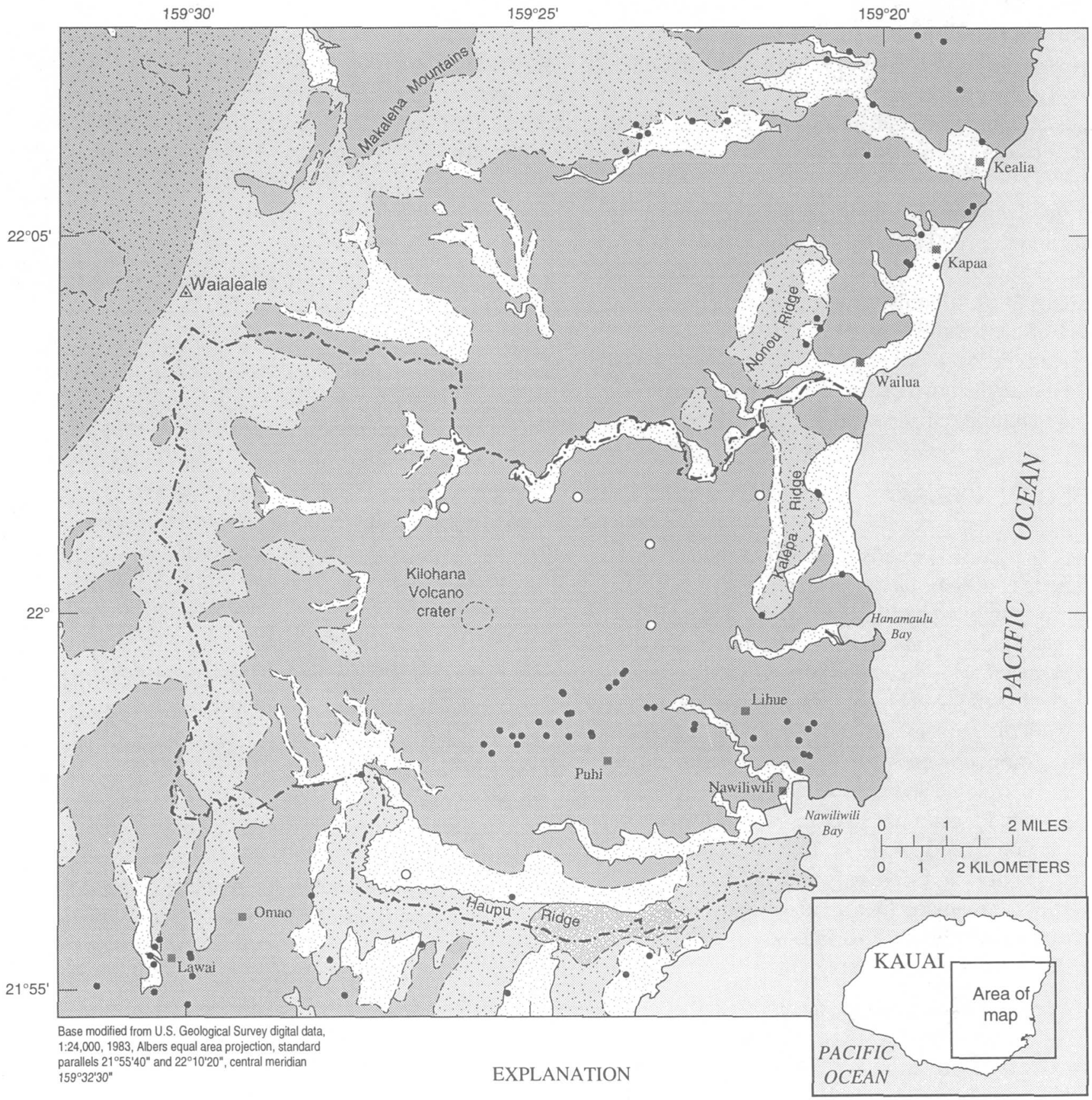

$159^{\circ} 32^{\prime} 30^{\prime \prime}$

SEDIMENTARY DEPOSITS (Holocene and Pleistocene)

KOLOA VOLCANICS (Pleistocene and Pliocene)

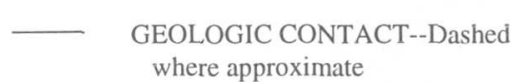

WAIMEA CANYON BASALT (Pliocene and Miocene?)

Olokele Member (Pliocene)

Haupu Member (Pliocene)

Napali Member (Pliocene and Miocene?)
GEOLOGIC CONTACT--Dashed
where approximate

---- BOUNDARY OF SOUTHERN LIHUE BASIN

O MONITOR WELL

- EXISTING WELL

Figure 3. Geology of the Lihue basin, Kauai, Hawaii (modified from Macdonald and others, 1960). 


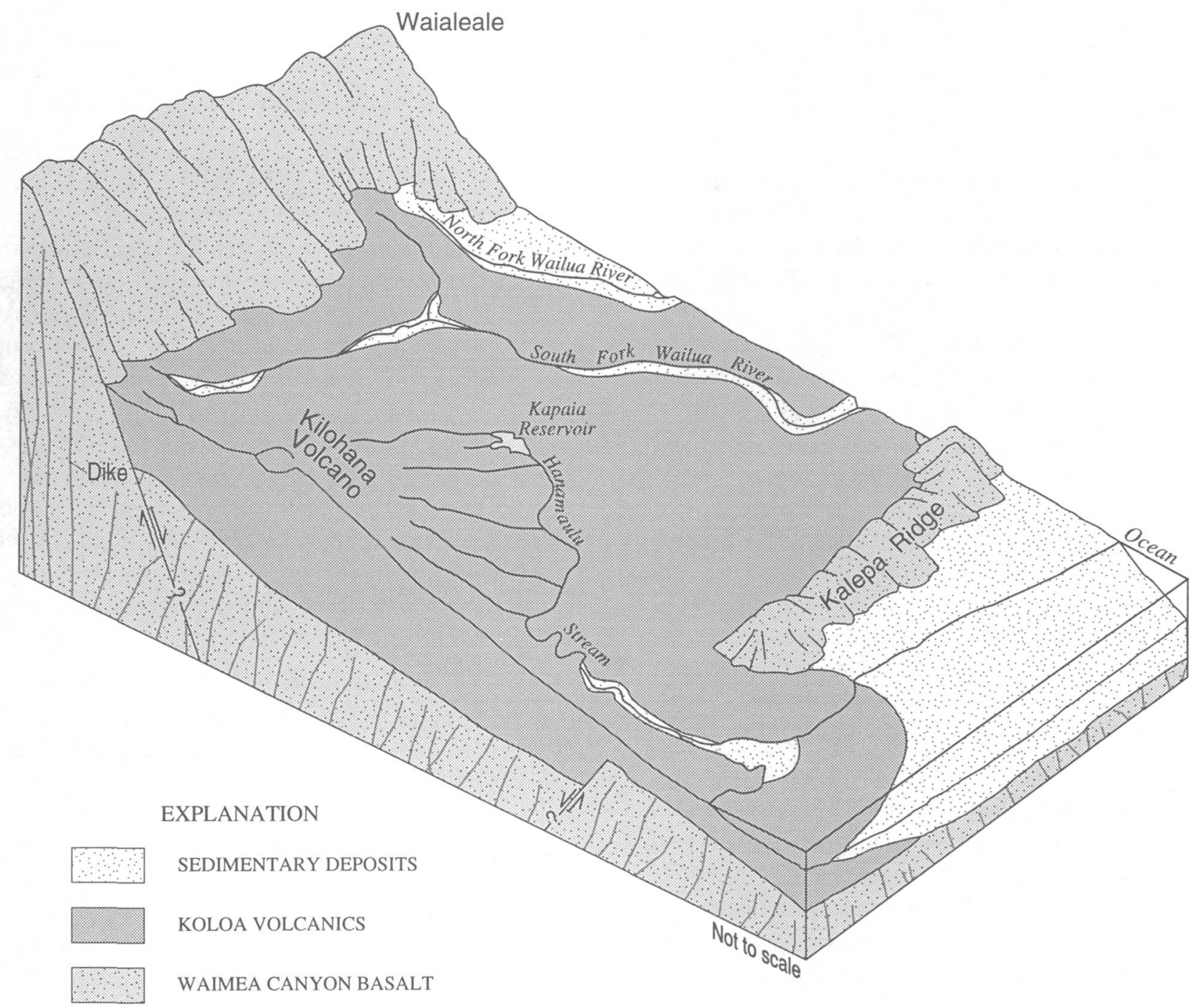

Figure 4. Block diagram showing the structure and stratigraphy of the southern Lihue Basin, Kauai, Hawaii.

volcano (Takasaki and Mink, 1985; Walker, 1987). Although the location of calderas and rift zones is not well defined on Kauai, dike concentrations in the ridges surrounding the Lihue Basin and evidence that the Lihue Basin is the site of an ancient caldera (Holcomb and others, 1997) indicate that dikes probably also are present in the Waimea Canyon Basalt below the floor of the Lihue Basin. Rejuvenated-stage volcanic edifices on the basin floor probably also were fed by dikes that cut across the Waimea Canyon Basalt beneath the floor of the basin. Outcrops of the Waimea Canyon Basalt south of Waialeale and west and south of Haupu Ridge are composed of flank lava flows with fewer dikes (Macdonald and others, 1960).

At the northwest boundary of the basin near Mt. Waialeale is an outcrop of the thick-bedded lava flows of the Waimea Canyon Basalt's Olokele member, which Macdonald and others (1960) interpreted as 
caldera fill. Alternatively, Holcomb and others (1997) propose that the thick-bedded lavas of the Olokele Member accumulated between an older western shield volcano and a younger eastern shield volcano.

Resting unconformably on the eroded surface of the Waimea Canyon Basalt are volcanic rocks and intercalated sediments of the Koloa Volcanics of Pliocene and Pleistocene age (Macdonald and others, 1960; Langenheim and Clague, 1987). The volcanic rocks include thick, massive lava flows of highly alkalic mafic rocks including alkalic olivine basalt, nephelinite, melilitite, and basanites that were erupted during a period of rejuvenated volcanism from edifices scattered over the old, eroded shield volcano and fill valleys, gorges, and depressions in the Waimea Canyon Basalt. The sedimentary rocks include breccias, conglomerates, unconsolidated gravels, limestones, and marine muds. Volcanic activity during the formation of the Koloa Volcanics was apparently sporadic and variable in eruptive style, and periods of inactivity were sufficiently long to allow deposition of thin sediment layers between lava flows. As a result, the Koloa Volcanics are a heterogeneous unit that includes variously weathered lava flows, ash, tuff, cinder, and sediments (Macdonald and others, 1960).

The Koloa Volcanics in the Lihue Basin have accumulated to great thicknesses. A geologic cross section in the geologic map of Macdonald and others (1960) shows the contact between Koloa Volcanics and the underlying Waimea Canyon Basalt at about $-500 \mathrm{ft}$ elevation, but exploratory wells drilled in the USGSKauai DOW cooperative study indicate the Koloa Volcanics may be thicker in some places (Izuka and Gingerich, 1997a, 1997b, 1997c, 1997d).

The youngest stratigraphic units are the sedimentary rocks of Pleistocene and Holocene age that form coastal plains and fill valley bottoms. These sediments include fluvial and colluvial gravels and conglomerates as well as sand-dune, beach, and lagoon deposits.

\section{HYDRAULIC PROPERTIES OF THE ROCKS}

Most of the ground water developed in the Lihue Basin comes from wells in the Koloa Volcanics because the formation covers most of the surface of the basin. A few wells in the basin produce water from the Waimea Canyon Basalt. The Pleistocene and Holocene sedi- ments in the basin are thin, have limited areal extents, have not been developed much for water or studied hydrologically, and therefore are not discussed as a separate hydrogeologic unit in this report. For discussion purposes, some dense clusters of wells have been grouped into well fields (fig. 5).

Koloa Volcanics.--The volcanic rocks and sediments of the Koloa Volcanics are considered one hydrogeologic unit in this report. Individual lava flows and sedimentary layers are too numerous and finely intercalated to be separated for the purposes of this regional ground-water study, and wells used to test aquifer properties in the Koloa Volcanics penetrate sedimentary and volcanic rocks. The horizontal hydraulic conductivity $\left(K_{h}\right)$ of the thick, dense, lava flows and intercalated sediments of the Koloa Volcanics varies widely in the southern Lihue Basin. Analysis of aquifer-test data indicates that $K_{h}$ ranges from less than $0.05 \mathrm{ft} / \mathrm{d}$ to greater than $100 \mathrm{ft} / \mathrm{d}$ but the regional $K_{h}$ is probably less than 1 $\mathrm{ft} / \mathrm{d}$ (unpub. data in USGS aquifer-test archive, Honolulu District office).

The Kilohana and Puhi well fields (fig. 5) are located in an area with a much higher permeability than the rest of the Koloa Volcanics, but the extent of this high-permeability area is limited. A stepwise decline in water levels during drilling of wells in this area also indicates the presence of multiple layers of contrasting permeabilities. An aquifer test of well 5923-02 indicates that the local $K_{h}$ is as high as $138 \mathrm{ft} / \mathrm{d}$ in an interval of the aquifer from 231 to $191 \mathrm{ft}$ above sea level. Aquifer tests from other wells in the area (5923-08 and 5824$06)$, however, indicate that the local high-permeability rocks are not extensive and that the regional permeability is low. The high-permeability area around well 5923-02 does not extend as far to the southwest as well 5824-06, where aquifer tests indicate a $K_{h}$ of about 8 $\mathrm{ft} / \mathrm{d}$, nor as far to the northeast as well 5923-08, where the $K_{h}$ is estimated to be about $0.05 \mathrm{ft} / \mathrm{d}$. There are no aquifer-test data to the northwest toward the summit of Kilohana Volcano or toward the ocean to the southeast of well 5923-02.

With continued withdrawal, the cones of depression from the Kilohana and Puhi wells may extend farther into the low-conductivity rocks, which will result in an increased rate of drawdown. Thus, although well yields appeared to be high initially, the long-term yield of the wells may be limited by the small areal extent of this more permeable part of the aquifer. Ground-water 


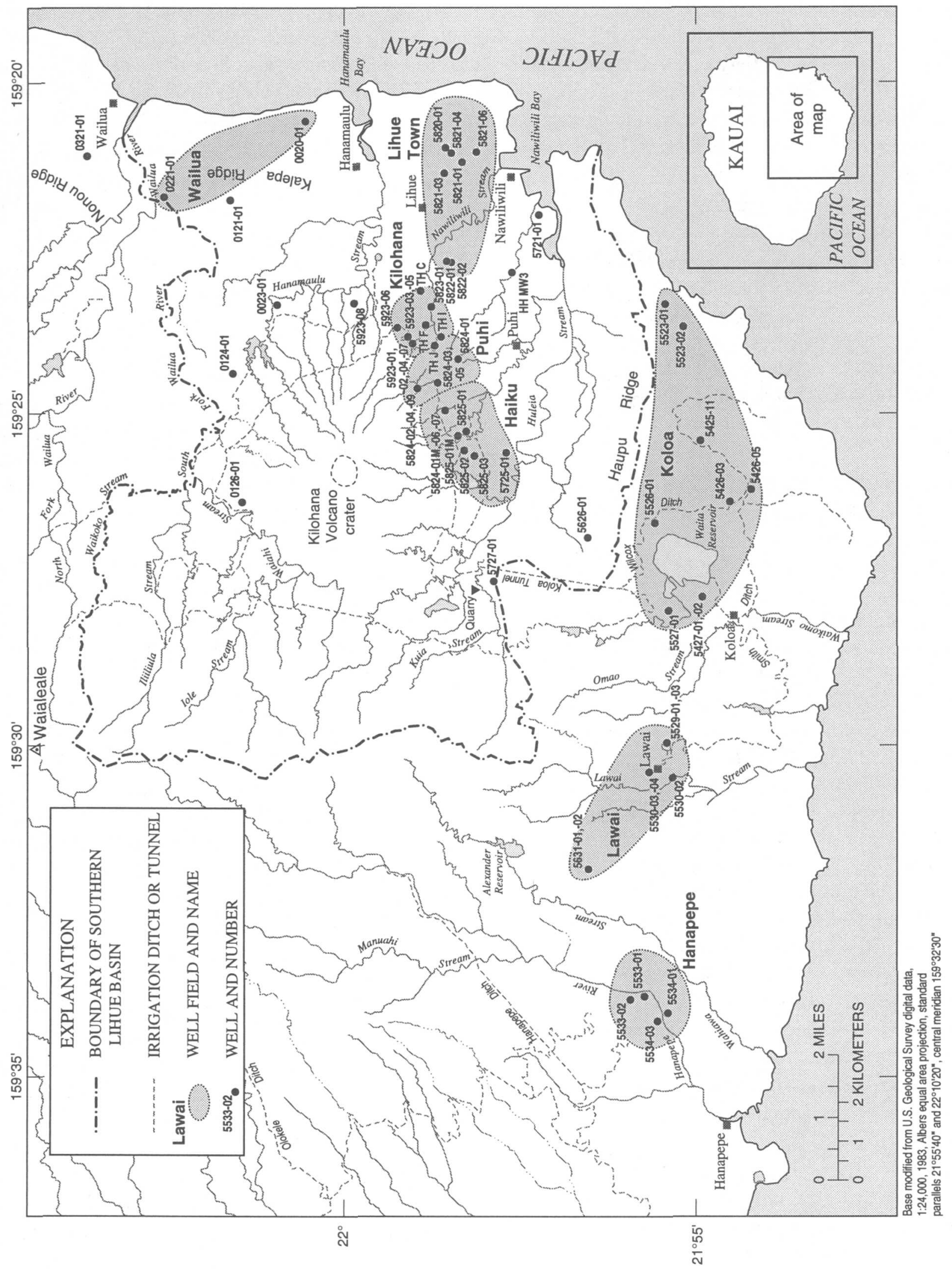

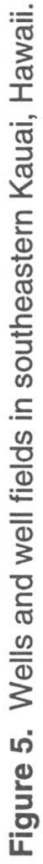


flow into this area is ultimately controlled by the regional aquifer $K_{h}$ which is about 100 times less than in this local area. Declining water levels in several wells indicate that the withdrawals have not yet reached equilibrium. Some of the shallower wells in this area have been shut down as water levels have declined over a period of more than 20 years of withdrawal (oral commun., Kauai DOW, 1996).

Waimea Canyon Basalt.--Within the Lihue Basin, the shield-building lava flows of the Waimea Canyon Basalt crop out only in ridges that were left uncovered by the younger Koloa Volcanics. These ridges are intruded by dense, low-permeability sheet-like volcanic dikes that cut vertically across the thin flank lavas. Hydrologic studies on Oahu indicate that the bulk permeability of the shield-building lavas is reduced by the presence of dikes (Takasaki and Mink, 1985; Hunt, 1996).

There is little information on the hydraulic properties of the Waimea Canyon Basalt underlying the Koloa Volcanics in the Lihue Basin, but it is likely that the Waimea Canyon Basalt is intruded by dikes as are the ridges surrounding the basin. The Waimea Canyon Basalt must at least be intruded by dikes or other intrusive igneous rocks related to the formation of the Koloa Volcanics. All of the Waimea Canyon Basalt in the Lihue Basin, including the surrounding ridges and rocks underlying the Koloa Volcanics, therefore probably consists of dike-intruded lava flows. An aquifer test at well 5626-01, which penetrates Waimea Canyon Basalt on the southern edge of the Lihue Basin on Haupu Ridge, provided an estimate of $K_{h}$ of about $19 \mathrm{ft} / \mathrm{d}$ (unpub. data in USGS aquifer-test archive, Honolulu District office) for the rocks in the immediate vicinity of the well, but the test also indicated that low-permeability structures, most likely dikes, are present some distance from the well. The bulk $K_{h}$ of the region is likely to be lower than $19 \mathrm{ft} / \mathrm{d}$ because more dikes probably lie beyond the extent of the cone of depression from the test. The nearly vertical dikes probably reduce $K_{h}$ more than the vertical hydraulic conductivity $\left(K_{v}\right)$, but the effect is not known quantitatively.

The frequency of dikes in the Waimea Canyon Basalt probably diminishes, and the bulk $K_{h}$ correspondingly increases, in the flank lava flows to the south of Haupu Ridge. On Oahu, flank lava flows, which have few dikes, have hydraulic conductivities ranging from a hundred to several thousands of feet per day (Soroos, 1973). The lavas of the Waimea Canyon Basalt on Kauai probably fall on the lower part of this range because the rocks are older and more weathered than on Oahu, but the flank lava flows of the Waimea Canyon Basalt are probably among the most hydraulically conductive rocks on Kauai.

\section{MOVEMENT OF GROUND WATER}

Fresh ground water in Kauai, as in other oceanic islands, occurs as a lenticular body which is underlain by saltwater that has permeated from the ocean (fig. 6). The freshwater is buoyed by the density difference between saltwater and freshwater. The transition from freshwater to saltwater is a diffuse zone of mixing. For simplicity, especially in aquifers where the freshwater is thick, the mixing zone can be envisioned as a sharp interface. The Ghyben-Herzberg relation, which uses the density difference between freshwater and saltwater to estimate the thickness of the freshwater body, indicates that the depth of the interface below sea level is about 40 times the elevation of the water table above sea level. The computed interface depth is commonly considered to be an approximation of the position of a 50percent freshwater and 50-percent saltwater mixture in the transition zone.

The Ghyben-Herzberg relation assumes hydrostatic or horizontal flow conditions, but the freshwater/ saltwater body in island aquifers is dynamic and has vertical as well as horizontal flow components. In the freshwater body, water flows downward in inland parts of the aquifer where recharge is highest, horizontally to the coast, then upward near the coast where ground water discharges at gaining streams and coastal springs (fig. 6). In a pristine condition, the flow in the freshwater body is in a state of long-term average dynamic equilibrium. Although seasonal or other climatic variations may result in short-term imbalances, over a number of years the average recharge rate is balanced by the average discharge rate, thus satisfying the law of conservation of mass. The size of the freshwater body is a function of aquifer size, shape, permeability, storage, and recharge. In this state of equilibrium, freshwater flows continuously but the size of the freshwater body does not change. If recharge fluctuates because of climatic or other changes, the size of the freshwater body will change and discharge will adjust accordingly so that a new equilibrium is achieved. 


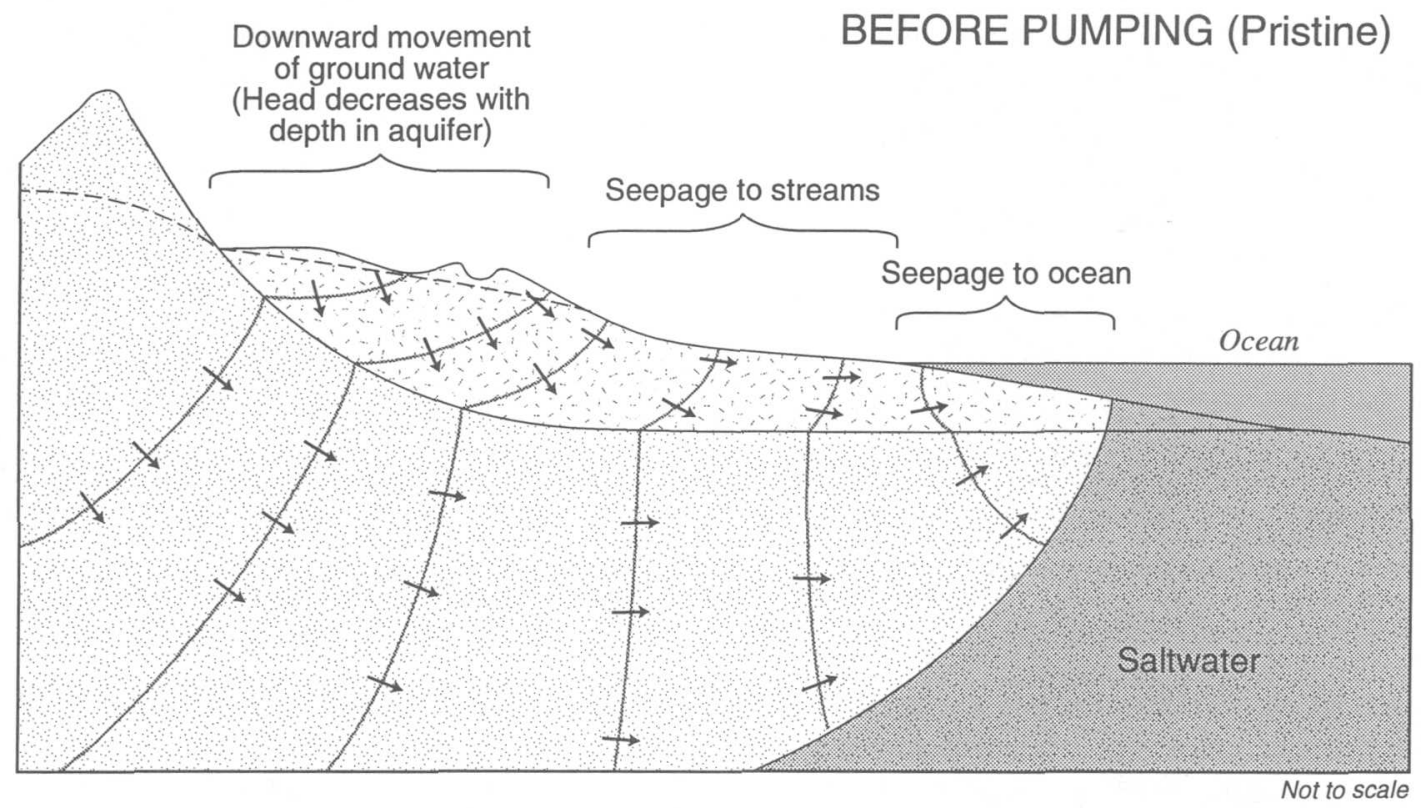

\section{EXPLANATION}

KOLOA VOLCANICS

WAIMEA CANYON BASALT

LINE OF EQUAL FRESHWATER HEAD

WATER TABLE

$\rightarrow \quad$ DIRECTION OF GROUND-WATER MOVEMENT

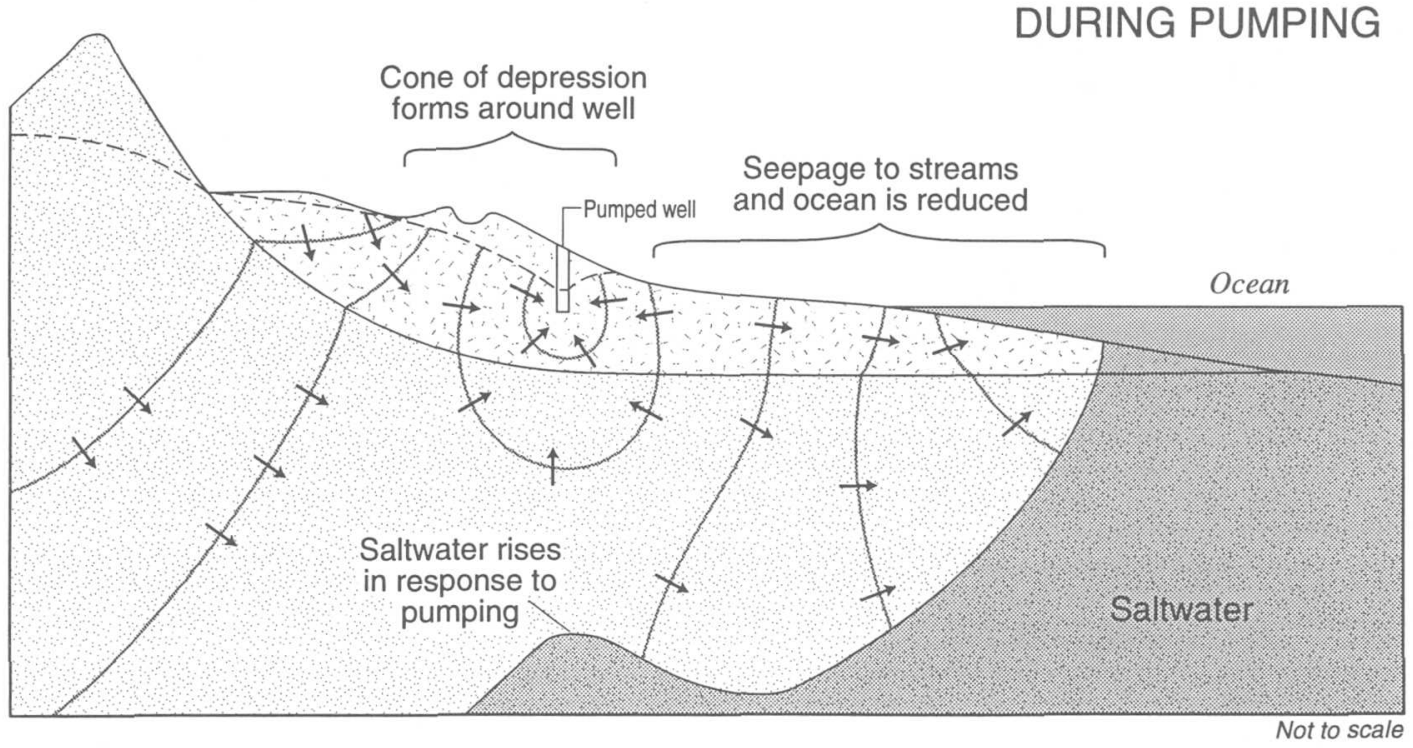

Figure 6. Generalized section through the southern Lihue Basin, Kauai, Hawaii, showing the relation between freshwater and saltwater and the direction of movement within the freshwater body under pristine conditions and under pumping conditions. 
When the natural balance is upset by artificial withdrawals, such as pumping from wells, the shape and size of the freshwater body is reduced (fig. 6). The artificial withdrawal causes the freshwater body to shrink not only by lowering the water table but by inducing saltwater to rise in response to a reduction in the mass of overlying freshwater. In response to the withdrawal, some recharge may be induced, but most of the withdrawal is balanced by a reduction in groundwater storage and natural discharge to streams and coastal springs.

Limitations to ground-water yield.--If withdrawal from wells is excessive, saltwater may rise and intrude the wells. Saltwater intrusion is a major limitation to well yields in oceanic island aquifers. Also, when water is withdrawn from a well, a cone of depression is created that lowers the water table around the well (fig. 6). As the cone of depression spreads, it lowers water levels (including water levels of other wells) in an increasingly large area. The cone of depression also spreads to areas of natural ground-water discharge such as streams or the ocean, where it will cause a reduction in the rate of ground-water discharge. The cone of depression will not stop growing until it reduces natural ground-water discharge to compensate for the withdrawal rate. Well withdrawal thus has the eventual effect of lowering the water table and reducing streamflow and ocean discharge. Long-term well yields may be limited if large streamflow reductions or water-table declines are not desired.

\section{Ground-Water Recharge}

The natural source of freshwater recharging the aquifer is rainfall infiltration. In addition to this natural recharge, irrigation water, captured from surface runoff, also can contribute to ground-water recharge. A monthly water budget for Kauai computed by Shade (1995a) indicates that ground-water recharge varies seasonally with a high in January $(981 \mathrm{Mgal} / \mathrm{d}$ islandwide recharge) to a low in June ( $454 \mathrm{Mgal} / \mathrm{d}$ islandwide recharge). The southern Lihue Basin has an average recharge of about $130 \mathrm{Mgal} / \mathrm{d}$. The pattern of recharge in the southern Lihue Basin (fig. 7) is similar to the pattern of rainfall (fig. 2). Recharge is highest near Mt. Waialeale (exceeding $150 \mathrm{in}$. of average annual recharge) and lowest in the coastal areas (less than $10 \mathrm{in.} \mathrm{of} \mathrm{average} \mathrm{annual} \mathrm{recharge).} \mathrm{In} \mathrm{drier} \mathrm{areas,}$ the recharge distribution departs from the rainfall distribution because of infiltration of excess irrigation water and variations in soil moisture storage capacity (Shade, 1995a).

\section{Ground-Water Discharge to Streams}

Where the water table intersects the ground surface, ground water may discharge at springs and along streambeds. This discharge maintains a base flow in the streams even when there is no direct runoff from rain. The quantity of streamflow that is attributable to ground-water discharge in the southern Lihue Basin was estimated by discharge measurements along streams and by analyzing records of continuous stream gages. The study also included streams outside the southern Lihue Basin possibly affected by groundwater withdrawal inside the basin. Studying all of the streams and tributaries in the southern Lihue Basin and adjacent areas was not possible because the area is drained by hundreds of miles of channels, many of which have no stream-gage records. To reduce the task of characterizing base flow in the southern Lihue Basin to a manageable size, only data from the major, representative streams and rivers were studied.

Base-flow analysis of stream-gage records.--Several continuous stream-gaging stations have been operated over various periods since 1900 in the southern Lihue Basin (fig. 8 and table 1). The station with the longest continuous record, 16060000 on the South Fork Wailua River near Lihue, has been operating since 1911, but most other stations have operated for much shorter periods (Fontaine, 1995). Base-flow estimation was also complicated by artificial regulation of many streams. Most major streams and rivers in the southern Lihue Basin are regulated either by agricultural irrigation ditches that divert water from the stream or by reservoirs that store water along the stream course. Hydrographs from continuous stream-gaging stations and graphs of daily rainfall show flashy discharge peaks (which is typical of streams with steep gradients and small drainage areas) caused by rainfall, but between the peaks, base flow persists in the streams (fig. 9). This persistent base flow indicates that ground-water discharge to streams in the southern Lihue Basin is substantial.

Base flow was estimated from available continuous streamflow records by using a computer program 


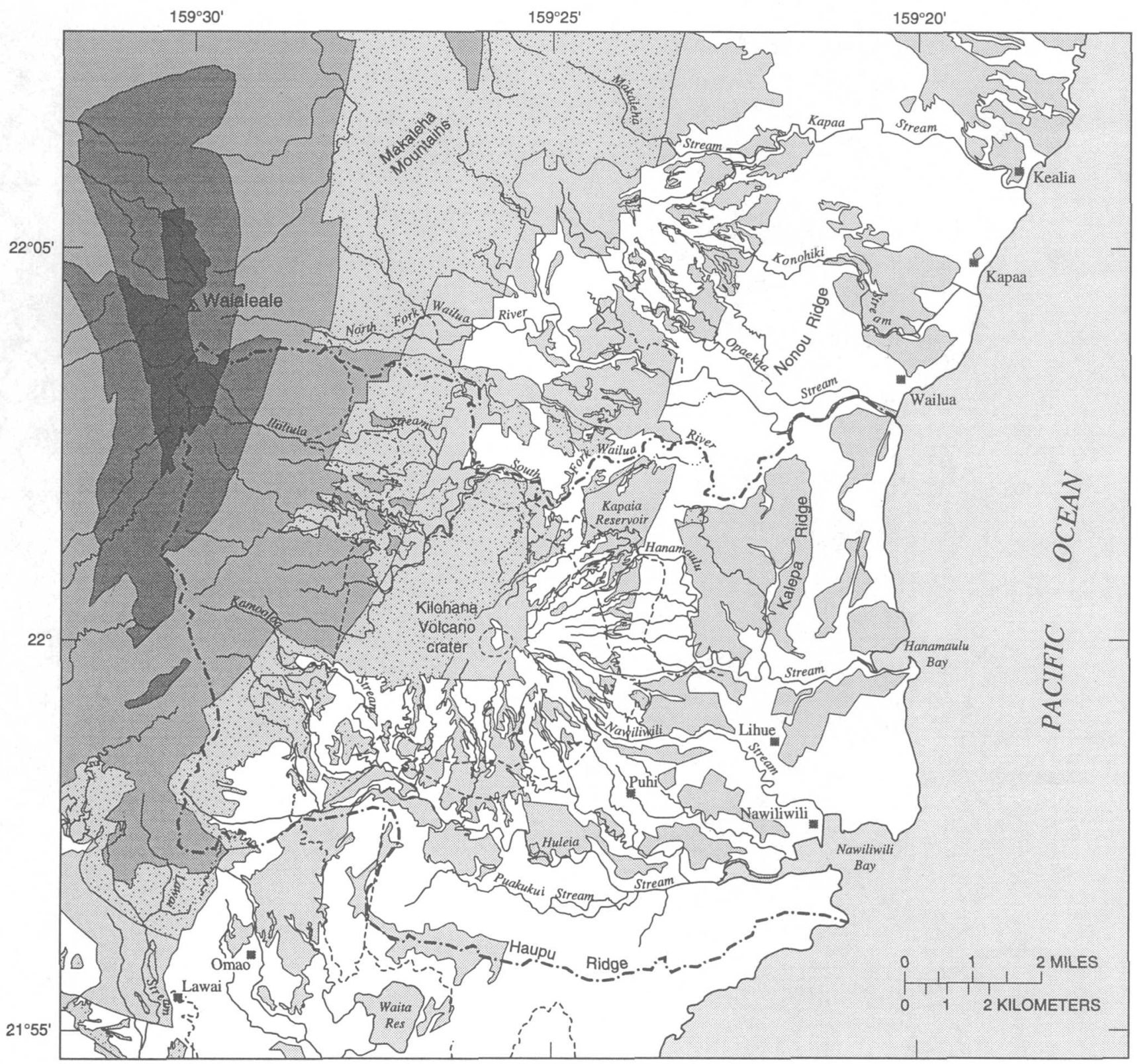

Base modified from U.S. Geological Survey digital data,

1:24,000, 1983, Albers equal area projection, standard

parallels $21^{\circ} 55^{\prime} 40^{\prime \prime}$ and $22^{\circ} 10^{\prime} 20^{\prime \prime}$, central meridian

$159^{\circ} 32^{\prime} 30^{\prime \prime}$

\section{EXPLANATION}

\section{AVERAGE ANNUAL GROUND-WATER RECHARGE, IN INCHES}

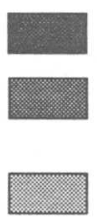

Greater than or equal to 150

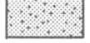

Greater than or equal to 25 and less than 50

Greater than or equal to 100 and less than 150

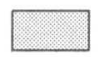

Greater than or equal to 10 and

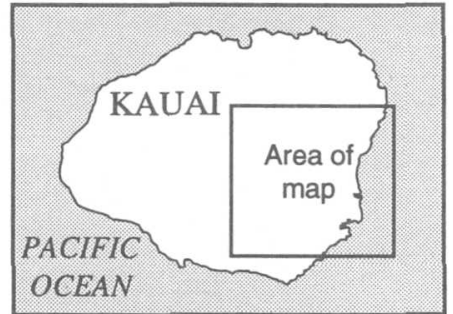

Greater than or equal to 50 and less than 100

less than 25

Less than 10

-.-- BOUNDARY OF THE SOUTHERN LIHUE BASIN

Figure 7. Recharge in the southern Lihue Basin, Kauai, Hawaii (from Shade, 1995a). 


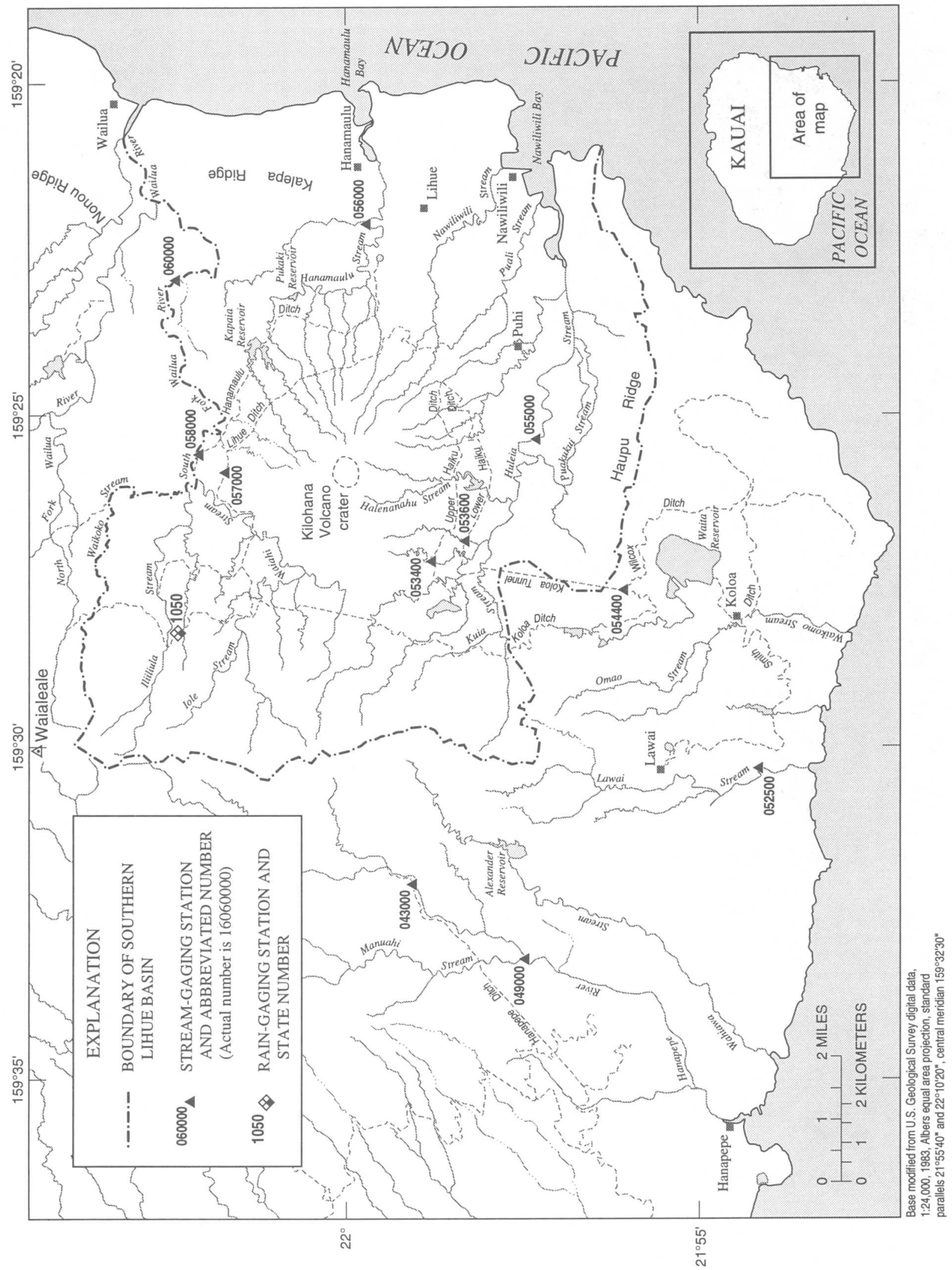

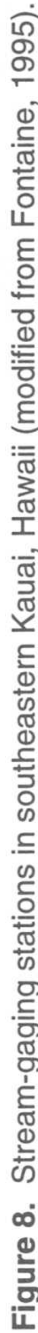


Table 1. Summary of base-flow analyses for selected streams in southeastern Kauai, Hawaii [ $\mathrm{ft}^{3} / \mathrm{s}$, cubic feet per second; na, not applicable. Datum is mean sea level]

\begin{tabular}{|c|c|c|c|c|c|c|}
\hline $\begin{array}{l}\text { Period of } \\
\text { record used in } \\
\text { calculation }\end{array}$ & $\begin{array}{l}\text { Size of window } \\
\text { for base-flow } \\
\text { separation } \\
\text { (days) }\end{array}$ & $\begin{array}{l}\text { Base-flow } \\
\text { index } \\
\text { (percent) }\end{array}$ & $\begin{array}{c}\text { Average annual } \\
\text { base flow } \\
\left(\mathrm{ft}^{3} / \mathrm{s}\right)\end{array}$ & $\begin{array}{c}\text { Average annual } \\
\text { streamflow } \\
\left(\mathrm{ft}^{3} / \mathrm{s}\right)\end{array}$ & $\begin{array}{l}\text { Stream-gaging } \\
\text { stations used in } \\
\text { analysis }\end{array}$ & $\begin{array}{c}\text { Elevation of } \\
\text { stream-gaging } \\
\text { station } \\
\text { (feet) }\end{array}$ \\
\hline \multicolumn{7}{|c|}{ Hanapepe River } \\
\hline $1931-37$ & 4 & 56 & 71.8 & 131.9 & $\begin{array}{l}16049000 \\
16043000\end{array}$ & $\begin{array}{l}222 \\
500\end{array}$ \\
\hline \multicolumn{7}{|c|}{ Lawai Stream } \\
\hline $1963-72$ & 4 & 38 & 2.91 & 8.43 & 16052500 & 37 \\
\hline \multicolumn{7}{|c|}{ Huleia Stream } \\
\hline $1968-70$ & 4 & 48 & 33.4 & 73.4 & $\begin{array}{l}16055000 \\
16053400 \\
16053600 \\
16054400\end{array}$ & $\begin{array}{l}210 \\
470 \\
400 \\
386\end{array}$ \\
\hline \multicolumn{7}{|c|}{ Hanamaulu Stream } \\
\hline $1911-13$ & na & na & 5 to $7^{a}$ & 13 & 16056000 & 90 \\
\hline \multicolumn{7}{|c|}{ South Fork Wailua River } \\
\hline 1913,1918 & 4 & 51 & 115 and $88^{b}$ & 224 and $173^{c}$ & $\begin{array}{l}16060000 \\
16057000 \\
16058000\end{array}$ & $\begin{array}{l}240 \\
550 \\
420\end{array}$ \\
\hline
\end{tabular}

a Estimated on the basis of base-flow index of other analyzed streams in the southern Lihue Basin

${ }^{b}$ Estimated long-term average determined by applying base-flow index to estimate of Davis (1960)

c Estimated long-term average annual flow from Davis (1960)

by Wahl and Wahl (1995). The results of this analysis showed the variability of ground-water discharge to streams over time and a long-term average was computed, but was limited to reaches with sufficiently long gage records. A sampling-window size $(N)$ of 4 days was used in the program for all streams in the study area. The method was developed for unregulated streams, but nearly all of the stream gages in the southern Lihue Basin have upstream diversions. Base flow at a point gaged on a stream can be estimated when there are upstream diversions if the upstream diversions are gaged. The records of the stream and diversions can be added and the composite hydrograph analyzed for base flow. The analysis computed an average base-flow index (percentage of stream flow that is attributed to base flow) and average annual base flow for the stream hydrographs (table 1, fig. 10).

Base flow in the South Fork Wailua River was estimated by summing the records of the Wailua Falls gage (16060000) and records of the upstream diversions at Lihue Ditch (gage 16057000) and Hanamaulu Ditch (gage 16058000) and analyzing the composite hydrograph (smaller ditches above the falls are ungaged, but the sum of their total flows is less than 10 percent of the total flow in the southern Lihue Basin above Wailua
Falls [Davis, 1960]). Base flow could only be determined for water years 1913 and 1918, the only periods during which all three gages were operating. During the 1913 water year, the estimated base flow in the South Fork Wailua River at Wailua Falls was about $100 \mathrm{ft}^{3} / \mathrm{s}$, which is 53 percent of the total average flow $\left(187 \mathrm{ft}^{3} / \mathrm{s}\right)$ in that year. During the 1918 water year, the estimated base flow was $130 \mathrm{ft}^{3} / \mathrm{s}$ which is 50 percent of the 260 $\mathrm{ft}^{3} / \mathrm{s}$ total average flow in that year. The average base flow of the 1913 and 1918 water years is $115 \mathrm{ft}^{3} / \mathrm{s}$ which is 51 percent of the $224 \mathrm{ft}^{3} / \mathrm{s}$ total average flow in those years. To estimate the long-term average base flow, the average base-flow index for 1913 and 1918 (51 percent) was applied to an estimate of total streamflow in the Wailua River by Davis (1960) who analyzed 30 years of plantation ditch data and USGS streamflow data through 1950. After correcting an error in Davis' (1960) estimate where Lower Lihue Ditch flow was doubled, total flow in the South Fork Wailua River is estimated to be $173 \mathrm{ft}^{3} / \mathrm{s}$; applying the 51 percent base-flow index gives a long-term average base-flow estimate of about $88 \mathrm{ft}^{3} / \mathrm{s}$ (table 1 ).

Hanamaulu Stream discharge was recorded for only about 2 years from $1911-13$ at gage 16056000 

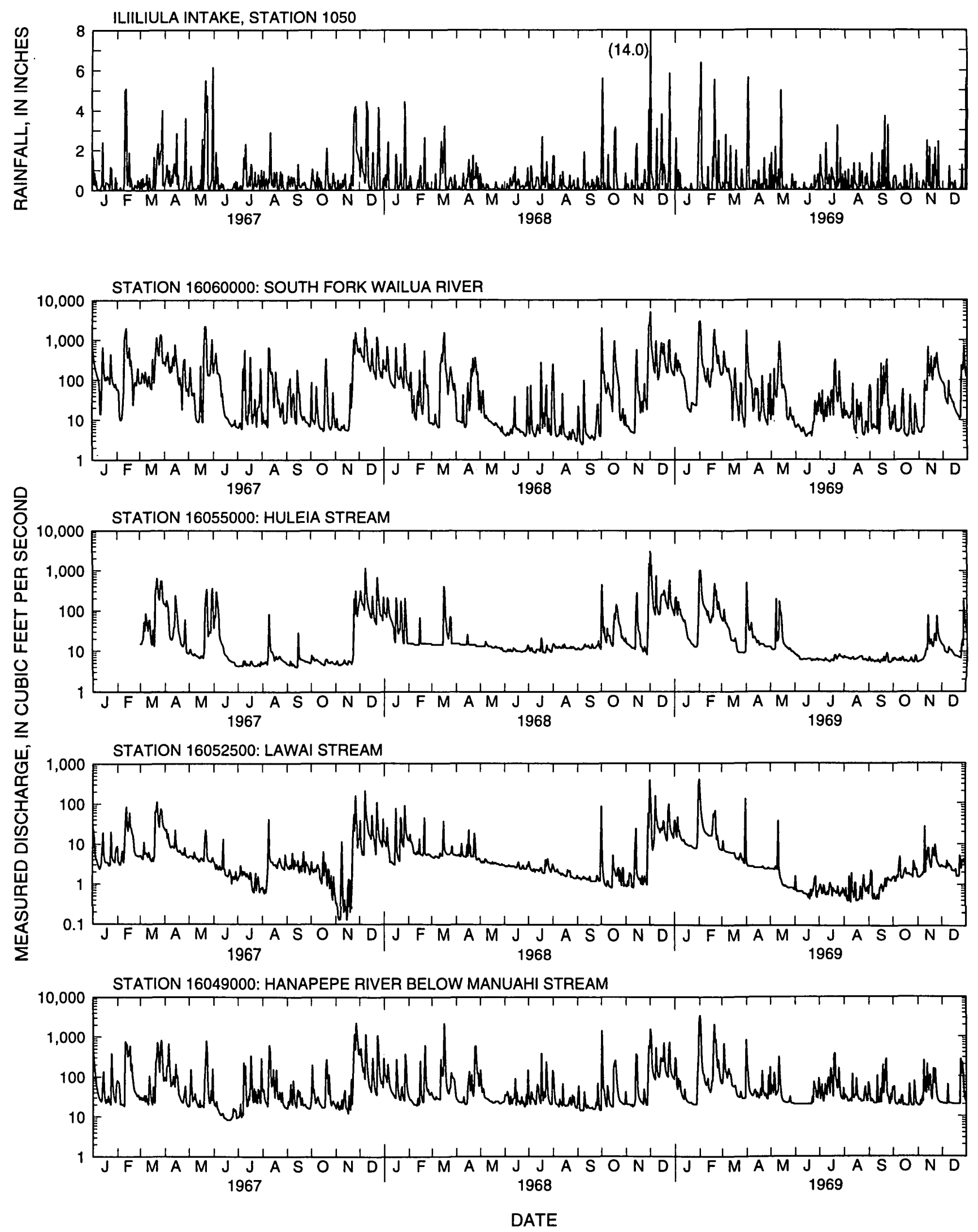

Figure 9. Rainfall and hydrographs for selected continuous stream-gaging stations in southeastern Kauai, Hawaii. 

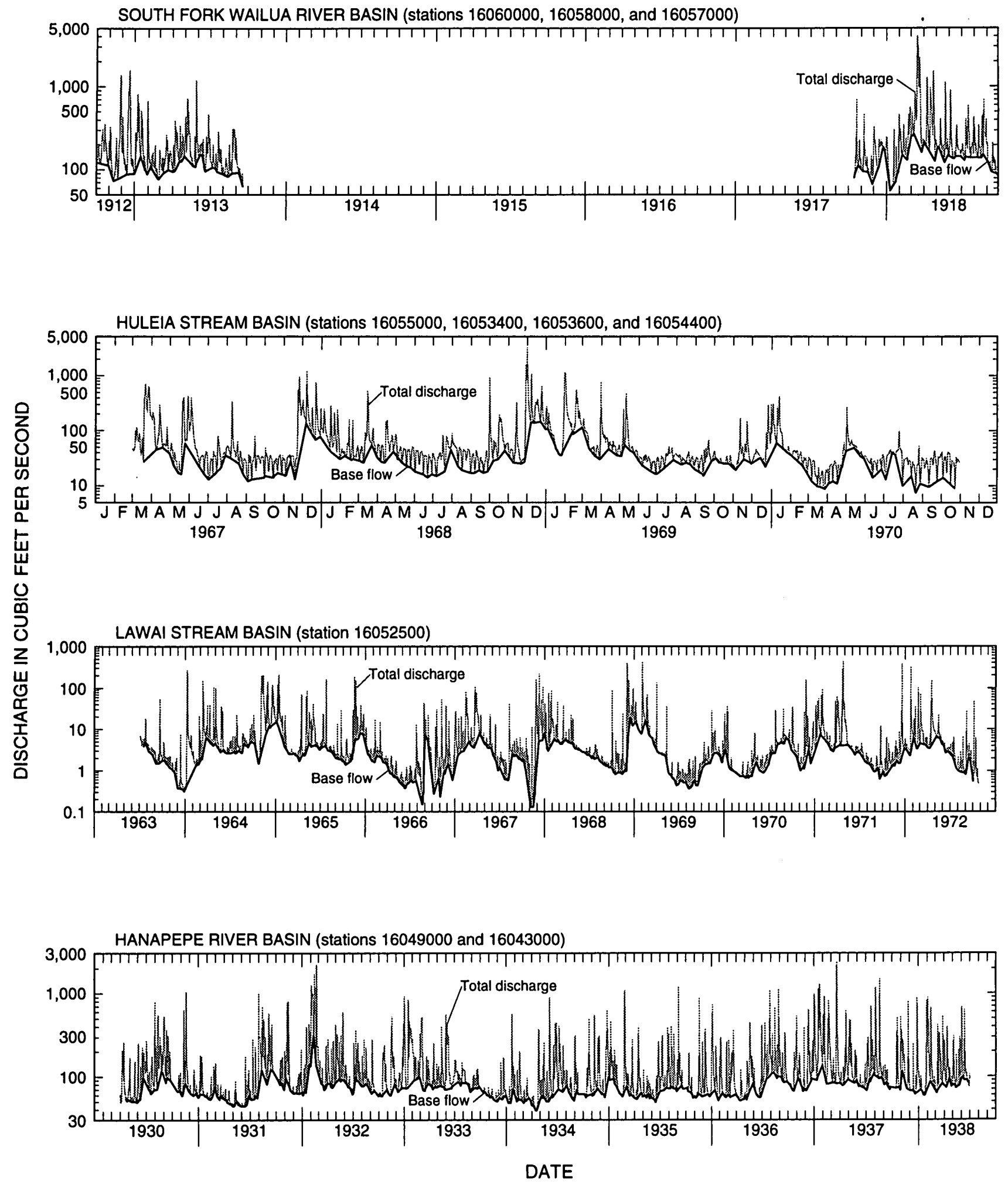

Figure 10. Total discharge and base flow at continuous stream-gaging stations in southeastern Kauai, Hawaii. 
(Martin and Pierce, 1913; Pierce and Larrison, 1914; Larrison, 1915). The average streamflow during this short period of record was about $13 \mathrm{ft}^{3} / \mathrm{s}$. Assuming a base-flow index comparable to similar streams in the study area (38 to 56 percent), an estimate of the base flow of Hanamaulu Stream above the gage during the period of record is 5 to $7 \mathrm{ft}^{3} / \mathrm{s}$. This estimate is probably low because of withdrawals from Kapaia and Pukaki Reservoirs upstream of the gage. Inflows from outside the southern Lihue Basin brought in by the Lihue and Hanamaulu ditches can only enter the Hanamaulu Stream system through Kapaia Reservoir; elsewhere, the ditches are confined to flumes when they cross the channels of Hanamaulu Stream and its tributaries. The net effect of input to Kapaia Reservoir from outside the southern Lihue Basin and withdrawal from the reservoir is not known, but the withdrawal probably exceeds the input from the ditches, because input can be regulated as the reservoir demand dictates (Wilson Okamoto and Associates, 1976). The estimate of 5 to $7 \mathrm{ft}^{3} / \mathrm{s}$ of base flow is thus a minimum. Instantaneous discharge measurements (measured by single field visits, not by continuous gages) made at selected points along Hanamaulu Stream (discussed below) indicate that base flow is higher.

The total flow in Huleia Stream above the gage (16055000) is the sum of the flow measured in the stream plus the amount diverted by the Upper and Lower Haiku ditches, the Koloa Tunnel, and the Koloa Ditch. Base-flow separation analysis could only be done on short periods of concurrent record from the 1960's (table 1). The estimated base flow for Huleia Stream above gage 16055000 , including water diverted through the ditches (gages 16053400, 16053600, and 16054400 ) is $33.4 \mathrm{ft}^{3} / \mathrm{s}$.

These base-flow separation analyses indicate that the total amount of ground water discharging to streams in the southern Lihue Basin is at least $126 \mathrm{ft}^{3} / \mathrm{s}$ or about $81 \mathrm{Mgal} / \mathrm{d}$. Because this estimate does not include ground-water discharge to Nawiliwili or Puali Streams for which there have been no continuous gages, it is probably a minimum. Instantaneous discharge measurements along the channels of these streams (discussed below) indicate substantial ground-water discharge along parts of Nawiliwili Stream.

Base flow was analyzed for Lawai Stream and Hanapepe River outside the Lihue Basin. The average base flow of Lawai Stream at gage 16052500 for 9 years of record between 1963 and 1972 was $2.91 \mathrm{ft}^{3} / \mathrm{s}$ with an unknown volume of water diverted upstream of the gage (table 1). Base flow at Hanapepe River was estimated by summing the records of the Hanapepe River gage (16049000) and records of the upstream diversion at Hanapepe Ditch (gage 16043000) over the concurrent period of record. Base flow diverted to the ditch from the period 1931-37 is estimated to be about $71.8 \mathrm{ft}^{3} / \mathrm{s}$ of a total streamflow of $131.9 \mathrm{ft}^{3} / \mathrm{s}$.

Instantaneous discharge measurements along stream channels.--Ground-water discharge to streams can be studied by measuring instantaneous stream discharge simultaneously at selected points along the course of a stream. An increase in instantaneous discharges between upstream and downstream sites are attributed to ground-water discharge to the stream, a decrease is attributed to stream water infiltrating the ground. The measurements are made during dryweather conditions to ensure that measured streamflow gains are not the result of direct surface runoff. Because the measurements can be made on any accessible point on a stream, no long-term gage data are required, and artificial diversions can be avoided. However, the measurements are only instantaneous measurements of the time-variable exchange of water between the ground and streams.

Records of instantaneous stream discharge measured on selected reaches of the South Fork Wailua River on March 11, 1983 and the North Fork Wailua River on September 21, 1982 were obtained from unpublished USGS files (Hawaii District office). Additional instantaneous stream discharge measurements for this study were made on October 7-10, 1996, on selected reaches of Hanamaulu, Nawiliwili, and Huleia Streams in the southern Lihue Basin, and Lawai Stream and Hanapepe River outside the southern Lihue Basin (fig. 11). For the purposes of comparison, the measured ground-water discharges were divided by the length of stream channel between measurements.

In the North Fork Wailua River, measured gains from ground-water discharge ranged from 0 to $1.5 \times$ $10^{-3} \mathrm{ft}^{3} / \mathrm{s}$ per foot of stream channel (fig. 11). Gains in the South Fork Wailua River, including parts of the Iliiliula, Waikoko, and Waiahi Streams which are tributary to it, ranged from $1.8 \times 10^{-4}$ to $5.0 \times 10^{-4} \mathrm{ft}^{3} / \mathrm{s}$ per foot of stream channel. The total ground-water discharge of all reaches measured on the South Fork Wailua River was $18.7 \mathrm{ft}^{3} / \mathrm{s}$, and of reaches measured 


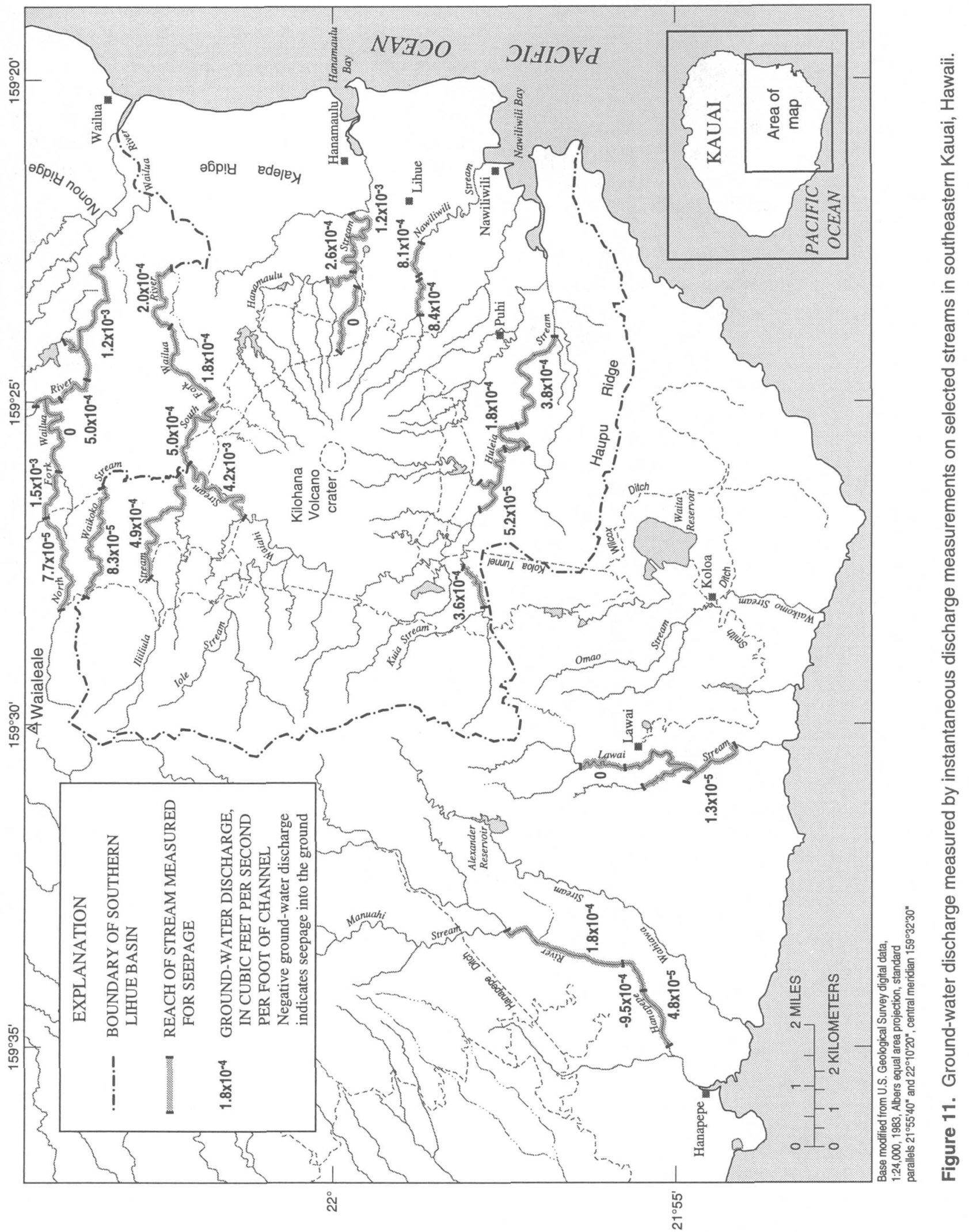


on the North Fork Wailua River was $30.2 \mathrm{ft}^{3} / \mathrm{s}$, but these totals do not include possible ground-water discharge to the lowermost and uppermost reaches of the river.

Only a few reaches of Hanamaulu and Nawiliwili Streams were accessible and free of diversions to allow instantaneous stream-discharge measurements (fig. 11). Measured gains in these streams ranged from 0 to $1.2 \times$ $10^{-3} \mathrm{ft}^{3} / \mathrm{s}$ per foot of stream channel. The total groundwater discharge of all measured reaches was $18.9 \mathrm{ft}^{3} / \mathrm{s}$, but the measured reaches constitute only a fraction of the total length of channels in these streams. If these streams gain from ground-water discharge along most of their reaches as does the Wailua River, then the total ground-water discharge of the streams must be substantially more than $18.9 \mathrm{ft}^{3} / \mathrm{s}$. Although ground-water discharge in the uppermost reaches of Hanamaulu Stream was not measured, on October 10, 1996 flow was observed at about $820-\mathrm{ft}$ elevation where the stream flows through a gap in the rim of the crater of Kilohana Volcano (fig. 11). The flow was estimated to be about 1 $\mathrm{ft}^{3} / \mathrm{s}$, and because it was observed following a long period of dry weather, all of the flow probably originated from ground-water discharge in the crater of Kilohana Volcano.

The reaches measured on Nawiliwili Stream correspond roughly to the reach from which a gain of $3.3 \times$ $10^{-3} \mathrm{ft}^{3} / \mathrm{s}$ per foot of stream channel was measured prior to the construction of the Garlinghouse Tunnel (well 5823-01 [fig. 5]; Macdonald and others, 1960). The tunnel was designed to develop ground water by boring horizontally into the water table. Besides the tunnel, which has been pumped since 1935 , water has been developed from the Kilohana wells about $4,000 \mathrm{ft}$ to the northwest since the 1970's. Comparison of the groundwater discharge measured prior to the Garlinghouse Tunnel and Kilohana wells with the ground-water discharge measured in October 1996 (about $0.8 \times 10^{-3} \mathrm{ft}^{3} / \mathrm{s}$ per foot of stream channel) indicates a decrease in ground-water discharge to the stream of about $2.5 \times$ $10^{-3} \mathrm{ft}^{3} / \mathrm{s}$ per foot of stream channel.

Gains from ground-water discharge measured in Huleia Stream ranged from $5.2 \times 10^{-5}$ to $3.8 \times 10^{-4} \mathrm{ft}^{3} / \mathrm{s}$ per foot of stream channel. The total ground-water discharge to all reaches measured on Huleia Stream was $8.07 \mathrm{ft}^{3} / \mathrm{s}$, but flows in the many unmeasured tributaries draining the south slope of Kilohana Volcano probably have substantial ground-water components, as do Nawiliwili and Hanamaulu Streams.
All but one of the stream reaches measured in the southern Lihue Basin gained from ground-water discharge, including all of the topographically highest reaches measured. Even small streams such as Nawiliwili and Hanamaulu Streams gained substantially from ground-water discharge. This indicates that the water table throughout most of the southern Lihue Basin stands near the ground surface where it is within reach of even shallow stream incision.

Compared to streams in the southern Lihue Basin, measured stream reaches outside the basin gained less from ground-water discharge. The highest gain measured in Hanapepe River was $1.8 \times 10^{-4} \mathrm{ft}^{3} / \mathrm{s}$ per foot of stream channel, which is smaller than the highest gains in even the smaller streams (for example, Hanamaulu and Nawiliwili Streams) within the southern Lihue Basin. Measured gains in Lawai Stream ranged from 0 to $1.3 \times 10^{-5} \mathrm{ft}^{3} / \mathrm{s}$ per foot of stream channel.

\section{Ground-Water Withdrawal}

Ground-water withdrawals in the southern Lihue Basin include pumping from conventional wells and withdrawals from water-development tunnels that are bored horizontally into the water table near gaining streams. In the mass balance of water in an aquifer, withdrawal from wells and tunnels represents a component of ground-water discharge because withdrawal removes water from the aquifer as does ground-water discharge to streams and the ocean. However, whereas ground-water discharge to streams and the ocean are natural and, except for minor seasonal variations, have established an equilibrium over many thousands of years, withdrawals from wells and tunnels are artificial and upset the natural equilibrium. Effects from withdrawals within the Lihue Basin may spread beyond the topographic boundaries of the basin, and effects of withdrawals from outside the basin may affect groundwater in the basin. For this reason, ground-water withdrawal from not only within the southern Lihue Basin, but in the adjacent area to the southwest of Haupu Ridge to the Hanapepe River, was studied. Ground-water withdrawal from the area to the north is relatively small. These withdrawals are unlikely to affect the southern Lihue Basin because the propagation of the cones of depression will be halted by the large amount of water available (through induced recharge or reduced groundwater discharge) in the Wailua River. 
Accounting for ground-water withdrawal from the southern Lihue Basin is difficult, however, because many wells are not metered. Shade (1995b) used records of water use (the water delivered to customers) which were more complete than withdrawal records, and applied a conveyance-loss factor of 15 percent to compute an average ground-water withdrawal estimate of $46.29 \mathrm{Mgal} / \mathrm{d}$ for Kauai in 1990. Shade's estimate does not show how the withdrawal is distributed within the southern Lihue Basin, and does not reflect the higher withdrawal prior to 1990 (when sugar plantations were more active) which may still have lingering effects on the ground-water system.

Most of the ground-water withdrawal data for this study were acquired from the State of Hawaii Commission on Water Resource Management (Water Commission). Although the Water Commission data are the most complete ground-water withdrawal data available for Kauai, many wells had no meters and therefore no withdrawal records. The Water Commission records represent only about 70 percent of known pumped wells (Neal Fujii, Water Commission, oral commun., 1993).

A total of 35 wells in the area from the Wailua River to Hanapepe River had withdrawals reported at the Water Commission as of 1993 . The reported withdrawals were averaged over their periods of record through early 1993 (table 2). Average withdrawals for two wells (5530-02 and 5529-03) that were not in the Water Commission data were obtained from the Water Commission's well index and USGS well files. The total ground-water withdrawal reported for well fields in the southern Lihue Basin is about $4 \mathrm{Mgal} / \mathrm{d}$. The largest withdrawals within the southern Lihue Basin come from the Kilohana-Puhi well field (table 2) which accounts for 66 percent of the reported withdrawal. Ground-water withdrawal from Lihue Town well field accounts for 13 percent, Kokolau Tunnel (well 572501 ) in the Haiku well field accounts for about 15 percent, and withdrawal from Wailua accounts for about 6 percent of the total ground-water withdrawal in the southern Lihue Basin. About $27 \mathrm{Mgal} / \mathrm{d}$ is withdrawn from the area outside the southern Lihue Basin between Haupu Ridge and Hanapepe River. Wells in Koloa account for 27 percent of the reported withdrawal in this area, wells in the Lawai area account for 22 percent and Hanapepe account for 51 percent.

The total reported ground-water withdrawal from the area between the Wailua River and the Hanapepe
River is about $30 \mathrm{Mgal} / \mathrm{d}$ which is twice the withdrawal estimated for the same area for 1990 by Shade (1995b). Most of the difference between withdrawal estimates in this report and the estimate by Shade (1995b) is in the Hanapepe area. Some of the withdrawal reported for the large agricultural well 5534-01 in the Hanapepe River valley comes from surface water taken directly from the river (Macdonald and others, 1960) but the proportion of ground water to surface water is not known. Shade (1995b) assumed all of the withdrawal from well 553401 to be surface water. If the withdrawal from well 5534-01 is excluded from the ground-water withdrawal total, the ground-water withdrawal in this report is about $2 \mathrm{Mgal} / \mathrm{d}$ higher than Shade's (1990b) estimate. The higher withdrawal estimate in this report probably results from averaging withdrawal over the entire period of record, including the long period when agricultural ground-water use was high, whereas Shade's (1995b) estimate is for 1990 only, after agricultural ground-water withdrawal for sugarcane production had decreased. Agricultural ground-water use on Kauai in 1990 was only 36 percent of agricultural ground-water use in 1980; total ground water used in 1990 was only 50 percent of total ground water used in 1980 (Shade, 1995b).

\section{Ground-Water Discharge to the Ocean}

No practical or reliable method currently exists for directly measuring the amount of ground water that discharges from the aquifer directly into the ocean. Most ground-water discharge probably seeps diffusely from the ocean floor and quickly mixes with seawater. An imprecise estimate can be made by assuming that the southern Lihue Basin is a closed system where no ground water enters from adjacent ground-water areas and ground water exits only by ground-water withdrawal and stream and coastal discharge. With this simplifying assumption, the only source of ground-water inflow comes from surface recharge to the southern Lihue Basin, and ground-water discharge to the ocean can be estimated by subtracting ground-water discharge to streams and well withdrawals from recharge.

The total recharge in the southern Lihue Basin, calculated from Shade's (1995a) estimate, is about 130 $\mathrm{Mgal} / \mathrm{d}$. This total includes not only the recharge entering within the limits of the southern Lihue Basin as defined in this report, but also the area between the North Fork Wailua River and the South Fork Wailua 
Table 2. Reported withdrawals from wells in southeastern Kauai, Hawaii

[Withdrawal averaged over period of record through December 1993, for each well. Data from the Hawaii State Commission on Water Resource Management, 1993, unpub., except where noted]

\begin{tabular}{|c|c|c|c|}
\hline State well number & Well name & $\begin{array}{c}\text { Average withdrawal } \\
\text { (million gallons per day) }\end{array}$ & $\begin{array}{l}\text { Period of record used for } \\
\text { average withdrawal }\end{array}$ \\
\hline \multicolumn{4}{|c|}{ Wailua well field } \\
\hline $0321-01$ & Nonou 9-1C & 0.24 & December 1987 - February 1993 \\
\hline \multicolumn{4}{|c|}{ Kilohana and Puhi well field } \\
\hline $5923-05$ & Kilohana G & 0.19 & November 1988 - January 1993 \\
\hline $5923-01,02,03,04,07$ & Kilohana A, B, C, F, I & 1.20 & November 1988 - January 1993 \\
\hline $5824-03$ & Puhi 2 & 0.03 & November 1987 - January 1993 \\
\hline $5824-01$ & Puhi 1 & 0.07 & November 1987 - January 1993 \\
\hline $5823-01$ & Garlinghouse Tunnel & 1.07 & November 1987 - January 1993 \\
\hline \multicolumn{4}{|c|}{ Haiku well field } \\
\hline $5725-01$ & Kokolau Tunnel & 0.58 & November 1987 - January 1993 \\
\hline \multicolumn{4}{|c|}{ Lihue Town well field } \\
\hline $5821-04$ & Westin 2 & 0.12 & May 1989 - March 1993 \\
\hline $5821-0$ & Westin 1 & 0.09 & May 1989 - March 1993 \\
\hline $5820-01$ & Westin 3 & 0.11 & May 1989 - March 1993 \\
\hline $5822-01$ & Sugar Mill & 0.03 & December 1982 - June 1992 \\
\hline $5822-02$ & Lihue Grammar School & 0.07 & November 1987 - January 1993 \\
\hline $5821-06$ & Westin 5 & 0.09 & October 1992 - March 1993 \\
\hline \multicolumn{4}{|c|}{ Koloa well field } \\
\hline $5526-01$ & Kaluahonu (K-32) & $0 . \overline{66}$ & December 1982 - June 1992 \\
\hline $5523-01$ & Kipu Kai & 0.01 & December 1982 - November 1991 \\
\hline $5523-02$ & Kipu Kai & 0.16 & December 1982 - December 1991 \\
\hline $5527-01$ & Kahaono & 1.10 & December 1983 - December 1987 \\
\hline $5425-11$ & Mahaulepu 11 & 0.96 & January 1983 - June 1992 \\
\hline $5427-01$ & Koloa A & 0.23 & December 1987 - February 1993 \\
\hline $5427-02$ & Koloa B & 0.47 & December 1987 - February 1993 \\
\hline $5426-03$ & Koloa & 2.44 & December 1982 - June 1992 \\
\hline $5426-04$ & Koloa C & 0.63 & April 1988 - February 1993 \\
\hline $5426-05$ & Koloa D & 0.62 & April 1988 - February 1993 \\
\hline \multicolumn{4}{|c|}{ Lawai well field } \\
\hline $5631-01$ & Kalaheo A & 0.31 & December 1987 - February 1993 \\
\hline $5631-02$ & Kalaheo B & 0.14 & January1990 - February 1993 \\
\hline $5530-02$ & Lawai Cannery & $0.9^{\mathrm{a}}$ & not available ${ }^{\mathrm{a}}$ \\
\hline $5530-03$ & Lawai 1 & 0.12 & July 1990 - February 1992 \\
\hline $5530-04$ & Lawai 2 & 0.27 & May 1990 - February 1993 \\
\hline $5529-01$ & Huinawai Reservoir & 2.31 & December 1982 - June 1992 \\
\hline $5529-03$ & Lawai A & $1.73^{\mathrm{b}}$ & January 1990 - December 1990 \\
\hline \multicolumn{4}{|c|}{ Hanapepe well field } \\
\hline $5533-01$ & Hanapepe A & 0.15 & November 1987 - January 1993 \\
\hline $5533-02$ & Hanapepe B & 0.05 & November 1987 - September 1991 \\
\hline $5534-01$ & Hanapepe Tunnel Pump 3 & $13.24^{\mathrm{c}}$ & December 1982 - June 1992 \\
\hline $5534-03$ & Hanapepe Town & 0.01 & November 1987 - January 1993 \\
\hline
\end{tabular}

a Average reported in Hawaii State Commission on Water Resource Management unpub. index of wells, 1997 ; no period of record for the average was specified

b From U.S. Geological Survey unpub. files, Honolulu, Hawaii

c Unknown portion of reported withdrawal comes from surface water 
River because some of the recharge in this area may contribute to ground-water discharge at streams (particularly the South Fork Wailua River) in the southern Lihue Basin. The recharge is probably slightly overestimated because not all of the water recharging the area between the forks flows to the southern Lihue Basin; some water flows north. Subtracting ground-water discharge to streams (at least $81 \mathrm{Mgal} / \mathrm{d}$ ) and ground-water withdrawal from wells (about $4 \mathrm{Mgal} / \mathrm{d}$ ) leaves 44 $\mathrm{Mgal} / \mathrm{d}$, which represents an overestimate of the water available to flow to the ocean. Not all of this remaining ground water will flow to the ocean. Part of this ground water probably flows out of the southern Lihue Basin to the south through Haupu Ridge and although some of this water will reach the ocean at the southern coast, an unknown amount may seep to streams or be withdrawn by wells outside the southern Lihue Basin. Also, the assumption of a closed system is not valid. Because the cones of depression from ground-water withdrawals in the southern Lihue Basin may have extended beyond its boundaries, some portion of the $4 \mathrm{Mgal} / \mathrm{d}$ of the reported ground-water withdrawal may come from outside the southern Lihue Basin. The amount of flow to the ocean must therefore be less than $44 \mathrm{Mgal} / \mathrm{d}$, but exactly how much less cannot be quantified by this approach.

Although the water-budget approach is imprecise, it indicates ground-water discharge to the ocean is small relative to ground-water discharge to streams. Of the natural and artificial means by which ground water discharges from the aquifer in the southern Lihue Basin, ground-water discharge to streams predominates over ground-water discharge to the ocean and well withdrawal. At least 62 percent of recharge is eventually discharged to streams whereas less than 34 percent discharges directly to the ocean. The remainder is withdrawn from wells.

\section{Ground-Water Levels}

Water-level elevations in wells are near sea level at the coast but increase steeply with distance inland. Water levels in the monitor wells drilled by the Kauai DOW/USGS cooperative study ranged from $250 \mathrm{ft}$ elevation at well 5923-08 which is located $3.2 \mathrm{mi}$ from the coast, to $576 \mathrm{ft}$ elevation at well 0126-01 which is located $6 \mathrm{mi}$ from the coast (Gingerich and Izuka, 1997a; Izuka and Gingerich, 1997a). Water levels in these wells remained hundreds of feet above sea level even when the wells had penetrated several hundred feet below sea level. Other wells drilled to sea level in the southern Lihue Basin, including 5822-02, 5824-06, 5824-09, and 5923-01, had water levels ranging from 190- to 360-ft elevation, which indicates that the high water levels are part of a ground-water system that is completely saturated below the water table.

Although water levels in these wells remained hundreds of feet above sea level, most wells showed water-level declines of a few feet as they were deepened. Water levels in other wells declined by as much as $200 \mathrm{ft}$ during drilling. These water-level declines during drilling indicate that vertical head gradients exist in the aquifer. The effect of these vertical head gradients may be so great that the thickness of the freshwater body cannot be accurately estimated by the GhybenHerzberg principle.

Vertical head gradients in the Koloa Volcanics.-Observed water levels declined during the drilling of many of the wells in the Kilohana, Puhi, Lihue Town, and Haiku well fields (figs. 5 and 12). Two abrupt water-level drops within the Koloa Volcanics can be correlated between these well fields. When wells penetrated through the top feature, observed water levels dropped 30 to $75 \mathrm{ft}$; a second abrupt drop of about 80 to $200 \mathrm{ft}$ was observed during drilling of wells 5824-04, 5824-09, 5822-02, and 5923-01. Initial water levels during drilling of wells in the Haiku and Puhi well fields were between 370 and $430 \mathrm{ft}$ elevation. In the Kilohana wells, where the ground surface is lower, initial water levels were between 190 and $320 \mathrm{ft}$. Water levels dropped abruptly to between 340-ft and 390-ft elevation when wells in the Haiku and Puhi well fields penetrated to about 250-ft elevation and when wells in the Kilohana well field penetrated to between 150 to $200 \mathrm{ft}$. Water levels again dropped abruptly to between 50 and $70 \mathrm{ft}$ elevation when wells in both well fields penetrated to about 0 to -200-ft elevation. The stepwise water-level drops indicate that the wells penetrated multiple layers, each having a different permeability. An abrupt decline in water level indicates that the well penetrated into a layer with a lower head resulting from a higher permeability and a better connection to a discharge area such as a stream or the ocean. The only deep well near the Kilohana well field that did not show the second drop in water level is well 5923-08, where water levels remained at over $200-\mathrm{ft}$ elevation even when the well penetrated to -730 -ft elevation. 


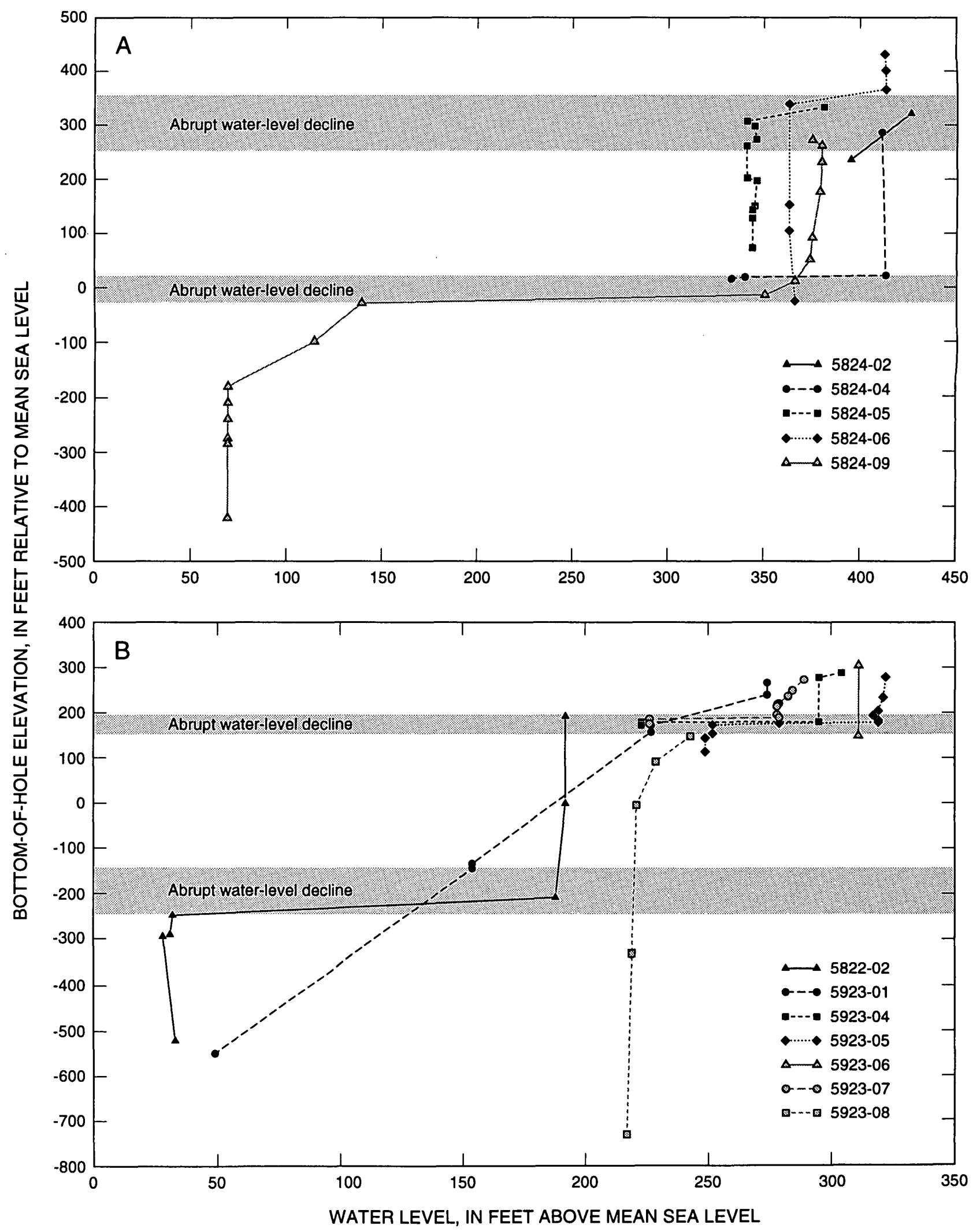

Figure 12. Water levels compared with depth of drilling for selected wells in the A, Haiku and Puhi; and $B$, Kilohana and Lihue Town well fields, Kauai, Hawaii. 
The abrupt drops in water levels correlate with changes in lithology within the Koloa Volcanics noted in the drilling logs for four of the wells (fig. 13). Both the upper and lower water-level drops are correlative with transitions from thick sections of dense lava rock above to loosely consolidated rock below. The underlying loosely consolidated rock apparently has a highhorizontal-permeability connection to a discharge zone which allows water to move more freely horizontally and lowers pressure head at this depth in the aquifer. The vertical permeability of the thick, dense lava rock is apparently very low. Sustained withdrawal at 900 $\mathrm{gal} / \mathrm{min}$ for 10 days at well 5824-09 produced no measurable drawdown in well 5824-02 which was only 78 $\mathrm{ft}$ away horizontally, but whose open interval was separated vertically from the open interval of the pumped well by about $250 \mathrm{ft}$ of thick lava flows.

Macdonald and others (1960) describe a red clay perching layer at an elevation of about $183 \mathrm{ft}$ near the Garlinghouse Tunnel (well 5823-01), but there is little evidence that the clay layer causes the abrupt waterlevel drop in the wells. A possibly correlative brown clay layer at an elevation of 172 to $151 \mathrm{ft}$ was described in the drilling log from well 5923-01, but the abrupt water-level decline in this well correlates not with penetration through the clay, but through a thick, dense, rock layer, as in the other wells in the Kilohana, Puhi, and Haiku well fields.

The multi-layered aquifer apparently has limited northern and western extents, but how far it extends to the east and south is unknown (fig. 14). The multilayered aquifer does not extend as far as well 5923-08 in which no abrupt water-level decline was observed even when the well was drilled to an elevation of -730 $\mathrm{ft}$. One abrupt water-level decline was measured as far to the southwest as well 5824-06 (the well probably did not penetrate deep enough to reach the lower abrupt water-level decline), but farther to the west, at well 5825-01, no abrupt water-level declines were recorded even though the well penetrated to an elevation of -134 $\mathrm{ft}$. An abrupt water-level decline was observed as far east as well 5821-01 at an elevation of about $-100 \mathrm{ft}$, but data for wells farther eastward (closer to the coast) are inconclusive. There are no deep wells to the southeast, toward Huleia Stream.

Although water levels in wells drilled by the Kauai DOW/USGS cooperative study in the northern part of the southern Lihue Basin did not decline abruptly as in wells in the Kilohana and Puhi well fields, water levels at the completion of drilling in all but one of the wells were lower than the first water levels encountered during drilling, which indicates a gradual decline in water levels with depth. This downwarddecreasing head gradient is probably related to downward movement of water as recharge reaches the water table and descends into the freshwater body (fig. 6).

\section{Horizontal head gradients in the Koloa Volca-} nics.--Horizontal head gradients in the southern Lihue Basin cannot be studied by simply comparing water levels in completed wells. Because of substantial vertical head gradients in some areas, water levels of completed wells may not represent the water table, but an average head through the part of the aquifer penetrated by the well. Only the first water level observed during drilling, when the well penetrates only a short distance into the aquifer, closely represents the water table. This information was gathered for as many of the wells in the southern Lihue Basin as were available (table 3 ) and used to construct the water-table map and profile in figure 15. Because these water levels were measured over several decades, short-term variations caused by factors such as ground-water development, irrigation, or reservoir seepage may not be accurately represented. These variations are probably localized and small, relative to the high heads and horizontal gradients that characterize the southern Lihue Basin. Thus, although the watertable map does not represent any instant in time, it provides a view of the regional water table generalized over time.

In addition to the well data, the elevations of springs and marshes shown on topographic maps were used to contour the water-table map. These areas of ground-water discharge indicate places where the water table intersects the ground surface. Many of the marsh locations were determined from the topographic maps of Kauai that were prepared in 1910 and used as the base for the geologic map of Macdonald and others (1960). Other information came from unpublished USGS records that indicate that some reservoirs were sited in marshy areas.

The instantaneous stream-discharge measurements and base-flow analyses also were used to construct the water-table map. Instantaneous stream-discharge measurements and base-flow analyses indicate that the streams on the flanks of the Kilohana Volcano are perennial because they gain from ground-water 


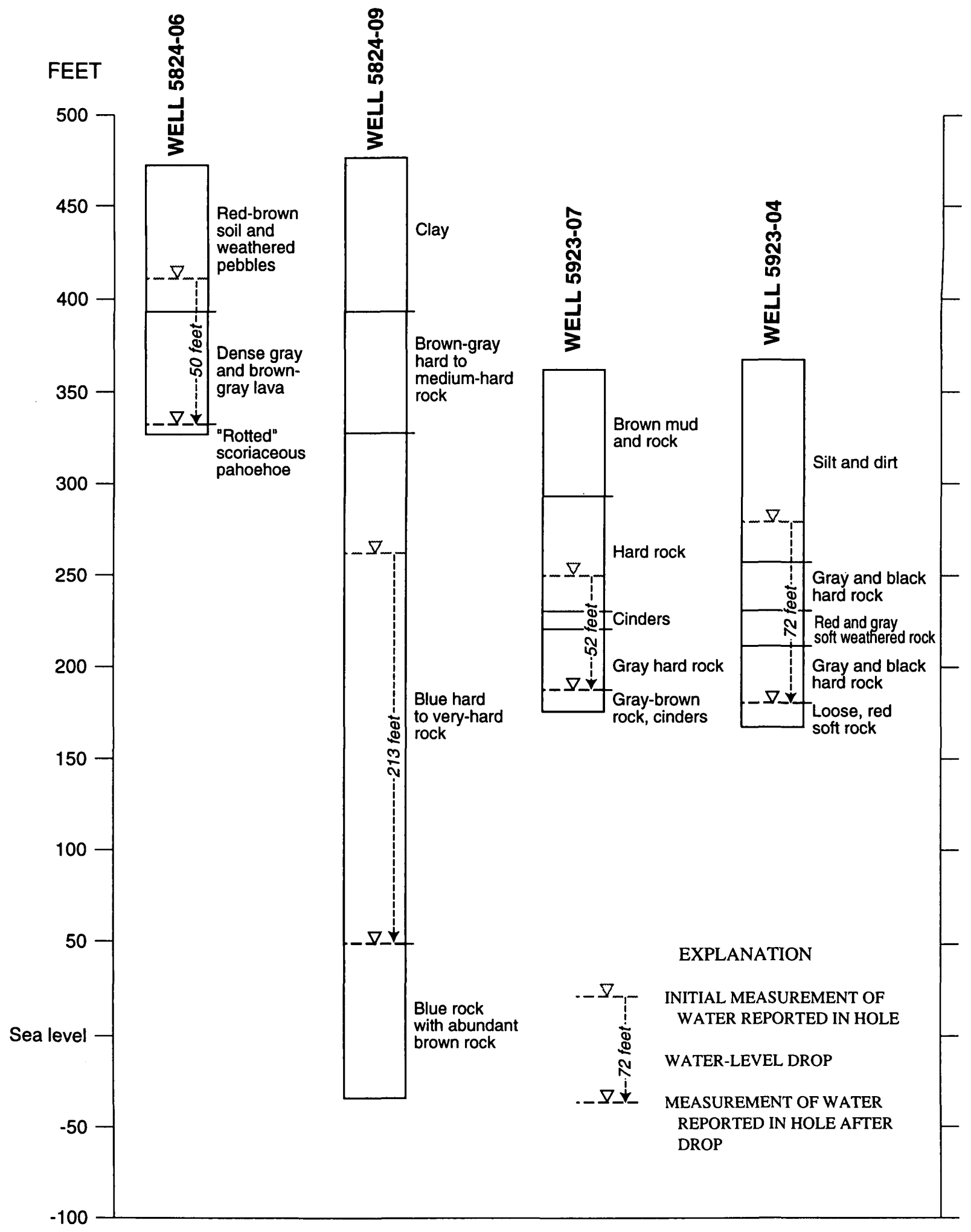

Figure 13. Correlation of abrupt water-level declines with driller's logs from selected wells in the southern Lihue Basin, Kauai, Hawaii. 


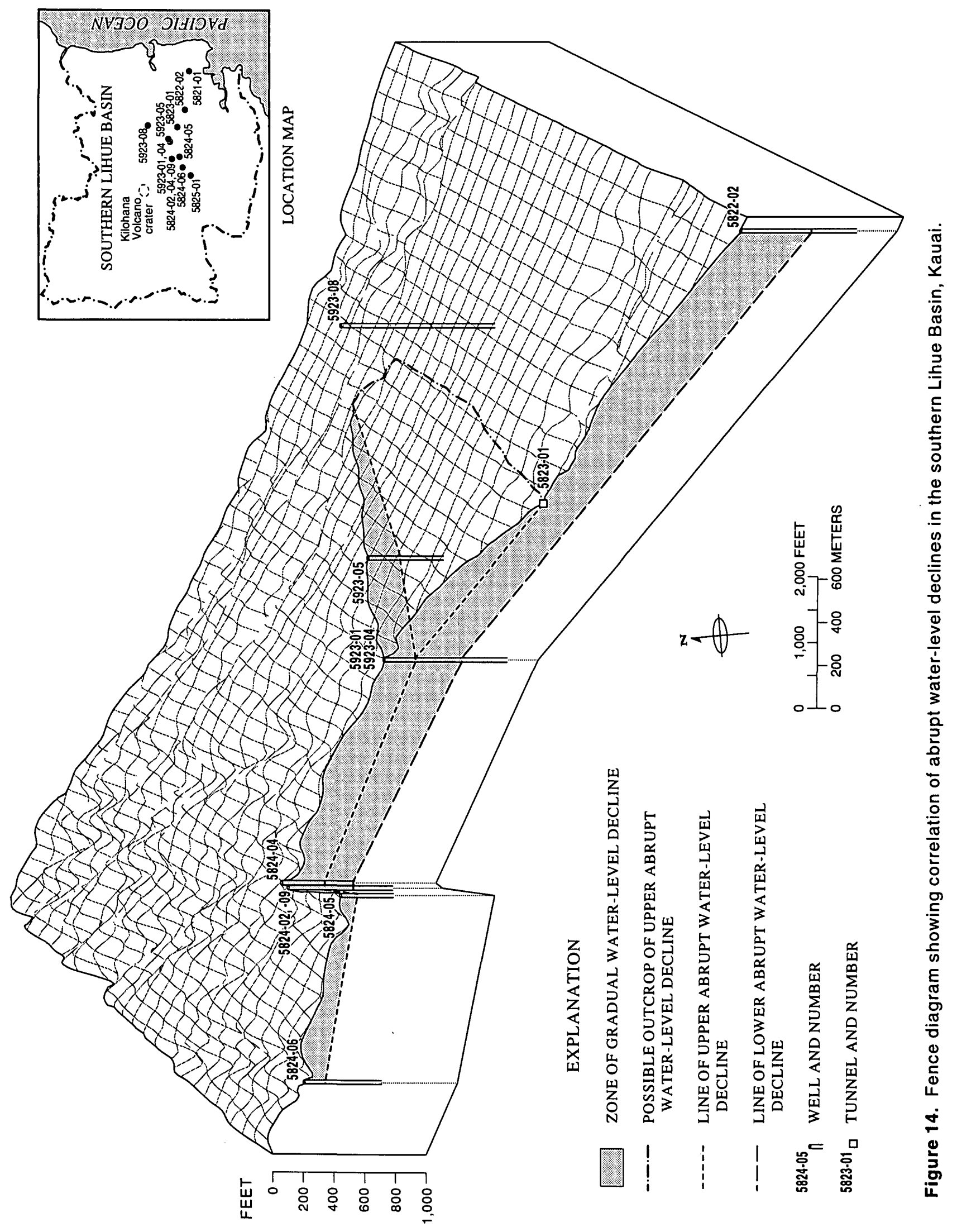


Table 3. Water-level information used to construct the generalized water-table map, southern Lihue Basin, Kauai, Hawaii [ft, feet; --, not available; na, not applicable; obs, observation; all water-level measurements refer to the first water level measured during drilling of the well unless otherwise noted; all well information is from unpublished data, USGS, Hawaii District well files unless otherwise noted. Datum is mean sea level]

\begin{tabular}{|c|c|c|c|c|c|c|}
\hline \multirow[b]{2}{*}{$\begin{array}{l}\text { State well number or } \\
\text { map designation } \\
\text { (fig. 5) }\end{array}$} & \multirow[b]{2}{*}{ Well name } & \multicolumn{5}{|c|}{ Well characteristics at time of water-level measurement } \\
\hline & & $\begin{array}{l}\text { Ground } \\
\text { elevation } \\
\text { (ft) }\end{array}$ & $\begin{array}{l}\text { Elevation of top } \\
\text { of open interval } \\
\text { (ft) }\end{array}$ & $\begin{array}{l}\text { Elevation of } \\
\text { bottom of open } \\
\text { interval (ft) }\end{array}$ & $\begin{array}{c}\text { Water level } \\
\text { (ft) }\end{array}$ & $\begin{array}{c}\text { Date of } \\
\text { water-level } \\
\text { measurement }\end{array}$ \\
\hline $0221-01$ & Fern Grotto 1 & 17 & -18 & -43 & $\overline{5^{a}}$ & $2 / 24 / 87$ \\
\hline 0124-01 & Northeast Kilohana & 466 & 466 & 305 & 428 & $6 / 13 / 95^{b}$ \\
\hline $0126-01$ & Northwest Kilohana & 678 & 480 & 431 & 576 & $1 / 9 / 96^{c}$ \\
\hline $0020-01$ & Hanamaulu Shaft 2 & 10 & 10 & -1 & 3 & $-\cdot$ \\
\hline $0023-01$ & Pukaki Reservoir & 319 & 163 & -3 & $254^{e}$ & $3 / 7 / 96$ \\
\hline $5923-01$ & Kilohana A & 371 & 371 & 239 & 274 & $6 / 73$ \\
\hline $5923-03$ & Kilohana C & 362 & 362 & 197 & 300 & $1 / 27 / 78$ \\
\hline $5923-04$ & Kilohana F & 369 & 368 & 288 & 304 & $4 / 10 / 80$ \\
\hline 5923-05 & Kilohana G & 384 & 372 & 279 & 322 & $6 / 5 / 81$ \\
\hline $5923-06$ & Kilohana H & 393 & 383 & 295 & 311 & $8 / 18 / 81$ \\
\hline $5923-07$ & Kilohana I & 363 & 353 & 258 & 289 & $11 / 27 / 81$ \\
\hline $5923-08$ & Hanamaulu & 272 & 256 & 148 & 250 & $4 / 19 / 95^{f}$ \\
\hline $5821-01$ & Lihue STP & 121 & 121 & 76 & 115 & $5 / 7 / 74$ \\
\hline $5822-02$ & Grammar School & 224 & 211 & 124 & 192 & $5 / 10 / 618$ \\
\hline $5823-01$ & Garlinghouse Tunnel & 205 & na & 187 & 205 & $1935^{d}$ \\
\hline $5824-01 \mathrm{M}$ & Puhi obs 1 & 453 & 408 & 374 & 401 & $1 / 92$ \\
\hline $5824-02$ & Kilohana D & 488 & 484 & 319 & 426 & $2 / 24 / 79$ \\
\hline $5824-03$ & Kilohana E & 408 & 389 & 320 & 340 & $4 / 28 / 80$ \\
\hline 5824-04 & Kilohana J & 484 & 477 & 270 & 411 & $4 / 14 / 82$ \\
\hline $5824-05$ & Puhi 3 & 411 & 403 & 321 & 381 & $11 / 8 / 89$ \\
\hline $5824-06$ & Puhi 4 & 473 & 473 & 406 & 406 & $7 / 92$ \\
\hline 5824-07 & Puhi obs 3 & 475 & 420 & 210 & 350 & -- \\
\hline 5824-09 & Puhi 5 & 481 & 400 & 376 & 385 & $11 / 21 / 95$ \\
\hline $5825-01$ & Haiku Mauka 1 & 459 & 459 & -134 & $335^{a}$ & $12 / 28 / 93$ \\
\hline $5825-01 \mathrm{M}$ & Puhi obs 2 & 489 & 371 & 289 & 344 & $1 / 27 / 92$ \\
\hline $5825-02$ & Puhi obs 4 & 470 & 470 & 25 & 310 & -- \\
\hline $5825-03$ & Puhi obs 5 & 465 & 465 & 20 & 330 & -- \\
\hline $5721-01$ & Westin Kauai & 23 & -42 & -302 & $9^{a}$ & $10 / 23 / 86$ \\
\hline $5725-01$ & Kokolau Tunnel & 300 & na & na & 300 & $1928^{d}$ \\
\hline $5626-01$ & Puakukui & 484 & 228 & 26 & 173 & $11 / 22 / 95^{\mathrm{h}}$ \\
\hline $5727-01$ & Koloa H-34 & 508 & -- & -- & $423^{a}$ & $3 / 14 / 73$ \\
\hline HH MW3 & Halehaka MW3 & 220 & -- & -- & $159^{a}$ & -- \\
\hline $\mathrm{TH} \mathrm{C}$ & Test hole C & 284 & 284 & 73 & $227^{\mathrm{a}, \mathrm{i}}$ & -- \\
\hline TH F & Test hole F & 325 & 325 & 171 & $258^{\mathrm{a}, \mathrm{i}}$ & -- \\
\hline TH I & Test hole I & 353 & 353 & -- & $263^{a, i}$ & -- \\
\hline TH J & Test hole J & 380 & 380 & -- & $230^{\mathrm{a}, \mathrm{i}}$ & -- \\
\hline $\mathrm{T} 1$ & unnamed tunnel & 600 & na & na & $600^{j}$ & -- \\
\hline Quarry & na & na & na & na & $470^{k}$ & $10 / 11 / 96$ \\
\hline Kilohana Volcano crater & na & na & na & na & $820^{1}$ & $10 / 9 / 96$ \\
\hline
\end{tabular}

a Water level measured after well was completed

b Izuka and Gingerich, 1997b

c Gingerich and Izuka, 1997a

d year that tunnel was installed

e Izuka and Gingerich, 1997c; first water level measured after well was drilled below sea level

I Izuka and Gingerich, 1997a

g Department of Land and Natural Resources, 1962

h Gingerich and Izuka, 1997b

i PBR Hawaii, 1994

jMacdonald and others, 1960

k Estimated from topographic contours on the U.S. Geological Survey 1:24,000-scale Koloa Quadrangle map (1983)

${ }^{1}$ Estimated from topographic contours on the U.S. Geological Survey 1:24,000-scale Waialeale Quadrangle map (1983) 


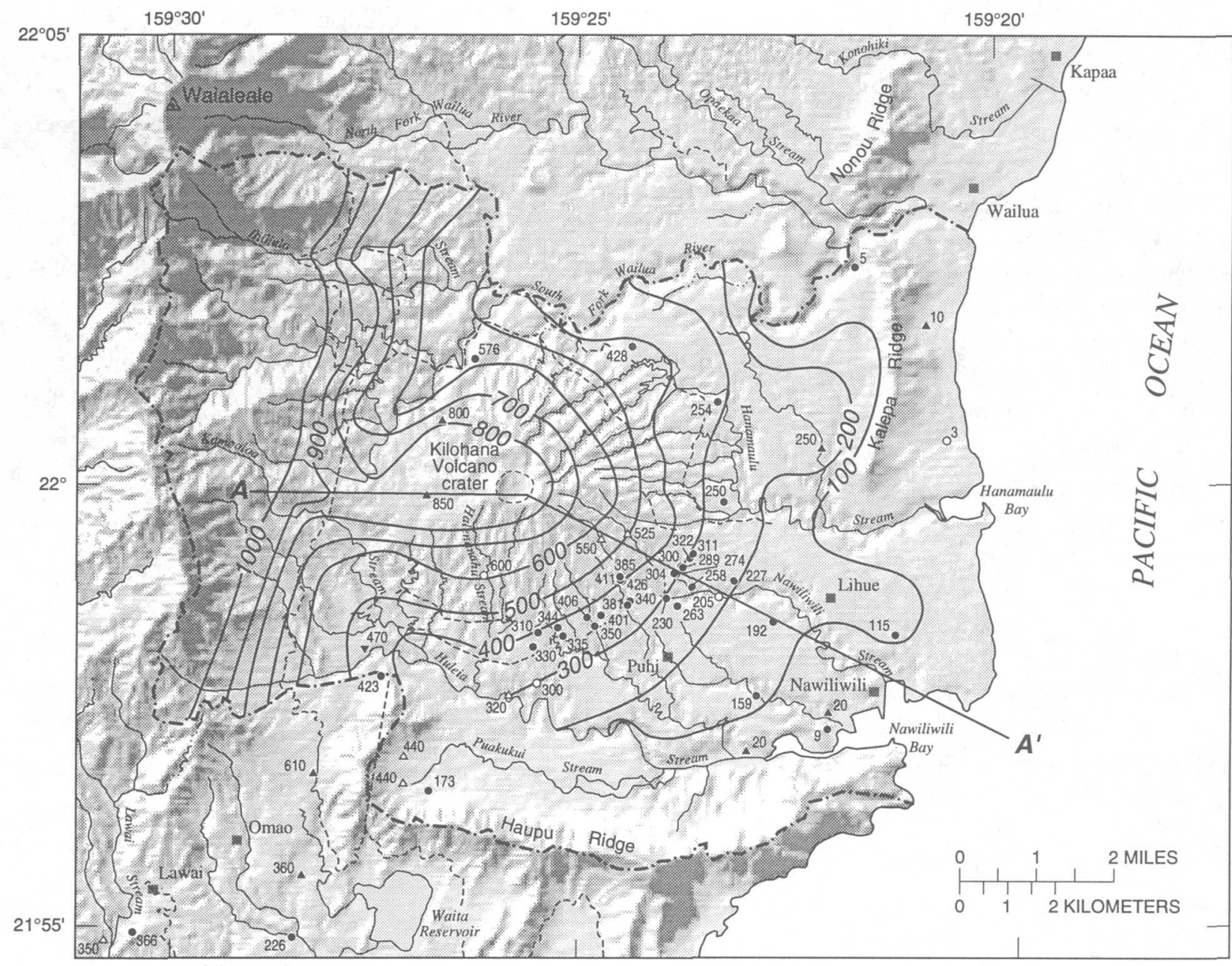

Base modified from U.S. Geological Survey digital data $1: 24,000,1983$, Albers equal area projection, standard parallels $21^{\circ} 5^{\prime} 40^{\prime \prime}$ and $22^{\circ} 10^{\prime} 20^{\prime \prime}$, central meridian $159^{\circ} 32^{\prime} 30^{\prime \prime}$
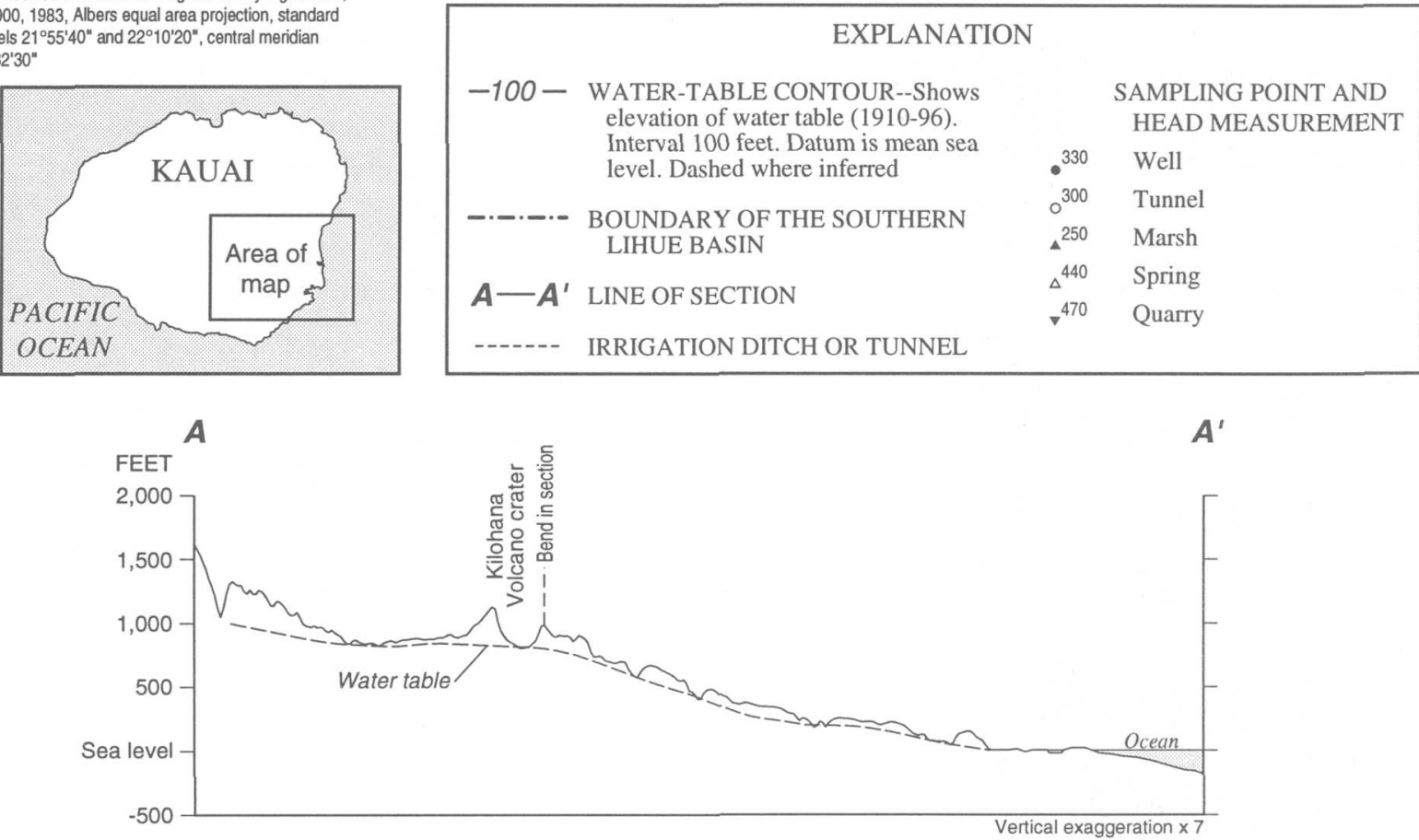

Figure 15. Generalized water-table map and profile for data from 1910 through 1996 for the southern Lihue Basin, Kauai, Hawaii. 
discharge. The point where the stream becomes perennial represents the intersection of the stream with the water table.

Additional data used to construct the water-table map include an unnamed quarry that appears to have been excavated into the water table about $0.5 \mathrm{mi}$ west of the confluence of Kamooloa and Huleia Streams, an unnamed water tunnel at an elevation of about $600 \mathrm{ft}$ on the western branch of Halenanahu Stream (fig. 15), and the observation that the crater floor of the Kilohana Volcano ( $820 \mathrm{ft}$ elevation) seeped water even after about 2 weeks with no antecedent rainfall.

The water-table map (fig. 15) shows that steep horizontal head gradients are characteristic throughout much of the southern Lihue Basin. The steep gradients are consistent with the low $K_{h}$ measured in most wells in the Koloa Volcanics. The map also shows how the water table is shaped by streams that incise into the ground-water body. Gradients are steepest where the aquifer is drained by streams, such as on the eastern slope of Kilohana Volcano. Gradients are flatter where few streams drain the ground water, such as in the western flank of the Kilohana Volcano and the flat area west of Kalepa Ridge where ground water has saturated the rock to the surface and marshes exist.

\section{Water levels in the Waimea Canyon Basalt.--}

Although there are no wells in the high central mountains of Kauai that form the western margin of the southern Lihue Basin, the large Alakai Swamp at an elevation of more than $4,000 \mathrm{ft}$ (fig. 1) indicates that the water table in the Waimea Canyon Basalt is thousands of feet above sea level in this area, probably because of the impounding effects of volcanic dikes within this formation. These heads are higher than any heads in the Koloa Volcanics in the Lihue Basin.

Well 5727-01 and the elevations of springs at the headwaters of Puakukui Stream indicate that water levels are about $400 \mathrm{ft}$ (fig. 15) in the western part of

Haupu Ridge. Water levels in the ridge decline toward the south and east. The water-level elevation was $173 \mathrm{ft}$ in well 5626-01, $147 \mathrm{ft}$ in well 5526-01, $35 \mathrm{ft}$ in well 5426-03, $31 \mathrm{ft}$ in well 5425-11, and $5 \mathrm{ft}$ in well 5523-01 (fig. 5). The steep horizontal ground-water gradient in the ridge is probably the result of the impounding effects of volcanic dikes. Well 0221-01 (figs. 5 and 15) indicates a water-level elevation of about $5 \mathrm{ft}$ in the Waimea Canyon Basalt of Kalepa Ridge.

\section{CONCEPTUAL MODEL OF GROUND- WATER OCCURRENCE AND MOVEMENT}

The data and analyses presented in this report indicate that ground water in the southern Lihue Basin originates as recharge from orographically distributed rainfall, flows eastward from the high mountains on the west, into the southern Lihue Basin, then to the north, east, and south where it discharges in streams or the ocean or flows to adjacent ground-water areas (fig. 16). The ground-water system in the southern Lihue Basin is characterized by a water table that is within a few tens of feet of the ground surface, steep horizontal head gradients, and flow through low-permeability rocks. A larger volume of ground water discharges to streams in the southern Lihue Basin than to the ocean.

The highest ground-water heads are found in the mountains on the western rim of the Lihue Basin where rainfall is highest and low-permeability intrusive dikes in the Waimea Canyon Basalt probably impound water to higher elevations in a system similar to that in windward Oahu (Takasaki and others, 1969; Takasaki and Mink, 1985). In windward Oahu, water from dikeintruded shield-building lavas analogous to those of the Waimea Canyon Basalt flows into overlying alluvium and rocks of rejuvenated volcanism analogous to those of the Koloa Volcanics, then discharges to streams. Heads in the Waimea Canyon Basalt west of the Lihue Basin are high as a result of the impounding effects of dikes and the Koloa Volcanics, in the same way heads in the Koolau Basalt of windward Oahu are high because water is impounded by dikes and overlying sediment and volcanic rocks. The Koloa Volcanics are more voluminous and provide greater storage and resistance to ground-water movement than analogous geologic units in windward Oahu, however.

The water-table map shows heads as high as $850 \mathrm{ft}$ above sea level in the Koloa Volcanics in the Lihue Basin. Macdonald and others (1960) attributed the high heads in the Koloa Volcanics to bodies of water held above unsaturated rock by low-permeability "perching members." Data from the present study, however, indicate that the high water levels are part of a completely saturated, not perched, ground-water system with steep vertical head gradients. Wells drilled hundreds of feet below sea level have water levels that are hundreds of feet above sea level indicating that the high water levels are part of a fully saturated system. The layering of low- 


\section{EXPLANATION}
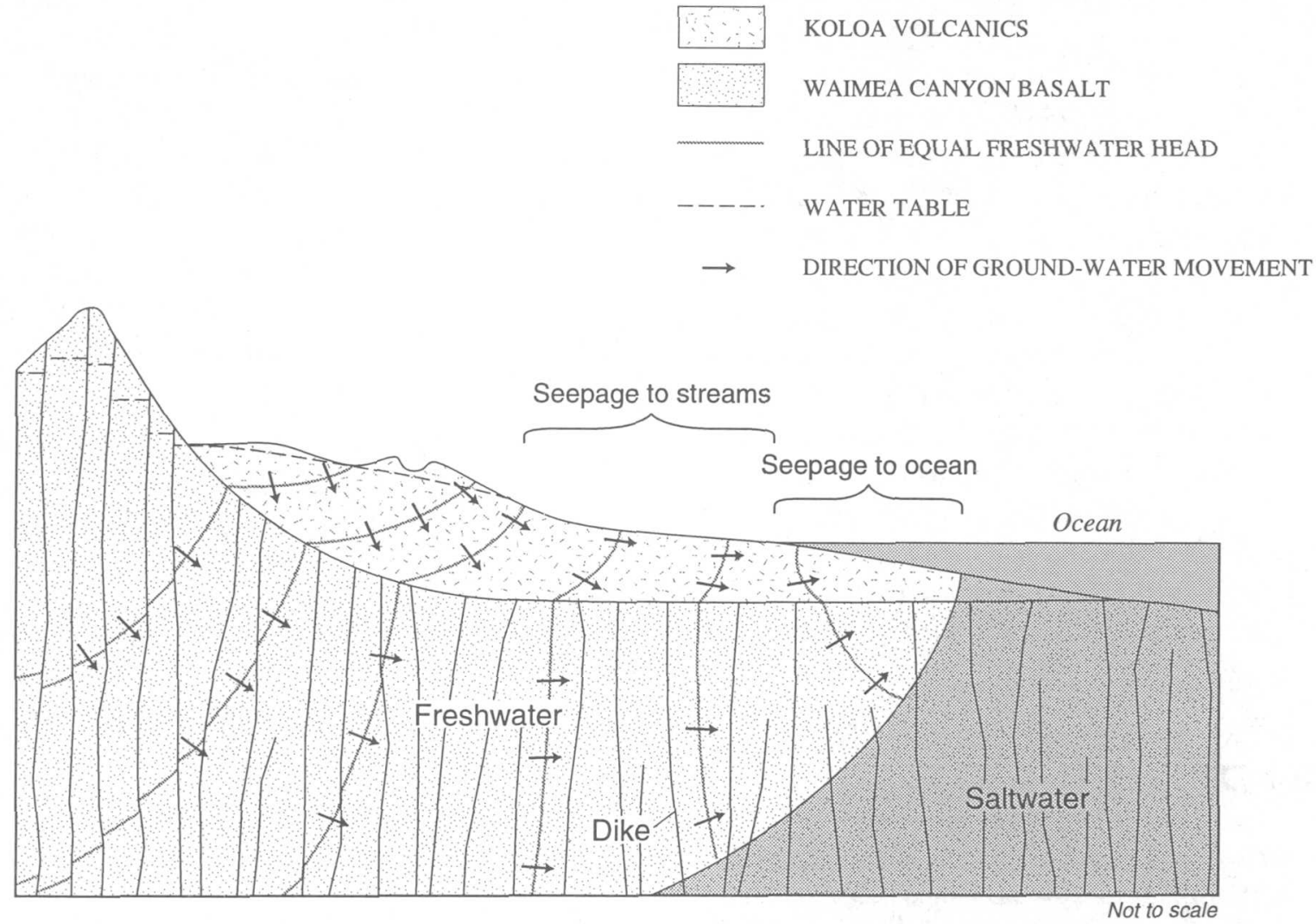

Figure 16. Diagrammatic representation of ground-water flow in the southern Lihue Basin, Kauai, Hawaii.

and high-permeability rocks which cause the stepwise water-level drops in the Kilohana, Puhi, and Haiku wells does not necessarily constitute a perched system. Perched water, by definition, is underlain by unsaturated rock. The water-level data and drilling records indicate that all layers are fully saturated. The high heads in the saturated ground-water system of the Koloa Volcanics result from low horizontal permeability combined with a high influx of water. The Koloa Volcanics receive water through the subsurface from the Waimea Canyon Basalt and through recharge from the surface. When this large influx of water encounters the high resistance to flow provided by the low permeability rock of the Koloa Volcanics, steep gradients result and high heads build in inland parts of the southern Lihue Basin.

Freshwater marshes at elevations of 800 and $850 \mathrm{ft}$ on the western flank of Kilohana Volcano and at an elevation of about $820 \mathrm{ft}$ in the crater indicate that ground water saturates the entire volcanic shield nearly to the surface. Streams incising the Koloa Volcanics drain the upper part of the aquifer and keep the water levels just below the ground surface in most places. The two major surface-water systems, the Wailua River and Huleia Stream, are incised deeply into the Koloa Volcanics and provide a means by which much of the ground water discharges. Between these larger streams, small streams such as Hanamaulu and Nawiliwili Streams incise the flank of Kilohana Volcano and drain the water table to a few tens of feet below the ground surface. Throughout most of their courses, the streams are youthful and have little or no streambed material overlying the bedrock of the stream channel, which probably allows greater exchange between ground water and the stream. The streams thus play an important part in shaping the water table in the Koloa Volcanics of the southern Lihue Basin. Water-budget calculations described earlier in this report indicate that at least 62 percent of recharge is 
eventually discharged to the streams and less than 34 percent discharges directly into the ocean.

Ground water that does not discharge to streams continues to flow southward and eastward through the Koloa Volcanics and Waimea Canyon Basalt of the Lihue Basin and Kalepa and Haupu Ridges, to eventually discharge at or beyond the coast. The nature of ground-water movement in the Waimea Canyon Basalt below the Koloa Volcanics in the southern Lihue Basin remains poorly known. It is likely that the underlying Waimea Canyon Basalt has numerous dikes and low bulk $K_{h}$ of less than $19 \mathrm{ft} / \mathrm{d}$ as do the ridges and mountains surrounding the southern Lihue Basin. The nature of ground-water flow south of Haupu Ridge was also not as well studied because it lies outside of the study area of this report. The $K_{h}$ of the Waimea Canyon Basalt probably increases to the south of the Lihue Basin as the frequency of dikes diminishes toward the flanks of the Kauai shield volcano.

\section{NUMERICAL MODEL OF GROUND- WATER MOVEMENT}

The conceptual model of ground-water occurrence and flow in the southern Lihue Basin is based on analysis of geology, permeability, recharge, natural groundwater discharge, and ground-water withdrawal data. To test the conceptual model, a numerical ground-water model of the southern Lihue Basin and adjacent areas was constructed. The numerical ground-water flow model was created using the finite-difference modeling program SHARP (Essaid, 1990). Because SHARP allows simulation of coupled freshwater and saltwater flow, the program is ideal for simulation of oceanicisland aquifers such as those in the southern Lihue Basin. The SHARP program is also capable of quasithree-dimensional simulations, which allows simulation of superposed aquifers with contrasting permeabilities, such as the Koloa Volcanics and the Waimea Canyon Basalt in the southern Lihue Basin. By using the SHARP program, ground-water flow is simulated using a porous-medium approach, although flow through lava-rock aquifers of the southern Lihue Basin may occur predominantly through high-permeability zones between lava flows or through fractures. The porous-medium approach is valid for the purposes of this study and the regional scale of the southern Lihue Basin model, but does not simulate local aquifer heter- ogeneities or preferential flow through thin, highpermeability layers.

The SHARP program treats the freshwater and saltwater as essentially immiscible domains separated by a sharp interface. Although the boundary between freshwater and saltwater in nature is actually a diffuse zone of mixing with a finite thickness, in aquifers (such as those in the southern Lihue Basin) where the freshwater thickness is much greater than the thickness of the zone of mixing, the zone can be approximated as a sharp interface. This simplifies the computations and input data requirements and shortens the computer computation time.

Horizontal flow of ground water is governed by user-defined horizontal aquifer properties and distribution of model-calculated freshwater and saltwater head. Vertical flow between layers is governed by userdefined vertical aquifer properties and differences between model-calculated head in adjacent layers. Discharge of ground water to streams and the ocean is governed by user-specified streambed and ocean-floor hydraulic properties and the difference between modelcalculated heads in the uppermost layer of the model and user-defined head in the streams and at the ocean bottom.

The study area was divided into cells which were assigned characteristics representing hydrogeologic properties, recharge, ground-water withdrawal, and streambed and ocean-floor hydraulic properties (table 4). These properties were assumed to be uniform within each cell. The model simulated freshwater and saltwater head distribution and flow on the basis of the assigned characteristics. To create a numerical ground-water model that accurately represents the southern Lihue Basin, hydraulic conductivities in the model were varied until simulated water levels matched observed water levels at selected sites. Model parameters which are assumed to be correct, such as ground-water withdrawal and recharge, were kept constant. Streambed and oceanfloor hydraulic properties, which, for reasons discussed below, are assumed to have little bearing on the hydrologic system, were also kept constant.

The model simulated steady-state (not time-dependent) conditions. Because of the nature of the equations involved in simulating coupled freshwater/saltwater flow, the SHARP program runs in the transient (time dependent) mode only. For steady-state simulations, SHARP runs a transient simulation until the head 
Table 4. Summary of selected characteristics and input data of the numerical model of the southern Lihue Basin, Kauai, Hawaii $\left[K_{h}\right.$, horizontal hydraulic conductivity; $K_{v}$ vertical hydraulic conductivity; datum is mean sea level]

\begin{tabular}{ll}
\hline Cell horizontal dimensions & 2,000 feet by 2,000 feet \\
Number of rows & 45 \\
Number of columns & 55 \\
Elevation of top of model & varies \\
Elevation of bottom of upper layer, top of lower layer & -500 feet \\
Elevation of bottom of model & $-6,000$ feet \\
Stream-bed and ocean-floor leakance & 1.99 day-1 \\
Ratio of $K_{v}$ to $K_{h}$ in the Koloa Volcanics & $1: 500$ \\
Ratio of $K_{v}$ to $K_{h}$ in flank lava flows of the Waimea Canyon Basalt & $1: 200$ \\
Ratio of $K_{v}$ to $K_{h}$ in dike-intruded lava flows of the Waimea Canyon Basalt & $1: 100$ \\
Length of time step & 10 days \\
Steady-state criterion & 0.001 feet \\
\hline
\end{tabular}

${ }^{a}$ Steady state considered to be achieved in the simulation when maximum head change between time steps is less than the steady-state criterion

change between successive time steps is smaller than a steady-state closure criterion (both the time step length and the steady-state criterion are defined by the program user), at which point the program considers steady state to have been achieved. The time step used in the southern Lihue Basin ground-water model was 10 days and the steady-state criterion was $0.001 \mathrm{ft}$.

\section{Model Structure and Input Data}

The southern Lihue Basin ground-water model simulates an area of $90,000 \mathrm{ft}(17.0 \mathrm{mi})$ by $110,000 \mathrm{ft}$ $(20.8 \mathrm{mi})$ in the southeast corner of Kauai and adjacent offshore areas (fig. 17). The area was divided into two layers, each layer was divided into 2,475 cells, each cell representing an area $2,000 \mathrm{ft}$ by $2,000 \mathrm{ft}$. The two-layer structure of the model allowed simulation of the contrast in hydrologic properties between the Koloa Volcanics and the underlying Waimea Canyon Basalt. The upper layer extends to an elevation of $-500 \mathrm{ft}$, which corresponds to the depth of the contact between the Koloa Volcanics and the underlying Waimea Canyon Basalt as shown in the geologic map of Macdonald and others (1960). The lower layer extends from $-500 \mathrm{ft}$ to $-6,000 \mathrm{ft}$ elevation.

Boundaries.--Models created using SHARP are bound on all sides except the top by no-flow boundaries. Because these no-flow boundaries on the periphery of the model are required, the modeled area must extend to natural no-flow boundaries such as impermeable geologic structures or ground-water divides or flow lines that are unaffected by changes in the study area. No impermeable structures exist within the southern
Lihue Basin to serve as no-flow boundaries for the model, but the model was extended far enough from the southern Lihue Basin that no-flow boundaries could be placed along ground-water divides and flow lines that will not substantially affect, or be affected by, changes in ground-water flow in the southern Lihue Basin.

The western no-flow boundary of the groundwater model was placed beyond the Hanapepe River and about $5.5 \mathrm{mi}$ from the margin of the southern Lihue Basin (fig. 17). The northern no-flow boundary was placed beyond the North Fork Wailua River. These boundaries roughly parallel the regional flow lines that would be expected as ground water flows from the high recharge areas at the center of the island to discharge areas at the coast. The no-flow boundary at the northwest corner of the model corresponds to a ground-water divide expected to exist beneath the Alakai Swamp (fig. 1). Ground-water withdrawal from the southern Lihue Basin is not likely to affect the location of these flow lines and ground-water divides because the propagation of the cones of depression will be halted by the large amount of water available through induced recharge or reduced ground-water discharge at rivers, streams, and coastlines within the model.

The southern and eastern no-flow boundaries of the ground-water model were placed in the ocean at a minimum of $2.5 \mathrm{mi}$ from the coast (fig. 17). This allowed sufficient space for the freshwater body in the model to expand seaward without impinging on the noflow boundary. The size of the freshwater body is a function of the hydraulic properties of the aquifer and the rate of recharge and discharge. 


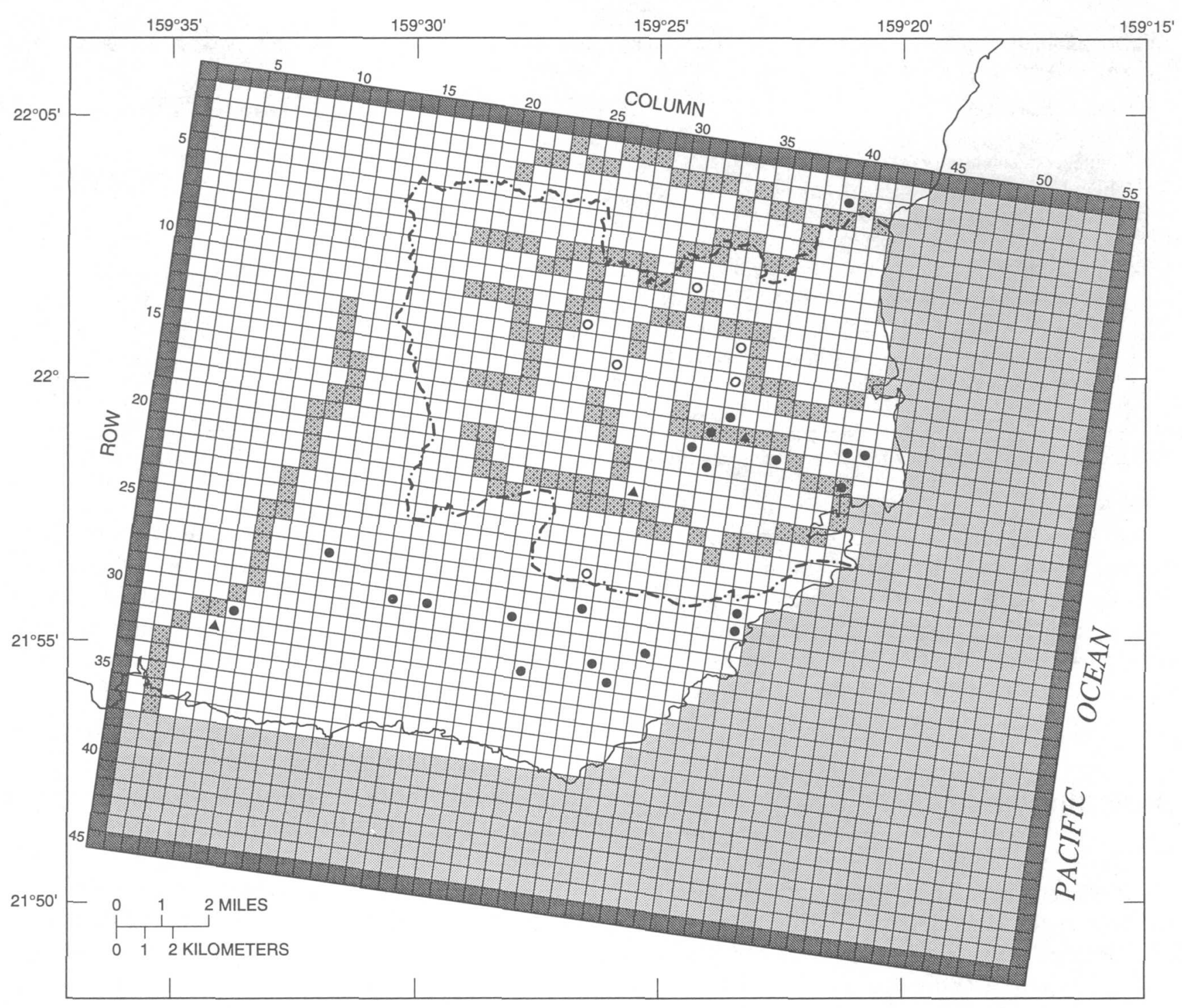

EXPLANATION

$\begin{array}{llll}\square & \text { UNCONFINED CELL (WATER TABLE) } & --\cdot & \text { BOUNDARY OF SOUTHERN } \\ & \text { NO-FLOW BOUNDARY CELL } & & \text { LIHUE BASIN } \\ \square & \text { OCEAN CELL } & \circ & \text { MONITORING POINT } \\ 7 & \text { STREAM CELL } & \bullet & \text { PUMPING WELL } \\ & & \triangle & \text { TUNNEL }\end{array}$
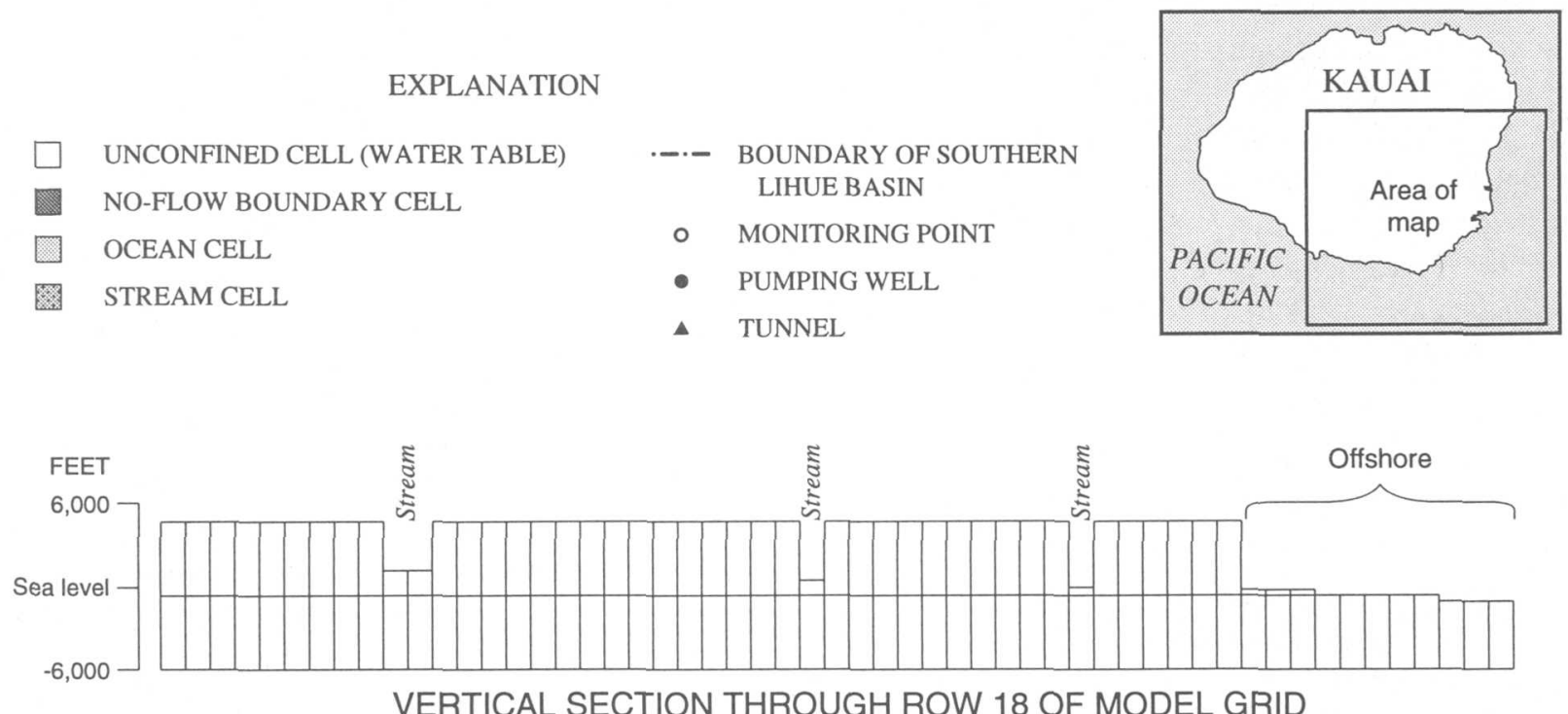

Figure 17. Discretization grid, boundaries, streams, pumping wells, and monitoring points used in the numerical ground-water model of the southern Lihue Basin, Kauai, Hawaii. 
The no-flow boundary at the base of the model was set at an elevation of $-6,000 \mathrm{ft}$, but precisely how deep in oceanic islands ground water actually flows is not well known. Geophysical evidence from Kilauea indicates that below $6,000 \mathrm{ft}$ from the ground surface porosity becomes nearly zero as a result of secondary mineralization (Kauahikaua, 1993). Kauai is much older and has probably undergone more diagenesis and subsidence than Kilauea. Still, placement of the no-flow boundary at $-6,000 \mathrm{ft}$ is at least consistent with the meager data available.

Hydrogeologic units.--The cells of the active part of the ground-water model were placed into one of three hydrogeologic categories: (1) the flank lava flows of the Waimea Canyon Basalt, (2) the Koloa Volcanics, and (3) the dike-intruded lava flows of the Waimea Canyon Basalt (fig. 18). These categories are defined on the basis of regional hydrologic properties. On the basis of aquifer tests, the Koloa Volcanics were expected to have the lowest permeabilities in the active part of the ground-water model. The flank lava flows of the Waimea Canyon Basalt were expected to have the highest permeabilities in the modeled area on the basis of knowledge of other flank lava flows in the Hawaiian islands. The dike-intruded lava flows of the Waimea Canyon Basalt were expected to have a bulk $K_{h}$ intermediate between the high-permeability flank lavas and the low-permeability Koloa Volcanics, on the basis of results from the aquifer test at well 5626-01. Dikeintruded parts of the Waimea Canyon Basalt were expected to have a lower ratio of $K_{h}$ to $K_{v}$ than dike-free parts of the formation because the vertically oriented sheet-like dikes probably reduce horizontal permeability more than vertical permeability. Regional hydraulic conductivities were obtained by varying $K_{h}$ and $K_{v}$ in the model until simulated heads at selected monitoring points matched observed heads.

Most of the model cells representing the ridges surrounding the Lihue Basin, and the cells in the lower layer beneath the basin and its surrounding ridges, were modeled as dike-intruded Waimea Canyon Basalt (fig. 18). The geologic map of Macdonald and others (1960) shows many dikes in the ridges. Dikes are probably also present beneath the Lihue Basin, particularly if the basin is the site of an old caldera as some investigators hypothesize.

The cells in the upper layer of the model within the Lihue Basin were modeled as Koloa Volcanics (includ- ing volcanic rock and sediments), which is consistent with the geologic map of Macdonald and others (1960). The Koloa Volcanics in the model extends the entire thickness of the upper layer (to $-500 \mathrm{ft}$ elevation), which is consistent with the drilling logs of monitor wells in the basin (Gingerich and Izuka, 1997a; Izuka and Gingerich, 1997a, 1997b, 1997c, 1997d). The multi-layering in parts of the Koloa Volcanics, indicated by stepwise declines in water levels during drilling in some wells, was too complex to model. Also, the local highpermeability area of the Koloa Volcanics in the Kilohana and Puhi well fields was too small to warrant differentiation from the rest of the Koloa Volcanics in the ground-water model for the purposes of this report. All of the Koloa Volcanics were thus modeled as a single layer with a uniform $K_{h}$ and $K_{v}$.

The remaining active cells were modeled as flank lava flows of the Waimea Canyon Basalt, including the area south and southwest of the Lihue Basin where outcrops of Koloa Volcanics are thin (Macdonald and others, 1960) and ground water probably flows predominantly through Waimea Canyon Basalt (fig. 18). All of the area modeled as flank flows of the Waimea Canyon Basalt lie outside the southern Lihue Basin and were not studied or modeled in as much detail as the area within the basin. The areas were included only as a gross approximation of the hydrologic properties between the study area and the required no-flow boundaries at the periphery of the model.

Recharge.--Recharge was distributed over the modeled area according to the average annual recharge of Shade (1995a) (fig. 19). The total recharge over the active cells of the modeled area is $296 \mathrm{ft}^{3} / \mathrm{s}$ or about 191 $\mathrm{Mgal} / \mathrm{d}$. Recharge through active onshore unconfined cells in the upper layer was entered in the recharge array of the model input data file. Recharge for stream cells was put into the model using injection wells in the input data file because streams were simulated as confined cells which cannot receive recharge in the SHARP program.

Streambed and ocean-floor leakance.--Unlike recharge and ground-water withdrawal, values of discharge to streams and the ocean are not entered directly in the model but are a function of user-defined streambed and ocean-floor leakance. Discharge to streams in the ground-water model was simulated with confinedaquifer cells in the upper layer (fig. 17). Ground water discharged from the model through these confined- 


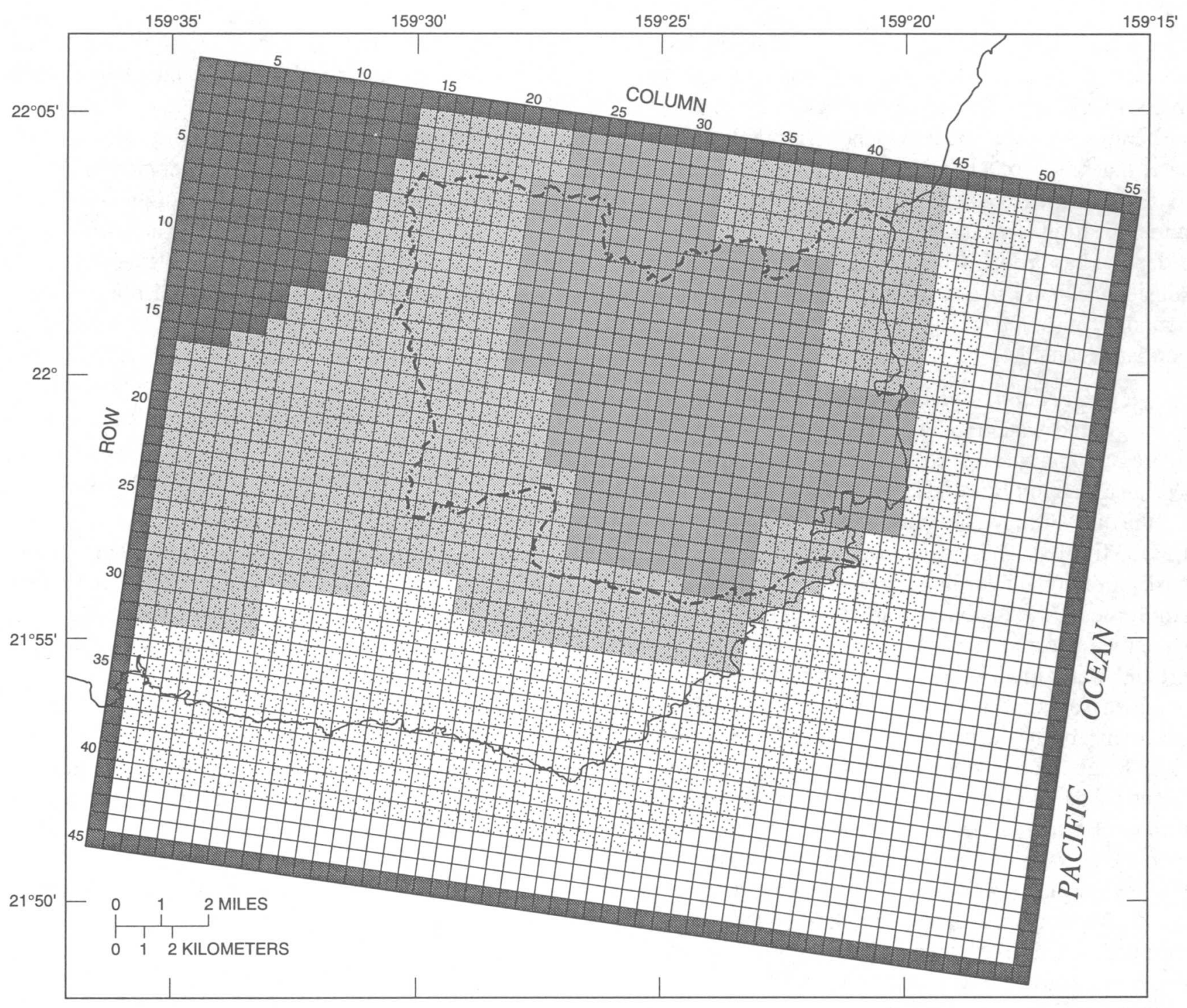

\section{UPPER LAYER}

EXPLANATION

BOUNDARY OF SOUTHERN
LIHUE BASIN
KOLOA VOLCANICS
$\begin{aligned} & \text { DIKE-INTRUDED WAIMEA } \\ & \text { CANYON BASALT }\end{aligned}$
$\begin{aligned} & \text { FLANK LAVA FLOWS OF THE } \\ & \text { WAIMEA CANYON BASALT }\end{aligned}$
NO-FLOW BOUNDARY CELL
$\quad$ OCEAN CELL

Figure 18. Distribution of geology used in the numerical ground-water model of the southern Lihue Basin, Kauai, Hawaii. 


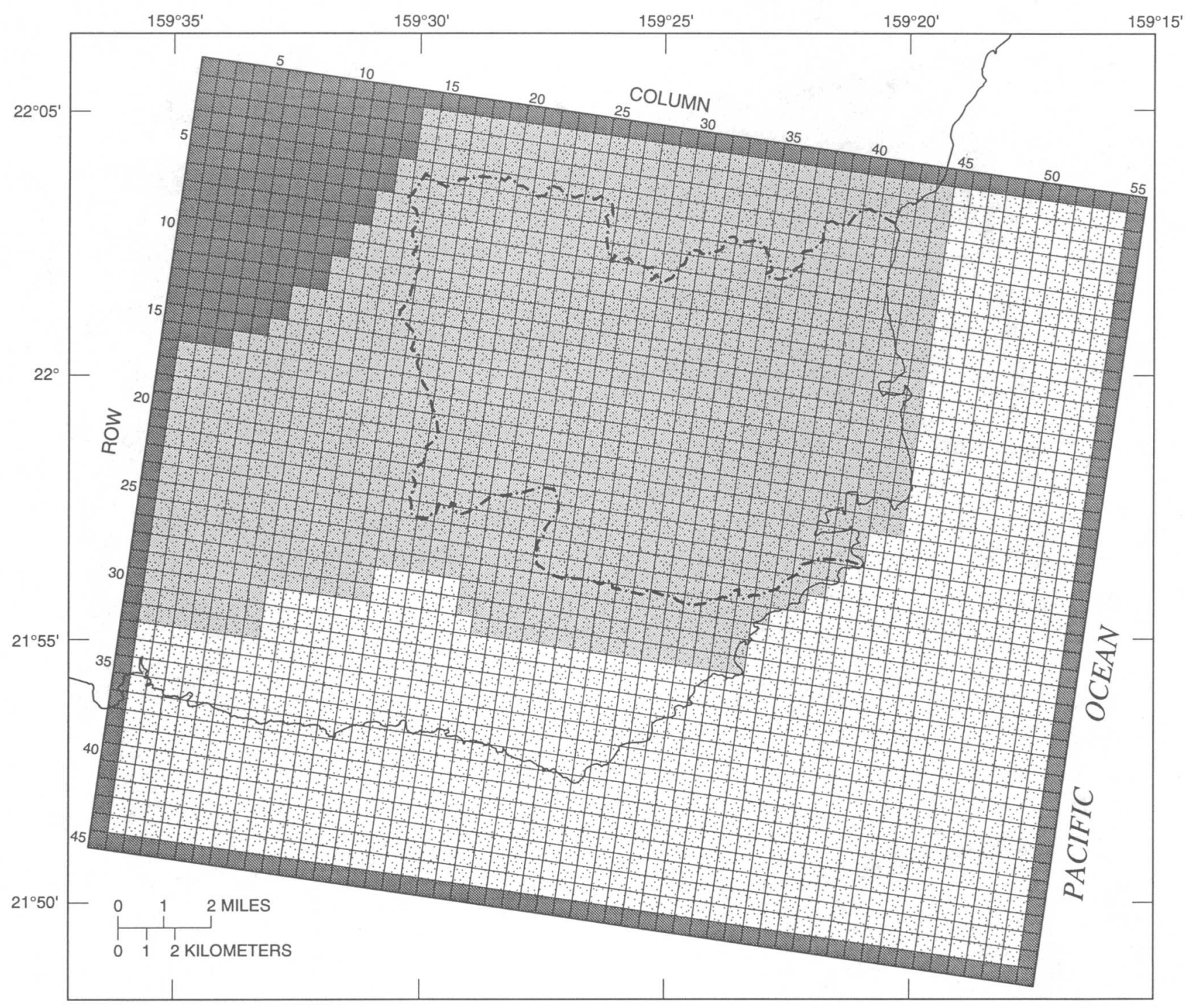

\section{LOWER LAYER}

\section{EXPLANATION}

BOUNDARY OF SOUTHERN
LIHUE BASIN
DIKE-INTRUDED WAIMEA
CANYON BASALT
FLANK LAVA FLOWS OF THE
WAIMEA CANYON BASALT
NO-FLOW BOUNDARY CELL

Figure 18. Distribution of geology used in the numerical ground-water model of the southern Lihue Basin, Kauai, Hawaii--Continued. 

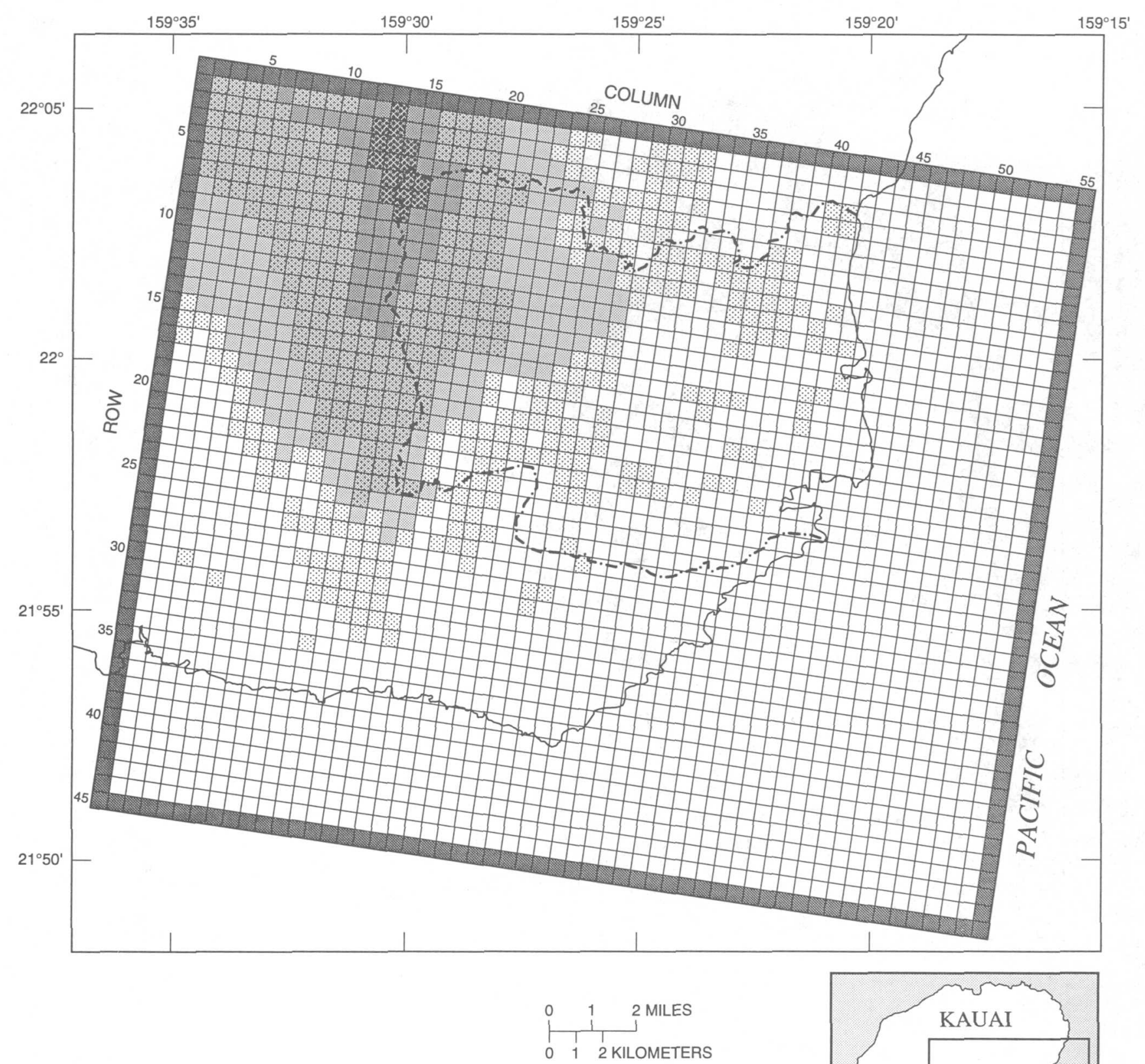

EXPLANATION

BOUNDARY OF SOUTHERN LIHUE BASIN
AVERAGE ANNUAL GROUND-WATER
RECHARGE, IN INCHES
Less than or equal to 10
Greater than 10 and less than or equal to 25
Greater than 25 and less than or equal to 50
Greater than 50 and less than or equal to 100
Greater than 100 and less than or equal to 150
NO-FLOW BOUNDARY CELL 150

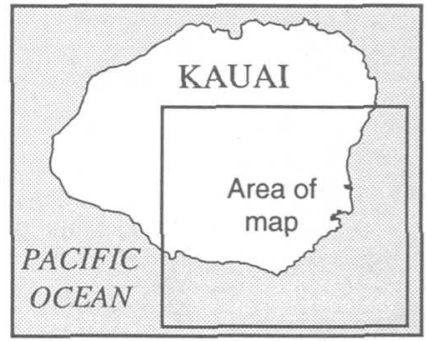

Figure 19. Distribution of recharge in the numerical ground-water model of the southern Lihue Basin, Kauai, Hawaii. 
aquifer cells when head in the cell exceeded the elevation specified for the top of the cell (which corresponds to the head in the stream channel). The constant head above the confined-aquifer cells was set equal to streambed elevations determined from topographic maps (U.S. Geological Survey, 1983a, 1983b, 1983c, 1983d, 1983e, 1983f).

The rate of discharge through the top of the confined-aquifer cells was a function of the user-specified streambed leakance. Leakance, $l$, is equal to $K_{v} / b$ where, for streambed leakance, $b$ is the saturated thickness of the aquifer between the midpoint and top of the stream cell and $K_{v}$ is the effective vertical hydraulic conductivity of the aquifer and streambed. This formulation assumes that all of the leakance happens vertically through a streambed that is as wide as the stream cell. In reality, however, streams on Kauai are much narrower than the 2,000-ft-wide cells of the model and are deeply incised, so that water discharges both horizontally and vertically to the stream channels. Most of the streams are youthful, have steep gradients and thin, coarse beds that have higher $K_{h}$ and $K_{v}$ than the underlying aquifer. Heads in the underlying aquifer are therefore primarily controlled by the hydraulic conductivities of the aquifer and are little affected by $K_{\nu}$ of the streambed. To simulate this condition, all stream cells were given a single high leakance value so that ground water could freely discharge to the stream as governed by $K_{h}$ of the aquifer and heads would not build artificially in response to the leakance.

Discharge to the ocean was simulated with confined-aquifer cells offshore. Discharge of ground water across the top of offshore cells depends on the userspecified ocean-floor leakance and the difference between the model-calculated heads in the cells and the head in the ocean above the cell. Because the water overlying the offshore cells is seawater, the head overlying the offshore cells was adjusted to account for the greater density of seawater. The equivalent freshwater head, relative to sea level, over offshore cells, $h_{f}$, was set equal to $1 / 40$ times the bathymetry. As with the streambed leakance, ocean-floor leakance was set at a high value (equal to the streambed leakance) so that it would not cause heads to build artificially in the aquifer. The model streambed and ocean-floor leakance was set at 1.99 day $^{-1}$ at all stream and offshore cells.
Leakance between upper and lower layers of the model.--Flow between upper and lower layers of the model is a function of the difference in head between the upper and lower layers and the value of leakance $(l)$ between layers. As with streambed leakance, $l$ is equal to $K_{v} / b$, but for flow between an upper-layer cell and the lower-layer cell directly beneath it, $b$ and $K_{v}$ are the distance and vertical hydraulic conductivity between midpoints of the saturated parts of each cell. Because the saturated thickness of each cell changes with the water-table elevation and depth to the interface between saltwater and freshwater as the SHARP program iterates to a solution, so too should the values of $b$ and $l$. The original version of SHARP does not recalculate $b$ and $l$ as freshwater thickness changes during iteration (Essaid, 1990). A modified version of the SHARP program which automatically recalculates leakance as thickness changes, was used to create the southern Lihue Basin model (appendix).

Because the lava flows that make up the Koloa Volcanics and Waimea Canyon Basalt are essentially horizontal structures, the value of $K_{v}$ is probably a fraction of $K_{h}$. In the southern Lihue Basin ground-water model, $K_{v}$ for each of the hydrogeologic units was computed as a proportion of the value of $K_{h}$. The value of $K_{v}$ has not been measured for Hawaiian lava flows but estimates have ranged from $1 / 3$ to $1 / 200$ of the value of $K_{h}$ (Hunt, 1996). For the flank lava flows of the Waimea Canyon Basalt, $K_{v}$ was assumed to be $1 / 200$ of $K_{h}$, which is similar to the ratio of $K_{v}$ to $K_{h}$ used by Souza and Voss (1987) for flank lava flows on Oahu. The ratio of $K_{v}$ to $K_{h}$ for the Koloa Volcanics is probably lower because the lava flows are thicker and intercalated with sediments. In the ground-water model, the $K_{v}$ of the Koloa Volcanics was assumed to be $1 / 500$ of $K_{h}$. The ratio of $K_{\nu}$ to $K_{h}$ for the dike-intruded part of the Waimea Canyon Basalt is likely to be higher than in the flank flows because dikes probably reduce $K_{h}$ more than $K_{v}$. In the ground-water model, $K_{v}$ of the dikeintruded part of the Waimea Canyon Basalt was assumed to be $1 / 100$ of $K_{h}$.

\section{Ground-water withdrawal.--Withdrawal of} ground water by wells was simulated by pumping cells in the ground-water model. Water was withdrawn from the pumping cells at a specified constant rate that corresponded with the withdrawal rates in table 2 , except that withdrawals from water tunnels are excluded (fig. 17, 
Table 5. Withdrawal rates in simulated pumping wells used in the numerical ground-water model of the southern Lihue Basin, Kauai, Hawaii

\begin{tabular}{|c|c|c|c|c|c|}
\hline \multicolumn{3}{|c|}{ Cell location } & \multirow{2}{*}{$\begin{array}{c}\text { Withdrawal } \\
\text { (million gallons per day) }\end{array}$} & \multirow{2}{*}{ State well number } & \multirow{2}{*}{ Well name } \\
\hline Row & Column & Layer & & & \\
\hline 3 & 39 & 2 & 0.24 & $0321-01$ & Nonou 9-1C \\
\hline 16 & 34 & 2 & 0.19 & $5923-05$ & Kilohana G \\
\hline 17 & 33 & 2 & 1.20 & $5923-01, \cdot 02,03,04,07$ & Kilohana A, B, C, F, I \\
\hline 17 & 41 & 2 & 0.21 & $5821-04,5821-03$ & Westin 1,2 \\
\hline 17 & 42 & 2 & 0.11 & $5820-01$ & Westin 3 \\
\hline 18 & 32 & 2 & 0.03 & $5824-03$ & Puhi 2 \\
\hline 18 & 37 & 2 & 0.10 & $5822-01,02$ & Sugar Mill, Grammar School \\
\hline 19 & 41 & 2 & 0.09 & $5821-06$ & Westin 5 \\
\hline 19 & 33 & 2 & 0.07 & $5824-01$ & Puhi 1 \\
\hline 27 & 12 & 1 & 0.45 & $5631-02,5631-02$ & Kalaheo A, B \\
\hline 27 & 36 & 2 & 0.01 & $5523-01$ & Kipu Kai \\
\hline 28 & 27 & 2 & 0.66 & $5526-01$ & $\mathrm{~K}-32$ \\
\hline 28 & 36 & 2 & 0.16 & $5523-02$ & Kipu Kai \\
\hline 29 & 16 & 2 & 1.29 & $5530-02,03,04$ & Lawai Cannery, Lawai 1, 2 \\
\hline 29 & 18 & 2 & 4.04 & $5529-01,03$ & Huinawai Res., Lawai A \\
\hline 29 & 23 & 2 & 1.10 & $5527-01$ & Kahaono \\
\hline 30 & 31 & 2 & 0.96 & $5425-11$ & Mahaulepu 11 \\
\hline 31 & 7 & 1 & 0.20 & $5533-01,02$ & Hanapepe A, B \\
\hline 31 & 28 & 1 & 2.44 & $5426-03$ & Koloa \\
\hline 32 & 24 & 1 & 0.70 & $5427-01,02$ & Koloa A, B \\
\hline 32 & 29 & 1 & 1.25 & $5426-05$ & Koloa C, D \\
\hline
\end{tabular}

table 5). The water tunnels were simulated as leaky confined-aquifer cells rather than pumping cells because they capture water that would have otherwise discharged at nearby streams and they are located so close to streams (much less than the 2,000-ft width of the cells in the model) that hydraulic connection to surface water cannot be precluded. Reported withdrawal at Hanapepe Tunnel Pump 3 (well 5534-01) is known to come partly from surface-water sources and the proportion of ground water to surface water captured by the well is unknown. The high withdrawals from the Kokolau (well 5725-01) and Garlinghouse Tunnels (well 582301) may also reflect local high-permeability connections to nearby streams that are too small to be simulated at the regional scale of the ground-water model. The head overlying the confined cell representing the Kokolau and Garlinghouse Tunnels was set at the elevation of the bottom of the tunnels. The head overlying the cell representing the Hanapepe Tunnel Pump 3 (the bottom of which is $50 \mathrm{ft}$ below sea level) was level set at sea level because well records indicate that water levels in the tunnel during pumping are near sea level. Leakance for the tunnels was the same as that used for streambeds and the ocean floor.

\section{Hydraulic Conductivities, Water Levels, Ground-Water Discharge, and Interface Depth of the Best-Fit Numerical Model}

Values of $K_{h}$ for the numerical model were varied within the active cells of the model until water levels at specified monitoring points matched known water levels (to keep the ratio of $K_{v}$ to $K_{h}$ constant, $K_{v}$ was varied proportionally with $K_{h}$ ). Recharge, ground-water withdrawal, and streambed and ocean-floor leakance were kept constant.

The specified monitoring points included four wells $(5923-08,0023-01,0124-01$, and 0126-01) in the Koloa Volcanics, one well in the dike-intruded Waimea Canyon Basalt of Haupu Ridge (well 5626-01), and the elevation of ground-water discharge observed in the crater of Kilohana Volcano (figs. 5 and 17). All of the wells used as monitoring points were drilled in 1995-96 and the first water level measured in each well during drilling represents the water table at that time. The elevation of the crater floor of Kilohana Volcano (U.S. Geological Survey, 1983e) also was chosen as a monitoring point because field data and the conceptual model indicate that the water table intersects the crater 
Table 6. Hydraulic conductivities used in the best-fit numerical ground-water model of the southern Lihue Basin, Kauai, Hawaii

\begin{tabular}{lcc}
\hline \multicolumn{1}{c}{$\quad$ Hydrogeologic unit } & $\begin{array}{c}\text { Horizontal } \\
\text { hydraulic conductivity } \\
\text { (feet per day) }\end{array}$ & $\begin{array}{c}\text { Vertical } \\
\text { hydraulic conductivity } \\
\text { (feet per day) }\end{array}$ \\
\hline Koloa Volcanics & 0.275 & 0.00055 \\
Dike-intruded lava flows of the Waimea Canyon Basalt & 1.11 & 0.0111 \\
Flank lava flows of the Waimea Canyon Basalt & 200 & 1 \\
\hline
\end{tabular}

floor and is relatively flat there compared with the steeply sloping water table on the flanks and stream channels of the Kilohana Volcano. The water level indicated by the crater floor is therefore less prone to difficulties associated with steep ground-water gradients elsewhere in the southern Lihue Basin.

The dike-confined Waimea Canyon Basalt in the best-fit model has a $K_{h}$ of $1.11 \mathrm{ft} / \mathrm{d}$ (table 6 ), which is lower than the $K_{h}(19 \mathrm{ft} / \mathrm{d})$ estimated from the aquifer test of well 5626-01. The lower model-simulated $K_{h}$ is expected because it reflects the average bulk regional $K_{h}$, including many dikes. The estimate of $K_{h}$ from the aquifer test reflects only the local area, which may have no dikes, reached by the cone of depression during the short period of the aquifer test. The flank flows of the Waimea Canyon Basalt in the best-fit model have a $K_{h}$ of $200 \mathrm{ft} / \mathrm{d}$.

With these values of hydraulic conductivity, the pattern of simulated head distribution in the upper layer (fig. 20) is consistent with the water-table map constructed from field data (fig. 15). The model reproduces major features of the water-table map, including the high ground-water levels that are shaped by groundwater discharge to streams. The model-simulated water level in the upper layer at well 0124-01 is within $3 \mathrm{ft}$ of the observed water level (table 7). The model-simulated water level at the crater of Kilohana Volcano is about 30 $\mathrm{ft}$ lower than the observed water level (table 7), but the observed water-level elevation has an uncertainty of about $40 \mathrm{ft}$ because it was estimated from elevation contours on a 1:24,000-scale USGS topographic map (U.S. Geological Survey, 1983e). Simulated water levels at wells 5923-08 and 0023-01 were about 50 to $60 \mathrm{ft}$ higher than observed, and at well 0126-01 was $110 \mathrm{ft}$ higher than observed, but these differences are artifacts of the model discretization of a steep water-table gradient. Whereas the observed data represent a point on the steep gradient, the water level in the cell of the model represents an average of the water levels within the $2,000-\mathrm{ft}$ by $2,000-\mathrm{ft}$ square model cell. Also, water levels in wells represent a vertically averaged head over the distance the well penetrates, whereas the head in a cell is averaged over the entire thickness of the cell. Considering that water-level elevations range widely throughout the southern Lihue Basin, and water levels in the steep gradients near the monitoring points can vary by $100 \mathrm{ft}$ over a horizontal distance of $2,000 \mathrm{ft}$, the simulated water levels in the best-fit model closely approximate the observed water levels. The difference between observed and simulated water level at well 5626-01 reflects the effect of withdrawals at nearby well 552601 . The observed water level at 5626-01 was measured when 5526-01 was not in operation, but may not have fully recovered from previous pumping. The modelsimulated water level for well 5626-01 is $10 \mathrm{ft}$ lower than observed when withdrawal at well 5526-01 is simulated and $11 \mathrm{ft}$ higher than observed when withdrawal at 5526-01 is not simulated (table 7). Model-simulated heads in the lower layer beneath the southern Lihue Basin ranged from about 50 to $350 \mathrm{ft}$ above the sealevel datum (fig. 20). There are no field data with which to compare these heads.

Simulated ground-water discharges at most major streams and rivers (table 8) agree closely with groundwater discharges estimated from base-flow analyses (table 1). Simulated ground-water discharge at Huleia Stream is about 44 percent lower than ground-water discharge estimated from base-flow analyses, but simulated ground-water discharges at Hanamaulu Stream, South Fork Wailua River, and the Hanapepe River are within 5 percent of ground-water discharges estimated from base-flow analyses. Simulated ground-water discharge to streams in the model is greater than groundwater discharge to the ocean, which is consistent with the base-flow analyses and instantaneous stream discharge measurements.

Simulated ground-water discharges to all three water tunnels were lower than the reported withdrawals. Simulated ground-water discharge to the Hanapepe Tunnel Pump 3 (well 5534-01) near Hanapepe River was $0.26 \mathrm{Mgal} / \mathrm{d}$ which is only 2 percent of the reported pumpage (table 2). The discrepancy can be attributed to the inclusion of surface water in the reported withdrawal from this well. Indeed, Shade (1995b) consid- 


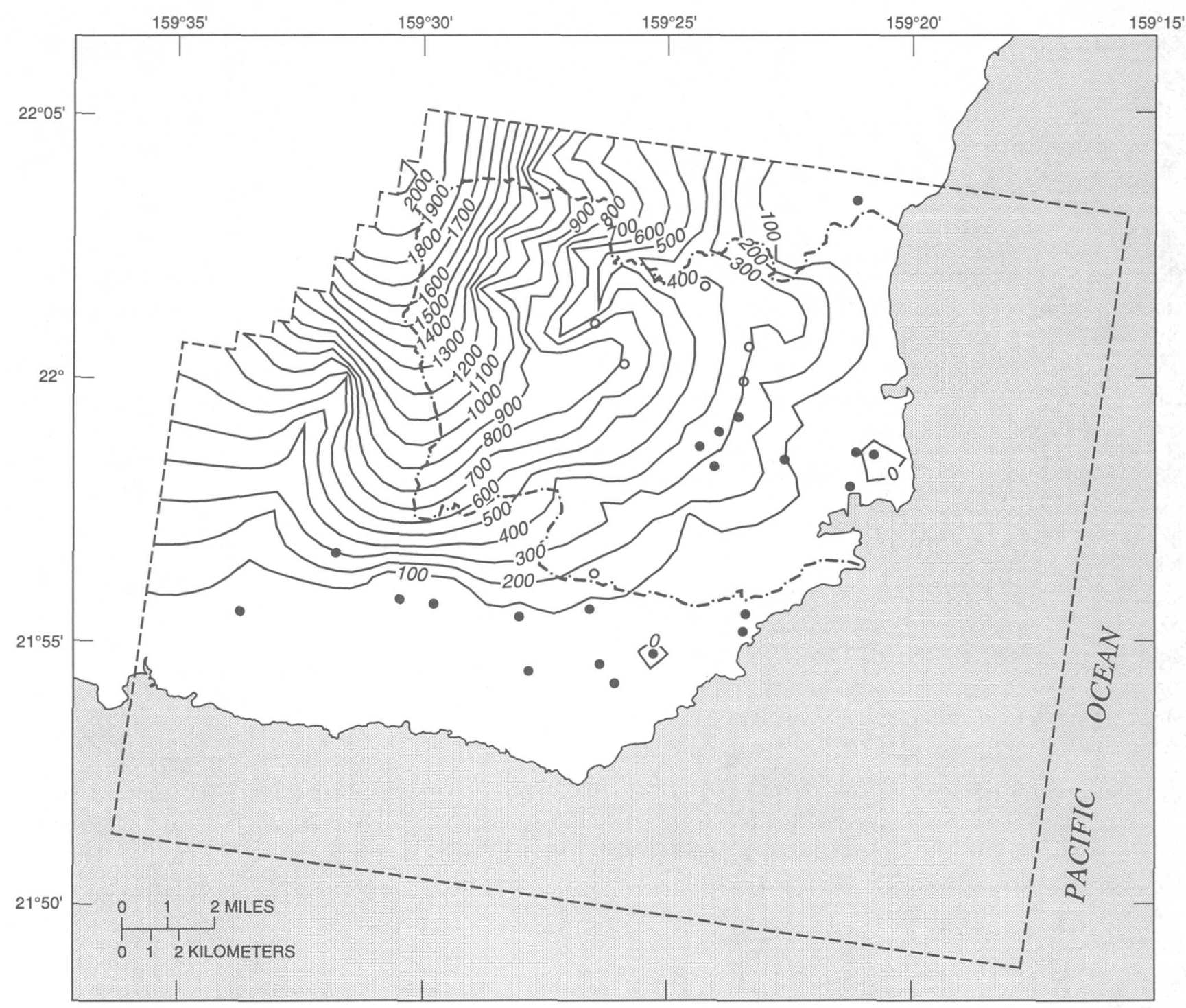

UPPER LAYER

EXPLANATION

$-100-$ LINE OF EQUAL MODEL-CALCULATED
GROUND-WATER HEAD-Interval
100 feet. Datum is mean sea level

- - - - NO-FLOW BOUNDARY

-.-.-_ BOUNDARY OF SOUTHERN LIHUE BASIN

- MONITORING POINT

- $\quad$ PUMPING WELL

Figure 20. Distribution of simulated head in the upper layer and lower layer of the numerical ground-water model of the southern Lihue Basin, Kauai, Hawaii. 


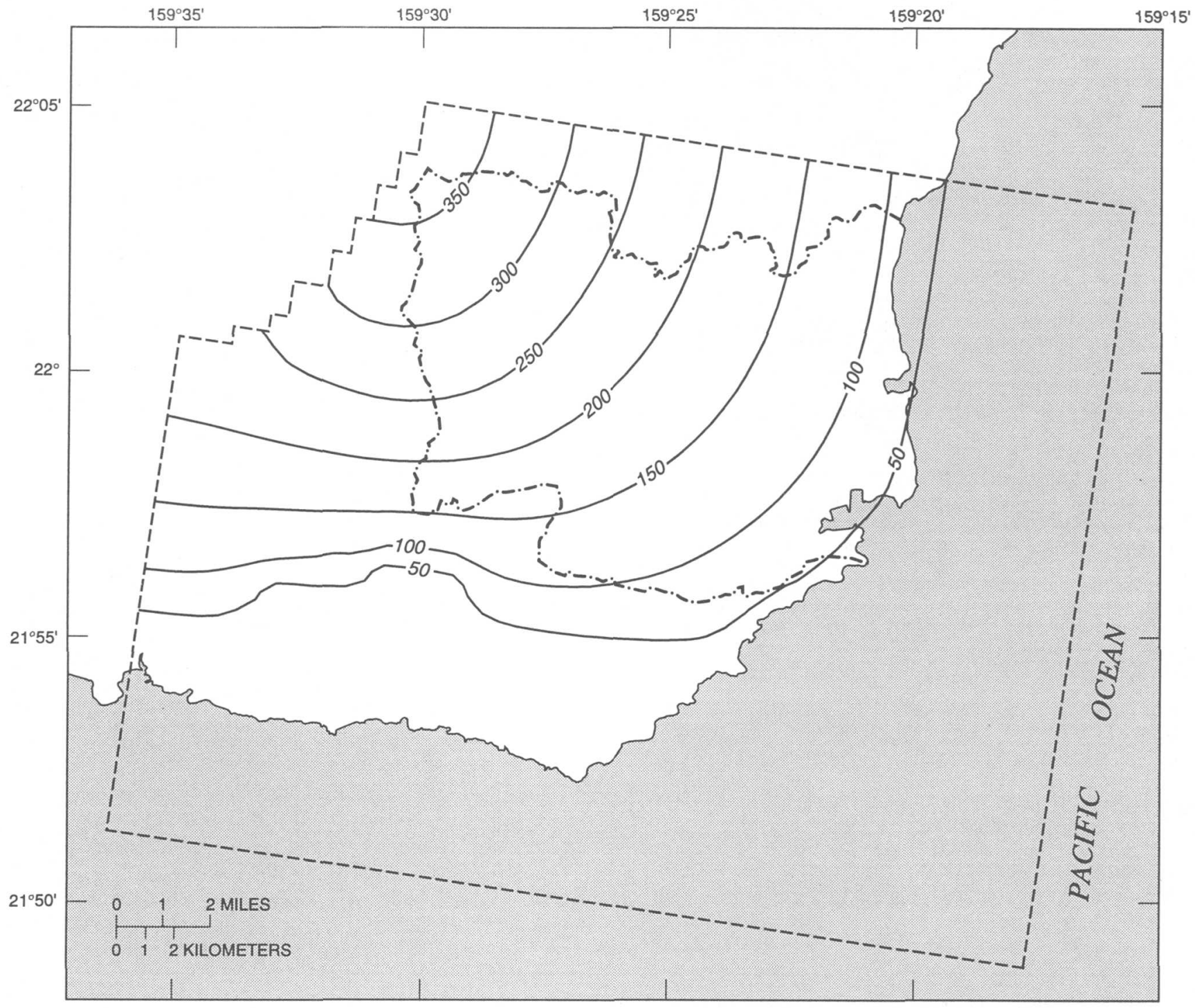

\section{LOWER LAYER}

\section{EXPLANATION}

-100- LINE OF EQUAL MODEL-CALCULATED

GROUND-WATER HEAD--Interval

50 feet. Datum is mean sea level

---- NO-FLOW BOUNDARY

-.-.- BOUNDARY OF SOUTHERN LIHUE BASIN

Figure 20. Distribution of simulated head in the upper layer and lower layer of the numerical ground-water model of the southern Lihue Basin, Kauai, Hawaii--Continued. 
Table 7. Observed and simulated water levels from the upper layer of the numerical ground-water model of the southern Lihue Basin, Kauai, Hawaii

[Water levels in feet above mean sea level; all changes indicated were made on the best-fit model while keeping all other parameters the same as in the best-fit model]

\begin{tabular}{|c|c|c|c|c|c|c|}
\hline \multirow[b]{2}{*}{ Water levels from } & \multicolumn{6}{|c|}{ Monitoring points (well number and name) } \\
\hline & $\begin{array}{c}5626-01 \\
\text { Puakukui } \\
\text { Springs }\end{array}$ & $\begin{array}{c}0126-01 \\
\text { Northwest } \\
\text { Kilohana }\end{array}$ & $\begin{array}{c}0124-01 \\
\text { Northeast } \\
\text { Kilohana }\end{array}$ & $\begin{array}{c}5923-08 \\
\text { Hanamaulu }\end{array}$ & $\begin{array}{c}\text { Kilohana } \\
\text { Volcano } \\
\text { crater }\end{array}$ & $\begin{array}{c}\text { 0023-01 } \\
\text { Pukaki } \\
\text { Reservoir }\end{array}$ \\
\hline Observed & 173 & 576 & 428 & 243 & $820^{\mathrm{a}}$ & 252 \\
\hline Best-fit model & 162 & 686 & 423 & 296 & 790 & 312 \\
\hline Pumpage at 5526-01 removed & 184 & 686 & 423 & 296 & 790 & 312 \\
\hline Streambed and ocean-floor leakance multiplied by 2 & 162 & 686 & 423 & 296 & 790 & 312 \\
\hline Streambed and ocean-floor leakance multiplied by 0.5 & 162 & 686 & 423 & 296 & 790 & 312 \\
\hline Streambed and ocean-floor leakance multiplied by 0.1 & 163 & 686 & 423 & 296 & 790 & 312 \\
\hline Streambed and ocean-floor leakance multiplied by 0.01 & 163 & 687 & 424 & 296 & 791 & 312 \\
\hline $\begin{array}{l}\text { Streambed and ocean-floor leakance multiplied by } \\
0.001\end{array}$ & 166 & 699 & 426 & 299 & 795 & 315 \\
\hline $\begin{array}{l}\text { Withdrawals from pumping cells stopped (leakage to } \\
\text { tunnels maintained) }\end{array}$ & 194 & 686 & 423 & 302 & 791 & 313 \\
\hline $\begin{array}{l}\text { Withdrawals from pumping cells and leakage to tunnels } \\
\text { stopped }\end{array}$ & 194 & 686 & 423 & 303 & 791 & 313 \\
\hline Vertical hydraulic conductivity multiplied by 2 & 162 & 681 & 422 & 291 & 781 & 310 \\
\hline Vertical hydraulic conductivity multiplied by 0.5 & 164 & 689 & 425 & 299 & 796 & 314 \\
\hline Recharge multiplied by 2 & 226 & 803 & 468 & 323 & 932 & 330 \\
\hline Recharge multiplied by 0.5 & 128 & 623 & 400 & 282 & 713 & 303 \\
\hline $\begin{array}{l}\text { Hydraulic conductivity of Koloa Volcanics multiplied } \\
\text { by } 2\end{array}$ & 175 & 624 & 401 & 287 & 717 & 305 \\
\hline $\begin{array}{l}\text { Hydraulic conductivity of Koloa Volcanics multiplied } \\
\text { by } 0.5\end{array}$ & 152 & 800 & 467 & 314 & 926 & 327 \\
\hline $\begin{array}{l}\text { Hydraulic conductivity of dike-intruded Waimea } \\
\text { Canyon Basalt multiplied by } 2\end{array}$ & 135 & 684 & 422 & 294 & 787 & 311 \\
\hline $\begin{array}{l}\text { Hydraulic conductivity of dike-intruded Waimea } \\
\text { Canyon Basalt multiplied by } 0.5\end{array}$ & 202 & 688 & 424 & 297 & 794 & 313 \\
\hline $\begin{array}{l}\text { Hydraulic conductivity of flank Waimea Canyon Basalt } \\
\text { multiplied by } 2\end{array}$ & 161 & 686 & 423 & 296 & 790 & 312 \\
\hline $\begin{array}{l}\text { Hydraulic conductivity of flank Waimea Canyon Basalt } \\
\text { multiplied by } 0.5\end{array}$ & 164 & 686 & 423 & 296 & 790 & 312 \\
\hline
\end{tabular}

a Estimated from topographic contours on the U.S. Geological Survey 1:24,000-scale Waialeale quadrangle map (1983)

Table 8. Simulated ground-water discharge to streams, rivers, and the ocean in the best-fit numerical ground-water model of the southern Lihue Basin, Kauai, Hawaii

[nd, not determined; $\mathrm{ft}^{3} / \mathrm{s}$, cubic feet per second]

\begin{tabular}{lcc}
\multicolumn{1}{c}{ Seepage to } & $\begin{array}{c}\text { Simulated } \\
\text { ground-water discharge } \\
\left(\mathrm{ft}^{3 / s}\right)\end{array}$ & $\begin{array}{c}\text { Estimated base-flow from analysis } \\
\text { of stream-gaging records } \\
\left(\mathbf{f}^{3} / \mathbf{s}\right)\end{array}$ \\
\hline North Fork, Wailua River & 33.0 & nd \\
South Fork, Wailua River & 86.1 & 88 and 115 \\
Hanamaulu Stream & 5.9 & 5 to 7 \\
Nawiliwili Stream & 1.8 & nd \\
Huleia Stream & 18.7 & 33.4 \\
Hanapepe River & 69.6 & 71.8 \\
Ocean & 52.8 & nd \\
\hline
\end{tabular}

${ }^{1}$ From table 1 
ered all of the $13.24 \mathrm{Mgal} / \mathrm{d}$ reportedly withdrawn from that well to have a surface water source. Simulated ground-water discharge to the Garlinghouse Tunnel (well 5823-01) near Nawiliwili Stream was $0.26 \mathrm{Mgal} / \mathrm{d}$ which is about 24 percent of the reported withdrawal, and simulated ground-water discharge to the Kokolau Tunnel (well 5725-01) near Huleia Stream was 0.19 $\mathrm{Mgal} / \mathrm{d}$ which is about 33 percent of the reported withdrawal. Because these wells are close to streams, the discrepancies between reported withdrawals and simulated ground-water discharges may result from local connections to surface water that cannot be simulated at the scale of the regional model. The hydraulic characteristics of the area near the tunnels can be varied until the simulated ground-water discharge matches the reported withdrawals more closely, but the validity of the outcome could not be tested because the proportion of ground water to surface water in the reported withdrawals is not known. Because the tunnel discharges represent only a small fraction of the total ground-water flow through the Lihue Basin, the discrepancies between simulated and reported tunnel withdrawals have little effect on the numerical model's function as a means for testing the regional conceptual model. The inaccuracy of the simulated tunnel withdrawals, however, limits the model's applicability in local studies near the tunnels, such as assessing the effects of nearby well pumpages on tunnel yields.

The simulated freshwater/saltwater interface intersects the lower boundary of the model at $-6,000 \mathrm{ft}$ elevation where the simulated freshwater lens impinges on the bottom of the model (fig. 21). The interface rises to the east and south, and intersects the top of the lower layer (-500 ft elevation) about 1 to $2 \mathrm{mi}$ off the coast. Along the eastern coast between the seaward end of Haupu Ridge and the Wailua River, the simulated interface in the upper layer rises steeply from $-500 \mathrm{ft}$ elevation to the top of the model. Along the south coast from Haupu Ridge to the Hanapepe River, the interface rises less steeply from $-500 \mathrm{ft}$ elevation about one half to one mile inland from the coast to the top of the model near the coastline. There are no field data with which to compare the simulated interface depths.

\section{Sensitivity of the Model to Parameter Variability}

The resulting distribution of hydraulic conductivities is based on the premise that the water levels and non-varied parameters are representative of the hydrologic system being modeled. Whereas water-level measurements have little uncertainty, stream and ocean leakance, ground-water withdrawal, ratio of $K_{v}$ to $K_{h}$, and recharge are less precisely known. Each of these parameters was varied in separate simulations to test how the model results may be affected by these uncertainties. Most of the test simulations reached steady state. Two test simulations (identified in table 7) were halted before achieving steady state because the they had failed to meet the steady-state criterion even after 32,000 time steps (starting from the best-fit heads). However, for the purposes of this sensitivity analysis, the heads at the monitoring points are considered representative of steady-state conditions because heads at the monitoring points changed very little for thousands of time steps before the end of the simulations.

To test whether the streambed and ocean-floor leakance in the best-fit model was high enough to be consistent with the conceptual model, leakance was varied from 2 to 0.001 times the value of leakance (set at 1.99 day $^{-1}$ ) of the best-fit model (table 7). Simulated heads were unaffected when leakances were higher than about 1 day $^{-1}$ (fig. 22). This indicates that the leakance value used for streambeds and the ocean floor is sufficiently high that the effect on the heads in the aquifer is insignificant, which is consistent with the conceptual model.

Sensitivity of the model to uncertainties in groundwater withdrawal was tested by comparing the best-fit model with (1) a simulation in which withdrawals from all pumping cells were stopped but leakage to water tunnels was maintained, and (2) a simulation in which withdrawals from all pumping cells and leakage to water tunnels were stopped (table 7). Except for wells 5923-08 and 5626-01, water levels at the monitoring points showed differences of $1 \mathrm{ft}$ or less between the best-fit model and the simulations without withdrawals. The water level in well 5923-08 in the best-fit model was 6 to $7 \mathrm{ft}$ lower than in the non-withdrawal simulations, which shows the effect of the nearby Kilohana and Puhi well fields and the Garlinghouse Tunnel (well 5823-01). The effect is small, however, relative to the steep ground-water gradients that cause hundreds of feet of water-level variation in southern Lihue Basin. The water level in well 5626-01 at the periphery of the southern Lihue Basin was $10 \mathrm{ft}$ lower in the best-fit model than in the non-withdrawal simulations, which shows the effect of well 5526-01 and other wells south 

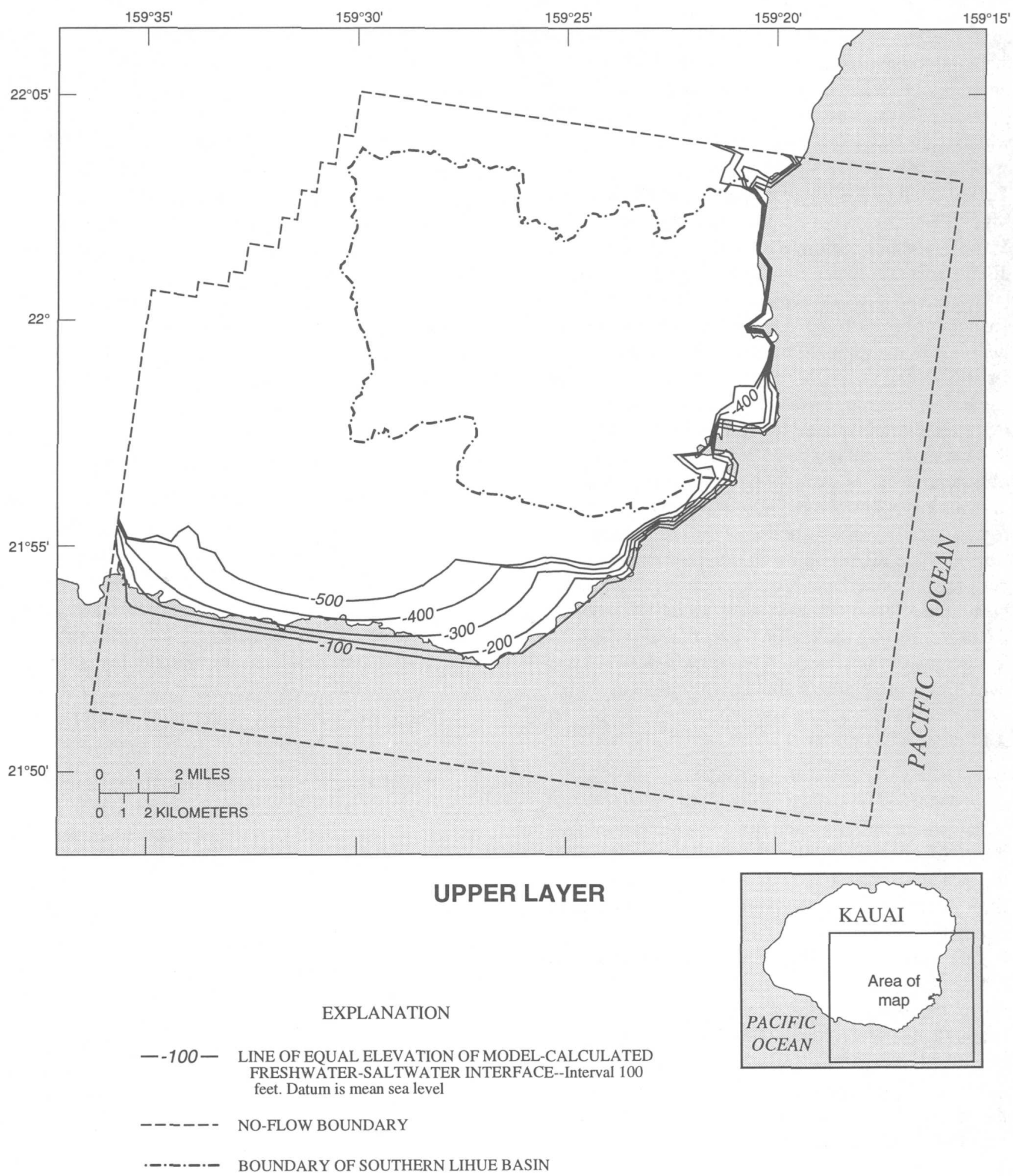

Figure 21. Simulated elevation of the freshwater/saltwater interface in the upper layer and lower layer of the numerical ground-water model of the southern Lihue Basin, Kauai, Hawaii. 


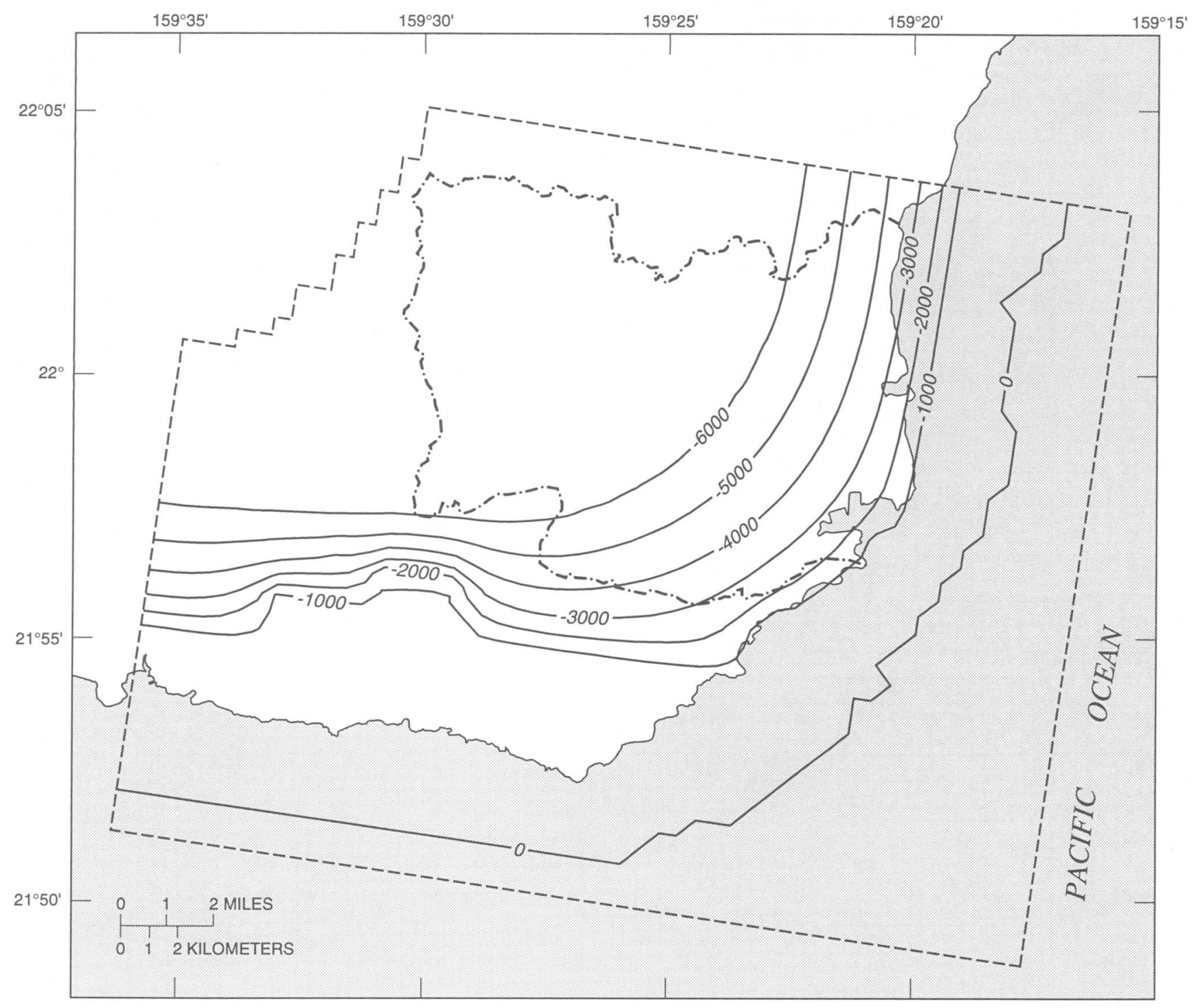

LOWER LAYER

\section{EXPLANATION}

- -1000 - LINE OF EQUAL ELEVATION OF MODEL-CALCULATED FRESHWATER-SALTWATER INTERFACE--Interval 1,000 feet. Datum is mean sea level

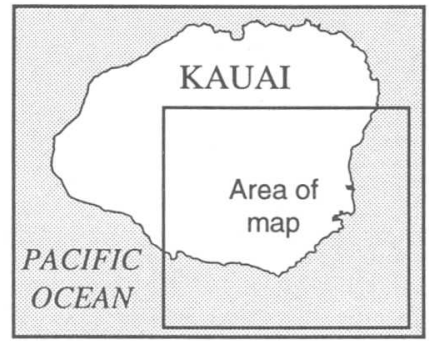

- - - - NO-FLOW BOUNDARY

$\cdot-\cdot \cdot \cdot-$ BOUNDARY OF SOUTHERN LIHUE BASIN

Figure 21. Simulated elevation of the freshwater/saltwater interface in the upper layer and lower layer of the numerical ground-water model of the southern Lihue Basin, Kauai, Hawaii--Continued. 


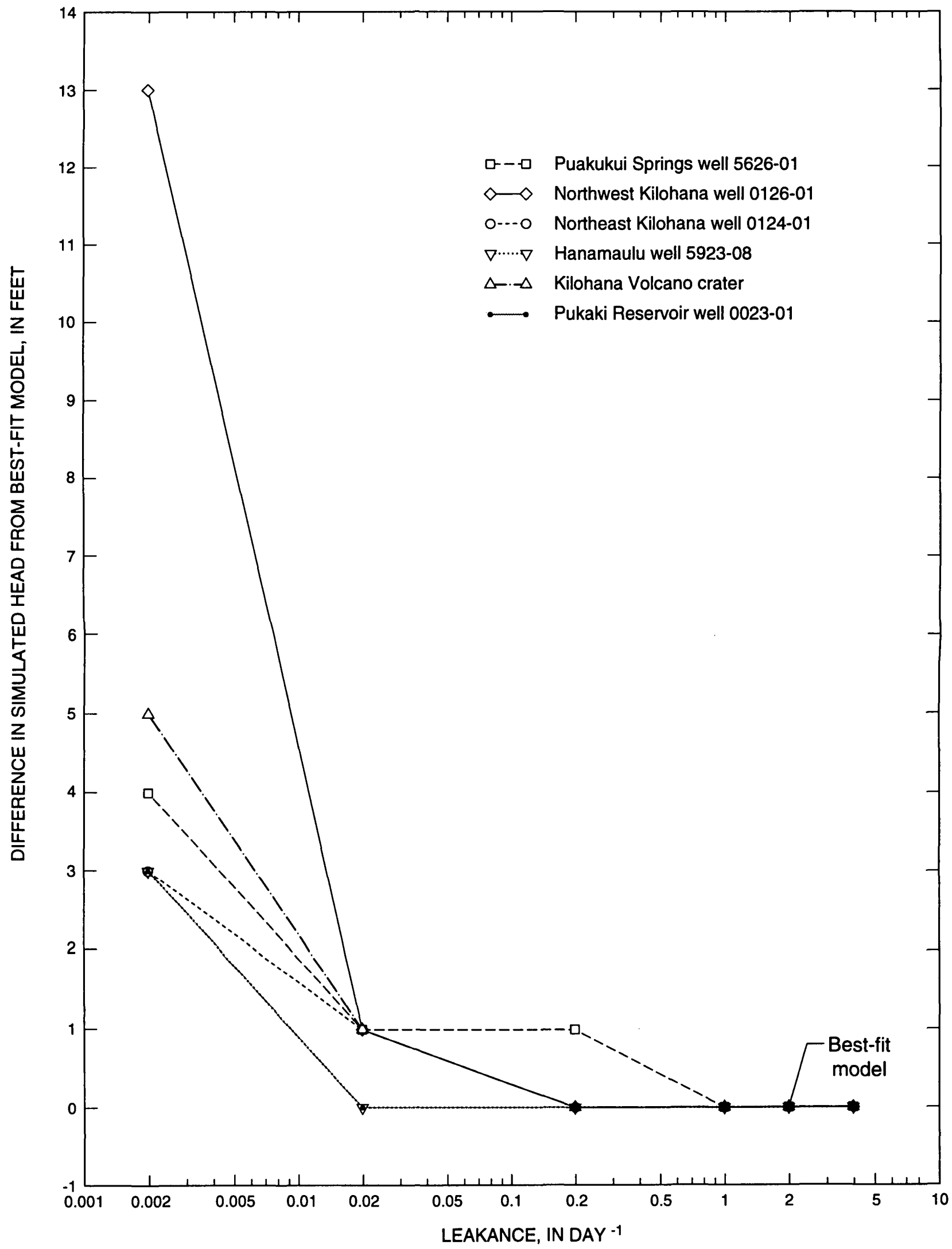

Figure 22. Variations of simulated head with streambed and ocean-floor leakance in the numerical ground-water model of the southern Lihue Basin, Kauai, Hawaii. 
of Haupu Ridge. The lack of substantial differences in water levels between the best-fit model and the nonwithdrawal simulations for most monitoring points indicates that the model is not sensitive to the uncertainties in the rate of ground-water withdrawal, and that the uncertainties will have little effect on the outcome.

Also, because water levels at the monitoring points are not affected much by the ground-water withdrawal, water levels measured at those points at any time can be used to create a best-fit steady-state model without consideration of transient effects of ground-water withdrawal.

In the best-fit model, the ratio of $K_{v}$ to $K_{h}$ is 1:500 in the Koloa Volcanics, 1:200 in the flank lava flows of the Waimea Canyon Basalt, and 1:100 in the dikeintruded lavas of the Waimea Canyon Basalt. Sensitivity of the model to uncertainties in these ratios was tested with (1) a simulation in which $K_{v}$ was halved (the ratios of $K_{v}$ to $K_{h}$ were doubled) and (2) a simulation in which $K_{v}$ was doubled (the ratios of $K_{v}$ to $K_{h}$ were halved). Differences in head between the test simulations and the best-fit model were less than $9 \mathrm{ft}$ at all monitoring points (table 7). The relatively small difference indicates that the model results are not significantly affected by uncertainties in anisotropy.

Sensitivity of the model to uncertainties in recharge was tested with a simulation having twice the value of recharge used in the best-fit model and another simulation having half the value of recharge of the bestfit model. Simulated water levels showed substantial sensitivity to changes in recharge (table 7). The difference between the water levels in the test simulations and best-fit model ranged from 9 to $142 \mathrm{ft}$. This analysis shows that uncertainties in recharge can have a significant effect on the model. The recharge calculations from Shade (1995a) which were used in the model are assumed to be correct; no estimate of uncertainty for the recharge values was given.

To determine the uniqueness of the distribution of hydraulic conductivities used in the best-fit model, the sensitivity of the model to variations in hydraulic conductivities also was tested. In order to keep the ratio of $K_{v}$ to $K_{h}$ the same, the value of $K_{v}$ was varied proportionally with $K_{h}$ in the test simulations. Hydraulic conductivities of the Koloa Volcanics, dike-confined Waimea Canyon Basalt, and flank lavas of the Waimea Canyon Basalt were doubled and halved in separate simulations. Simulated water levels in the southern
Lihue Basin are highly sensitive to the hydraulic conductivities of the Koloa Volcanics. Changes in hydraulic conductivities result in changes in the simulated horizontal ground-water gradient; thus, water levels at points farther inland, away from discharge areas, are more affected than areas that are closer to discharge points at the coast and where the lower reaches of streams converge (fig. 23). The hydraulic conductivities of the Koloa Volcanics in the best-fit model result in a close match of simulated and observed water levels. The sensitivity analysis shows that other values of hydraulic conductivity for the Koloa Volcanics will result in simulated water levels that do not match the observed water levels.

The model is apparently not sensitive to the hydraulic conductivities of the flank lava flows of the Waimea Canyon Basalt (table 7). This is expected, because the flank lava flows are far from the monitoring points of the model and were included only so that the no-flow boundaries on the periphery of the model would not affect the area of interest in the southern Lihue Basin. Most areas of the model inside the southern Lihue Basin are also not sensitive to the hydraulic conductivities of the dike-confined Waimea Canyon Basalt. Only the water level in well 5626-01 at the periphery of the southern Lihue Basin is substantially affected by changes in the hydraulic conductivities of the dike-confined Waimea Canyon Basalt. Although the model is not sensitive to hydraulic conductivities of the dike-confined Waimea Canyon Basalt, the hydraulic conductivity of this hydrogeologic unit is of less importance to the model than is the hydraulic conductivity of the Koloa Volcanics.

\section{Implications of the Numerical Model for Ground-Water Occurrence}

The numerical ground-water model shows that the low hydraulic conductivities estimated from aquifertest data in the Lihue Basin will result in steep horizontal ground-water gradients and water levels that are hundreds of feet above sea level in a fully saturated system. The model is consistent with drilling data that indicate that high water levels of the southern Lihue Basin are not perched. The variably saturated/unsaturated condition is unlikely to exist because the low-permeability rocks combined with a high influx of water cause ground water to saturate nearly to the ground surface. 


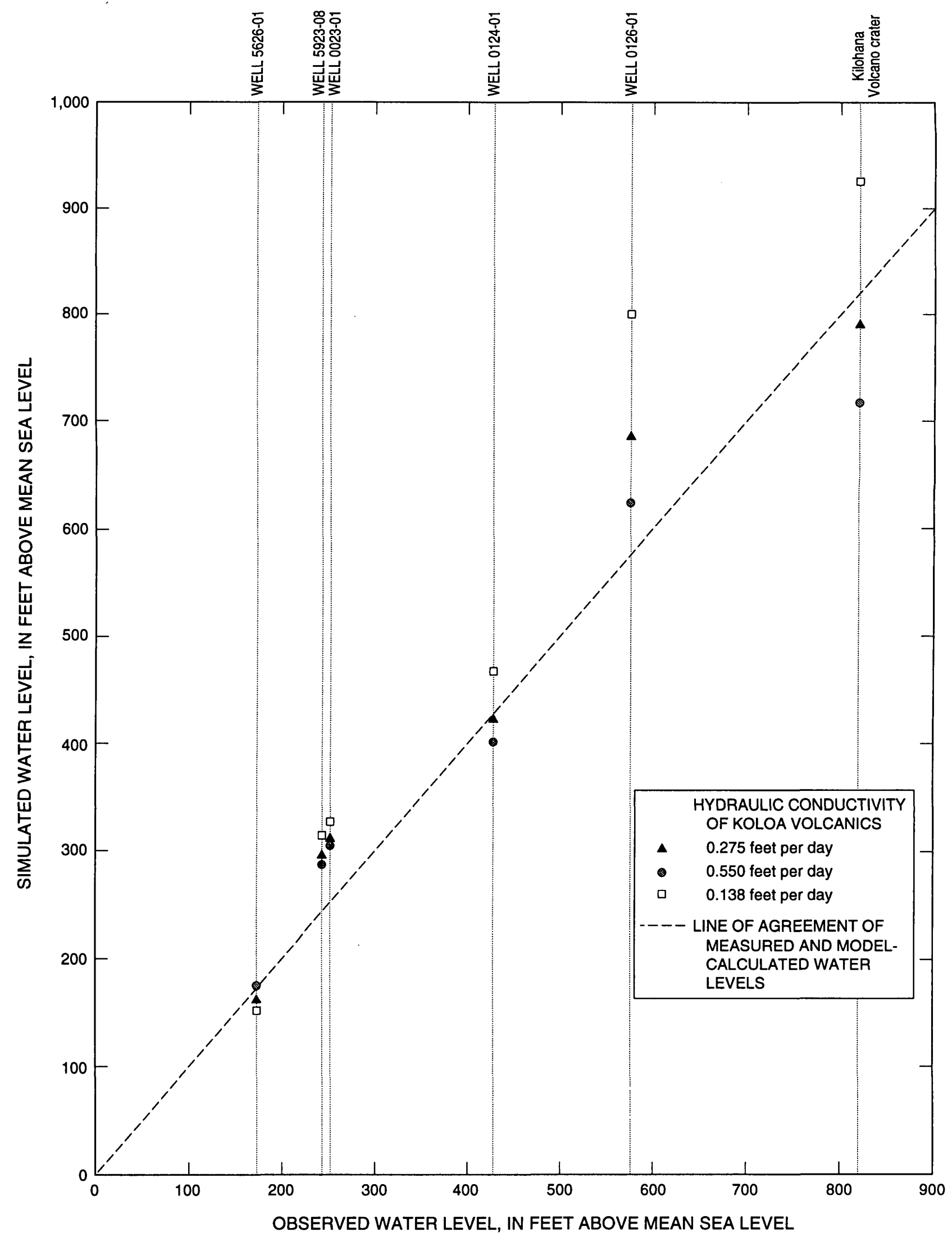

Figure 23. Observed water levels compared with simulated water levels for selected values of horizontal hydraulic conductivities $\left(K_{h}\right)$ in the Koloa Volcanics, southern Lihue Basin, Kauai, Hawaii. 
The model also shows the importance of streams in shaping the water table. Ground water is kept from saturating the rocks to the ground surface by the draining action of streams.

\section{CONCLUSIONS}

The ground-water system in the southern Lihue Basin is characterized by low-permeability rocks, water levels ranging from near sea level at the coast to hundreds of feet elevation inland, and a larger volume of ground-water discharge to streams than to the ocean. The Koloa Volcanics are extensive and thick and thus dominate the character of ground-water flow in the southern Lihue Basin. Substantial vertical head gradients exist in some parts of the Koloa Volcanics. In the northern part of the southern Lihue Basin, water levels declined gradually during drilling as the wells penetrated deeper into a downward-decreasing head gradient. This gradient results in downward movement of water as recharge reaches the water table and descends into the freshwater body. In other areas such as the Kilohana and Puhi well fields, water levels in wells declined in a stepwise fashion during drilling, which indicates that the aquifer has multiple layers with contrasting permeabilities in these areas. The abrupt drops in water levels correlate with transitions from thick sections of dense, low-permeability lava flows above to loosely consolidated, higher permeability rock below. Despite a few higher permeability layers, the overall horizontal hydraulic conductivity of the Koloa Volcanics is low: the average regional horizontal hydraulic conductivity estimated by the best-fit model is 0.275 foot per day, which is consistent with estimates from aquifer tests. The apparent higher permeabilities in some areas such as the Kilohana and Puhi well fields are of limited extent and the initial high yields of wells in this area will likely decrease as the effects of the ground-water withdrawal extend farther into the regional low-conductivity rocks of the Koloa Volcanics.

The Waimea Canyon Basalt, which crops out in ridges surrounding the southern Lihue Basin and underlies the Koloa Volcanics, is intruded by dikes that reduce the bulk permeability of the rocks. The best-fit numerical ground-water model and an aquifer test indicate that the horizontal hydraulic conductivity of the dike-intruded Waimea Canyon Basalt is about 1.11 feet per day. The frequency of dikes probably diminishes, and the bulk hydraulic conductivity correspondingly increases, to the south and west of the Lihue Basin.

When the large influx of water from recharge encounters the high resistance to flow provided by the low-permeability rock of the Koloa Volcanics and dikeintruded Waimea Canyon Basalt in the southern Lihue Basin, steep horizontal head gradients and high water levels in inland areas result. Water levels in the Waimea Canyon Basalt in the mountains at the western margin of the southern Lihue Basin are high because of the impounding effects of dikes and the overlying Koloa Volcanics; water levels in the center of the southern Lihue Basin are high because of the low permeability of the Koloa Volcanics. Ground water saturates nearly to the surface in most of the southern Lihue Basin.

Streams incising the Koloa Volcanics drain the upper part of the aquifer and keep the water levels just below the surface in most places. The streams thus play an important part in shaping the water table in the southern Lihue Basin. Gradients are steepest where the aquifer is drained by streams and flatter where there are few streams. Instantaneous ground-water discharge measurements, base-flow analyses, and numerical-groundwater-model simulations indicate that at least 62 percent of the ground-water discharge in the southern Lihue Basin occurs at streams and rivers; the remainder discharges to the ocean or is withdrawn by wells.

Data and analyses in this study indicate that the high water levels characteristic of the Lihue Basin are part of a completely saturated, not perched, groundwater system. High water levels persist in wells drilled to hundreds of feet below sea level. The numerical ground-water model shows that the low permeabilities consistent with estimates from aquifer tests in the southern Lihue Basin will result in high water levels in a fully saturated system. Because of the low regional horizontal hydraulic conductivity and high influx of water in the southern Lihue Basin, the rocks will become completely saturated nearly to the surface and the variably saturated/unsaturated condition is unlikely to develop.

\section{REFERENCES CITED}

Clague, D.A., and Dalrymple, G.B., 1988, Age and petrology of alkalic post-shield and rejuvenated-stage lava from Kauai, Hawaii: Contributions to Mineralogy and Petrology, v. 99, p. 202-218. 
Davis, R.T., 1960, Major streams of Kauai and their utilization: Honolulu, Hawaii, University of Hawaii, M.A. thesis, $159 \mathrm{p}$.

Department of Land and Natural Resources, 1962, Summary of drilling logs and pumping test for exploratory well no. 3 (USGS well no. 11), Lihue, Kauai, Hawaii: 19 p.

Essaid, H.I., 1990, The computer model SHARP, a quasithree-dimensional finite-difference model to simulate freshwater and saltwater flow in layered coastal aquifer systems: U.S. Geological Survey Water-Resources Investigations Report 90-4130, 181 p.

Fontaine, R.A., 1995, Evaluation of the surface-water quantity, surface-water quality, and rainfall data-collection programs in Hawaii, 1994: U.S. Geological Survey Water-Resources Investigations Report 95-4212, 125 p.

Feigenson, M.D., 1984; Geochemistry of Kauai volcanics and a mixing model for the origin of Hawaiian alkali basalts: Contributions to Mineralogy and Petrology, v. 87, p. 109-119.

Giambelluca, T.W., Nullet, M.A., and Schroeder, T.A., 1986, Rainfall atlas of Hawaii: State of Hawaii Department of Land and Natural Resources, Division of Water and Land Development Report R76, 267 p.

Gingerich, S.B., and Izuka S. K., 1997a, Construction, geologic log, and aquifer test of the Northwest Kilohana Monitor Well (State well 2-0126-01), Lihue, Kauai, Hawaii: U.S. Geological Survey Open-File Report 97$40,20 \mathrm{p}$.

--------, 1997b, Construction, geologic log, and aquifer tests of the Puakukui Springs Monitor Well (State well 2 5626-01), Lihue, Kauai, Hawaii: U.S. Geological Survey Open-File Report 97-38, 18 p.

Hawaii State Department of Land and Natural Resources, 1990, State water resources protection plan: Hawaii State Department of Land and Natural resources.

Holcomb, R.T., Reiners, P.W., Nelson, B.K., and Sawyer, N.E., 1997, Evidence for two shield volcanoes exposed on the Island of Kauai, Hawaii: Geology, v. 25, no. 9, p. 811-814.

Hunt, C.D., Jr., 1996, Geohydrology of the island of Oahu, Hawaii: U.S. Geological Survey Professional Paper 1412-B, 54 p.

Izuka S. K., and Gingerich, S.B., 1997a, Construction, geologic $\log$, and aquifer tests of the Hanamaulu Monitor Well (State well 2-5923-08), Lihue, Kauai, Hawaii: U.S. Geological Survey Open-File Report 97-36, 23 p.

--------, 1997b, Construction, geologic log, and aquifer test of the Northeast Kilohana Monitor Well (State well 20124-01), Lihue, Kauai, Hawaii: U.S. Geological Survey Open-File Report 97-37, 23 p.

-.----, 1997c, Construction, geologic log, and aquifer test of the Pukaki Reservoir Monitor Well (State well 2-
0023-01), Lihue, Kauai, Hawaii: U.S. Geological Survey Open-File Report 97-41, 22 p.

-.-----, 1997d, Construction and geologic log of the South Wailua Monitor Well (State well 2-0121-01), Lihue, Kauai, Hawaii: U.S. Geological Survey Open-File Report 97-38, 14 p.

Kauahikaua, Jim, 1993, Geothermal characteristics of the hydrothermal systems of Kilauea Volcano, Hawai'i: Geothermics, v. 22, no. 4, p. 271-299.

Kivroy, H.L., Baker, M., and Moe, E.E., 1965, A reconnaissance gravity survey of the island of Kauai: Pacific Science, v. 19, p. 354-358.

Langenheim, V.A.M., and Clague, D.A., 1987, Stratigraphic framework of volcanic rocks of the Hawaiian Islands: Volcanism in Hawaii, U.S. Geological Survey Professional Paper 1350, v. 1, p. 55-84.

Larrison, G.K., 1915, Water resources of Hawaii, 1913: U.S. Geological Survey Water-Supply Paper 373, 190 p.

Maaloe, S., James, S., and Smedley, D., 1992, The Koloa volcanic suite of Kauai, Hawaii: Journal of Petrology, v. 33, part 4, p. 761-748.

Macdonald, G.A., 1968, Composition and origin of Hawaiian lavas: Geological Society of America Memoirs, v. 116, p. 477-522.

-.-----, Davis, D.A., and Cox, D.C., 1960, Geology and ground-water resources of the island of Kauai, Hawaii: Hawaii Division of Hydrography, Bulletin 13, 212 p.

Martin, W.F., and Pierce, C.H., 1913, Water resources of Hawaii, 1909-1911: U.S. Geological Survey WaterSupply Paper 318, 552 p.

Moore, J.G., Clague, D.A., Holcomb, R.T., Lipman, P.W., Normark, W.R., and Torresan, M.E., 1989, Prodigious submarine landslides on the Hawaiian Ridge: Journal of Geophysical Research, v. 94, no. B12, p. 17465-17484.

Pierce, C.H., and Larrison, G.K., 1914, Water resources of Hawaii, 1912: U.S. Geological Survey Water-Supply Paper 336, 392 p.

Shade, P.J., 1995a, Water budget for the island of Kauai, Hawaii: U.S. Geological Survey Water-Resources Investigations Report 95-4128, 25 p.

--------, 1995b, Estimated water use in 1990 for the island of Kauai, Hawaii: U.S. Geological Survey WaterResources Investigations Report 93-4180, 23 p.

Soroos, R.L., 1973, Determination of hydraulic conductivity of some Oahu aquifers with step-drawdown test data: Honolulu, Hawaii, University of Hawaii, M.S. Thesis, 239 p.

Souza, W.R., and Voss, C.I., 1987, Analysis of an anisotropic coastal aquifer system using variable-density flow and solute transport simulation: Journal of Hydrology, v. 92, p. $17-41$. 
State of Hawaii, 1991, The population of Hawaii, 1990: State of Hawaii Department of Business and Economic Development and Tourism, Statistical Report 219, Honolulu, Hawaii, 28 p.

Stearns, H.T., 1946, Geology of the Hawaiian Islands: Hawaii Division of Hydrography, Bulletin 8, 112 p.

-.----, 1985, Geology of the State of Hawaii (2d ed.): Palo Alto, Calif., Pacific Books, 335 p.

Takasaki K.J., and Mink, J.F., 1985, Evaluation of major dike-impounded ground-water reservoirs, island of Oahu: U.S. Geological Survey Water-Supply Paper 2217, $77 \mathrm{p}$.

Takasaki, K.J., Hirashima, G.T., and Lubke, E.R., 1969, Water resources of windward Oahu: U.S. Geological Survey Water-Supply Paper 1894, 119 p.

U.S. Geological Survey, 1983a, Hanapepe Quadrangle, Hawaii-Kauai Co., island of Kauai: 7.5-minute series (topographic map), 1:24,000 scale.

--------, 1983b, Koloa Quadrangle, Hawaii-Kauai Co., island of Kauai: 7.5-minute series (topographic map), $1: 24,000$ scale.

-------, 1983c, Kapaa Quadrangle, Hawaii-Kauai Co., island of Kauai: 7.5-minute series (topographic map), 1:24,000 scale.

--.-.-.-., 1983d, Lihue Quadrangle, Hawaii-Kauai Co., island of Kauai: 7.5-minute series (topographic map), 1:24,000 scale.

..-.-.-.-., 1983e, Waialeale Quadrangle, Hawaii-Kauai Co., island of Kauai: 7.5-minute series (topographic map), $1: 24,000$ scale.

--------, 1983f, Waimea Quadrangle, Hawaii-Kauai Co., island of Kauai: 7.5-minute series (topographic map), $1: 24,000$ scale.

Wahl, K.L., and Wahl,T.L., 1995, Determining the flow of Comal Springs at New Braunfels, Texas: Proceedings of Texas Water '95, A Component Conference of the First International Conference on Water Resources Engineering, American Society of Civil Engineers, August 1617, 1995, San Antonio, Texas, p. 77-86.

Walker, G.P.L., 1987, The dike complex of Koolau Volcano, Oahu: internal structure of a Hawaiian rift zone: Volcanism In Hawaii, U.S. Geological Survey Professional Paper 1350, v. 2, p. 961-993.

Wilson Okamoto and Associates, Inc., 1976, Lihue water system source development and investigation study and report, $85 \mathrm{p}$. 


\section{APPENDIX}

\section{MODIFICATIONS TO THE PROGRAM SHARP TO ACCOUNT FOR CHANGING SATURATED THICKNESS IN THE FRESHWATER AND SALTWATER DOMAINS}

The SHARP program (Essaid, 1990) is used to create quasi-three-dimensional, block-centered-finite-difference numerical models of ground-water flow. The program allows simulation of coupled freshwater/saltwater flow, which is useful for simulating the stratified freshwater/saltwater systems of ocean-island and coastal aquifers. The overlying freshwater and underlying saltwater are simulated as immiscible domains and the contact between the freshwater and saltwater domains is simulated as a sharp interface. The SHARP program user specifies, among other things, aquifer properties, freshwater and saltwater properties, and initial freshwater head. The program computes, by iterative solution, the heads and the position of the freshwater/saltwater interface at specified intervals of time (time steps) since the initial condition. Because of the nature of the equations involved in simulating coupled freshwater/saltwater flow, the SHARP program runs only in a transient mode in which head and interface position are calculated at each time step during the simulation. For a steady-state problem, the program runs in the transient mode until the head change between successive time steps is smaller than a user-specified steady-state criterion, at which point the program considers steady state to have been achieved. In reaching a solution for a time step, the SHARP program recalculates head and interface position at each iteration within the time step. Transmissivity, which governs horizontal flow and is a function of saturated thickness, is also recalculated at each iteration because saturated thickness varies with head (in unconfined cells) and interface position.

Vertical flow through the top of cells in the uppermost layer of a model is a function of vertical leakance $(l)$ which is given by (fig. A1):

$$
l=\frac{K}{b}
$$

where

$$
\begin{aligned}
l= & \text { vertical leakance }\left(\mathrm{T}^{-1}\right), \\
K= & \text { vertical hydraulic conductivity }(\mathrm{L} / \mathrm{T}) \text {, and } \\
b= & \text { the vertical flow distance (for freshwater flow, } b \text { is the distance between the center of the freshwater- } \\
& \text { saturated part of the cell and top of the cell; for saltwater flow, } b \text { is the distance between the center } \\
& \text { of the saltwater-saturated portion of the cell and top of the cell) (L). }
\end{aligned}
$$

In multi-layer models, vertical flow also occurs between aquifer layers. Because two aquifer layers are involved, $l$ is the serial sum of the separate leakance components of the upper and lower cells:

$$
l=\frac{1}{\frac{b_{1}}{K_{1}}+\frac{b_{2}}{K_{2}}}
$$

where

$b_{1}=$ half the thickness of freshwater (for freshwater cells) or saltwater (for saltwater cells) in the lower cell (L),

$K_{l}=$ vertical hydraulic conductivity in the lower cell $(\mathrm{L} / \mathrm{T})$,

$b_{2}=$ half the thickness of freshwater (for freshwater cells) or saltwater (for saltwater cells) in the upper cell (L), and

$K_{2}=$ vertical hydraulic conductivity in the upper cell $(\mathrm{L} / \mathrm{T})$. 
A

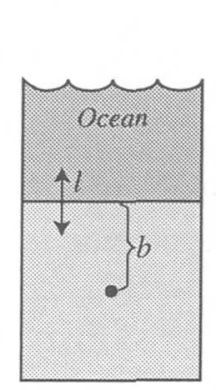

B

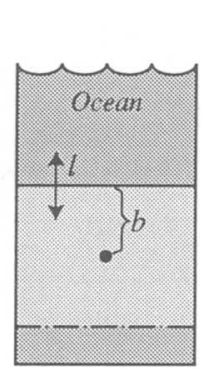

C

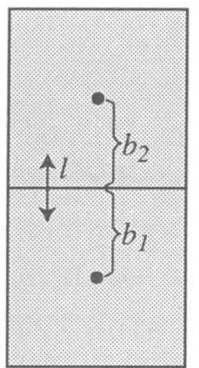

D

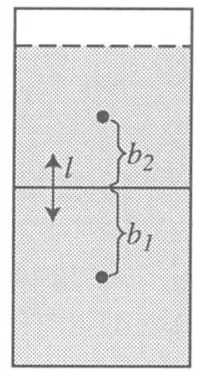

$\mathrm{E}$

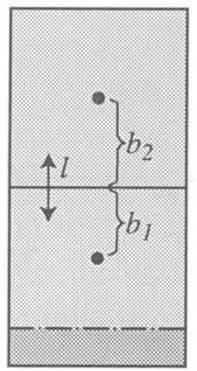

$\mathrm{F}$

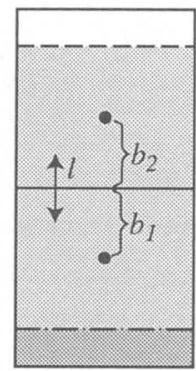

EXPLANATION

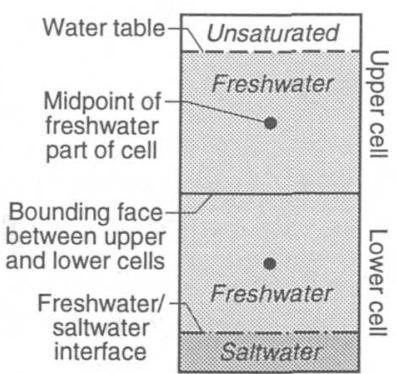

Figure A1. Variation of vertical distances $(b)$ used to calculate vertical leakance $(l)$ in cells: (A) non-variable $b$ in a single-layer model cell completely saturated with fresh water, (B) variable $b$ in a single-layer model cell containing the freshwater/saltwater interface, $(C)$ non-variable vertical distances in upper $\left(b_{2}\right)$ and lower $\left(b_{1}\right)$ cells of a two-layer where both upper and lower cells are completely saturated with fresh water, (D) variable $b_{2}$ and non-variable $b_{1}$ in a two-layer model where the upper cell has a water table (is unconfined) and the lower layer is completely saturated with freshwater, (E) non-variable $b_{2}$ and variable $b_{1}$ in a two-layer model where the upper cell is completely saturated with freshwater and the lower cell has the freshwater/saltwater interface, and $(\mathrm{F})$ variable $b_{1}$ and $b_{2}$ in a two-layer model where the upper cell has a water table and the lower cell has the freshwater/saltwater interface.

The value of $l$ should change as values of $b$ in equation A1 and $b_{1}$ and $b_{2}$ in equation A2 change as the program recomputes interface depth at each iteration. However, the value of $l$ in the original version of SHARP is not recomputed at each iteration because the vertical-flow aspect of SHARP was originally designed to simulate situations where the effects of thin, low-permeability confining layers dominate vertical flow (Essaid, 1990). With confining layers, the value of $l$ for flow through the top of cells in the uppermost layer of a model is given by:

$$
l=\frac{1}{\frac{b_{a}}{K_{a}}+\frac{b_{c}}{K_{c}}}
$$

where

$$
\begin{aligned}
& \frac{b_{a}}{K_{a}}=\text { reciprocal of the leakance due to the cell (L), and } \\
& \frac{b_{c}}{K_{c}}=\text { reciprocal of the leakance due to the confining layer }(\mathrm{L}) .
\end{aligned}
$$

The value of $l$ between two cells separated by a confining layer is given by:

$$
l=\frac{1}{\frac{b_{1}}{K_{1}}+\frac{b_{c}}{K_{c}}+\frac{b_{2}}{K_{2}}}
$$

where

$$
\begin{aligned}
& \frac{b_{1}}{K_{1}}=\text { reciprocal of the leakance due to the lower cell }(\mathrm{L}), \text { and } \\
& \frac{b_{2}}{K_{2}}=\text { reciprocal of the leakance due to the upper cell }(\mathrm{L}) .
\end{aligned}
$$


If the vertical hydraulic conductivity of a confining layer is much lower than the vertical hydraulic conductivities of the cells, then equations $\mathrm{A} 3$ and $\mathrm{A} 4$ reduce to

$$
l \cong \frac{K_{c}}{b_{c}},
$$

that is, the total $l$ is dominated by the confining layer. The value of $b_{c}$ and therefore $l$ of the confining layer stay constant, even if the water-table or interface positions change in the overlying and underlying cells, because the confining layer is thin and will not likely contain either the water table or interface. The confining-layer conceptualization therefore does not require recalculation of $l$ at each iteration. In the original version of SHARP, the program user computes $l$, based solely on the confining unit, externally from the program, enters the values into the program input file, and the program uses the single value of $l$ assigned to each cell to compute both freshwater and saltwater vertical flow throughout the length of the simulation. This conceptualization, however, limits the application of the original version of SHARP to simulations where confining units are present. In the more general case where a confining layer is absent, computation of $l$ must consider the changes of $b, b_{1}$, and $b_{2}$ as a result of changes in water-table and interface elevations at successive iteration steps.

\section{DESCRIPTION OF PROGRAM MODIFICATION}

To address the case of variable $l$, the original SHARP program was modified to recalculate $l$ for specified cells at each iteration. In the modified SHARP program, the value of $K$ for each layer is specified by the program user, $b$ for each layer is recalculated from the water-table and interface elevations at each iteration, and $l$ is recalculated by the program on the basis of the recalculated values of $b$.

\section{Leakance Through Top of Uppermost Model Layer}

In single-layer models and the uppermost layer of multi-layer models, vertical flow occurs between confinedaquifer cells and the simulated ocean, springs, streams, or lakes overlying the cells. Similar vertical flow occurs between lower layers of multi-layer models and the ocean when overlying layers of a model pinch out, thus exposing the underlying layers to the ocean. In these cases, $l$ is calculated from equation A1. The value of $b$ for a confinedaquifer cell depends on whether or not the interface is located in the cell and whether freshwater, saltwater, or a combination of freshwater and saltwater underlies the upper face of the cell.

If the upper face of a confined-aquifer cell is completely underlain by freshwater, the value of $b$ is equal to half the freshwater thickness. Freshwater thickness is equal to the distance between the top of the cell and either (1) the bottom of the cell if the cell is completely saturated with freshwater (fig. A2A), or (2) the interface if the cell contains the interface (fig. A2B). If the upper face of a confined-aquifer cell is completely underlain by saltwater, the value of $b$ is equal to half the saltwater thickness. In this case, the entire cell is saturated with saltwater, therefore the saltwater thickness is equal to the distance between the top and bottom of the cell (fig. A2C).

If the interface intersects the upper face of a confined-aquifer cell, the upper face is underlain partly by freshwater and partly by saltwater, and $b$ is computed on the basis of combined freshwater and saltwater thickness scaled respectively by the proportions of the area of the upper face underlain by freshwater and saltwater (fig. A3). Freshwater thickness is equal to the distance between the top of the cell and the interface; saltwater thickness is equal to the distance between the interface and the bottom of the cell (computation of the interface elevation in a cell with a dipping interface is explained by Essaid, 1990). Freshwater thickness is multiplied (scaled) by the proportion of the area of upper face underlain by freshwater and saltwater thickness is multiplied by the proportion underlain by saltwater. The value of $b$ is equal to half the sum of the scaled freshwater and saltwater thicknesses (fig. A3): 
A

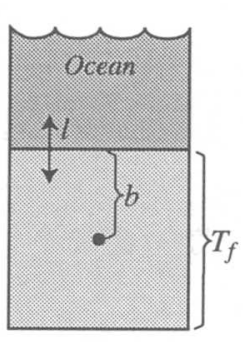

B
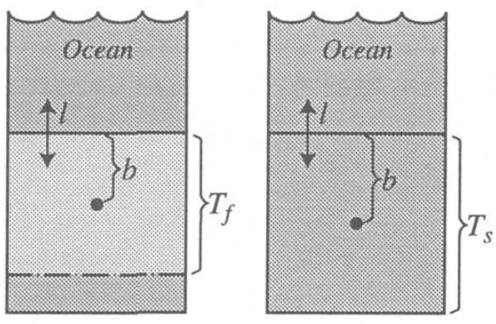

EXPLANATION

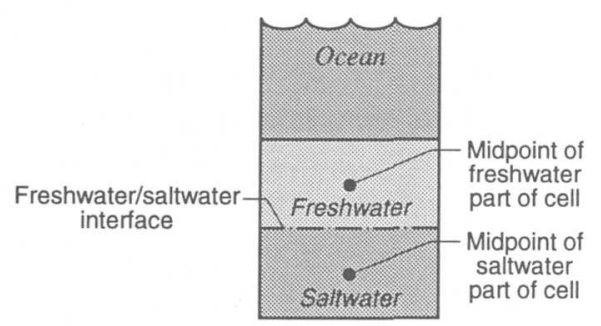

Figure A2. Vertical distances $(b)$ used by the modified SHARP program to calculate vertical leakance $(l)$ in a (A) confined cell fully saturated with freshwater, (B) confined cell containing the freshwater/saltwater interface, and (C) confined cell fully saturated with saltwater, in single-layer models or the uppermost layer of multi-layer models. The value of $b$ is one half the thickness of freshwater $\left(T_{f}\right)$ in $(\mathrm{A})$ and $(\mathrm{B})$, and one half the saltwater thickness $\left(T_{s}\right)$ in $(\mathrm{C})$.

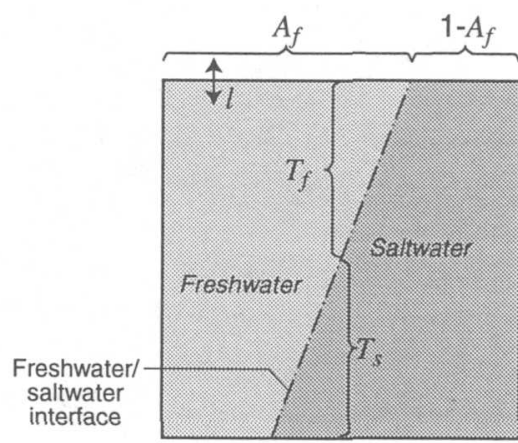

$$
\begin{aligned}
& b=0.5\left[T_{f}\left(A_{f}\right)+T_{s}\left(1-A_{f}\right)\right] \\
& \text { where: }
\end{aligned}
$$

$T_{f}=$ Thickness of freshwater

$A_{f}=$ Proportion of upper face underlain by freshwater

$T_{s}=$ Thickness of saltwater

Figure A3. Vertical distances $(b)$ used by the modified SHARP program to calculate vertical leakance $(l)$ in a confined cell in which the freshwater/saltwater interface intersects the upper face of the cell.

$$
b=0.5\left(T_{f}\left(A_{f}\right)+T_{s}\left(1-A_{f}\right)\right)
$$

where

$T_{f}=$ thickness of freshwater (L),

$A_{f}=$ proportion of upper face underlain by freshwater (L), and

$T_{s}=$ thickness of saltwater $(\mathrm{L})$.

This yields an average interface position which is then used to compute $l$. The resulting value of $l$ is an approximation and is not precisely correct for either the saltwater or freshwater domains.

\section{Leakance Between Model Layers}

In multi-layer models, vertical flow occurs not only through the top of the uppermost layer but also between aquifer layers. Because two aquifer layers are involved, $l$ is the serial sum of the separate leakance components of the upper and lower cells (equation A2). 

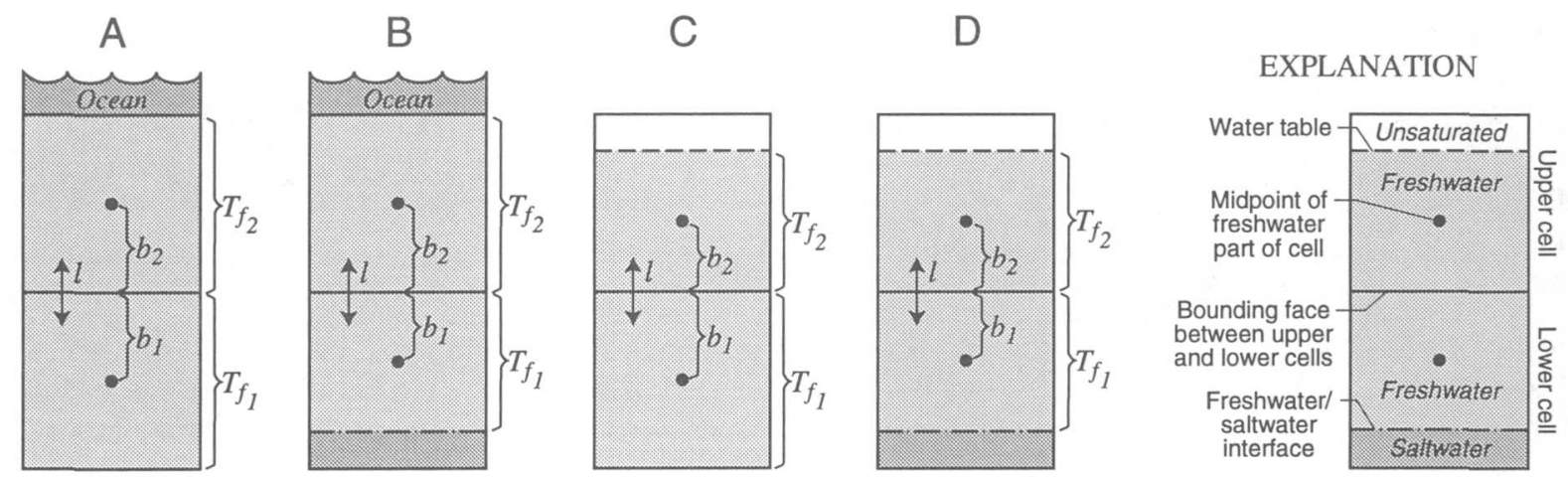

Figure A4. Vertical distances used to calculate vertical freshwater leakance $(l)$ between two cells, one overlying the other. The vertical distance in the lower cell $\left(b_{1}\right)$ is one half the thickness of freshwater in the lower cell, $\left(T_{f_{l}}\right)$, and the vertical distance in the upper cell $\left(b_{2}\right)$ is one half the thickness of freshwater in the upper cell, $\left(T_{f_{2}}\right)$.

If the bounding face between the upper and lower cells is completely underlain and overlain by freshwater, only freshwater can be exchanged between the cells so $b_{1}$ and $b_{2}$ are computed on the basis of freshwater thickness (fig. A4). The value of $b_{1}$ is equal to half the distance between the top of the lower cell and either (1) the bottom of the cell if the cell is completely saturated with freshwater (fig. A4A, A4C) or (2) the interface if the cell contains the interface (fig. A4B, A4D). The value of $b_{2}$ is equal to half the distance between the base of the upper cell and either (1) the top of the cell for confined cells (fig. A4A, A4B), or (2) the water table for unconfined cells (fig. A4C, A4D).

If the bounding face between the upper and lower cells is completely underlain and overlain by saltwater, $b_{1}$ and $b_{2}$ are computed on the basis of saltwater thickness (fig. A5). The lower cell in this case must be entirely saturated with saltwater so the value of $b_{1}$ is equal to half the distance between the top and bottom of the lower cell. The value of $b_{2}$ is equal to half the distance between the base of the upper cell and either (1) the top of the upper cell if the upper cell is completely saturated with saltwater (fig. A5A), (2) the interface if the upper cell contains the interface (fig. A5B, A5C), or (3) the top of the water table if the upper cell is unconfined and completely filled with saltwater (fig. A5D).

If the interface intersects the bounding face between the upper and lower cells, the bounding face is intersected by both freshwater and saltwater, and $b_{1}$ and $b_{2}$ are computed on the basis of both freshwater and saltwater thickness scaled by the respective proportions of freshwater area and saltwater area on the bounding face (fig. A6A). However, because of the discretization required by SHARP, the intersection of the interface may be artificially discontinuous across the bounding face (fig. A6B). To overcome this artifact of discretization, the freshwater areas above and below the bounding face are averaged, as are the saltwater areas above and below the bounding face. This yields an average interface position which is then used to compute $b_{1}$ and $b_{2}$ (fig. A7):

$$
b_{1}=0.25\left(T_{f_{1}}\left(A_{f_{1}}\right)+T_{s_{1}}\left(1-A_{f_{1}}\right)+T_{s_{1}}\left(A_{s_{2}}\right)+T_{f_{1}}\left(1-A_{s_{2}}\right)\right)
$$

and

$$
b_{2}=0.25\left(T_{f_{2}}\left(A_{f_{1}}\right)+T_{s_{2}}\left(1-A_{f_{1}}\right)+T_{s_{2}}\left(A_{s_{2}}\right)+T_{f_{2}}\left(1-A_{s_{2}}\right)\right)
$$


A

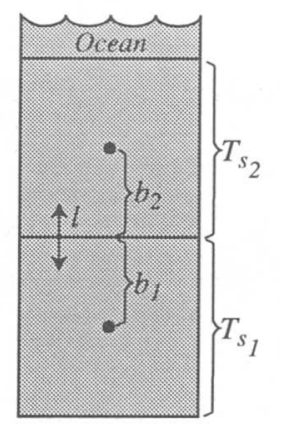

B

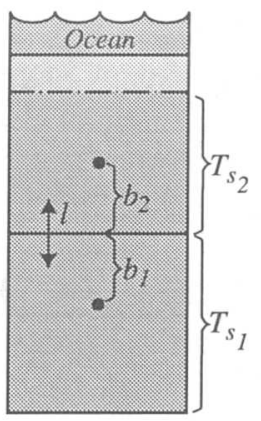

C

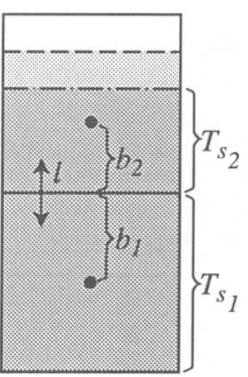

$\mathrm{D}$

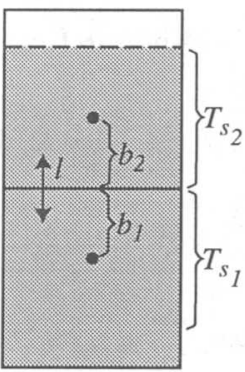

EXPLANATION

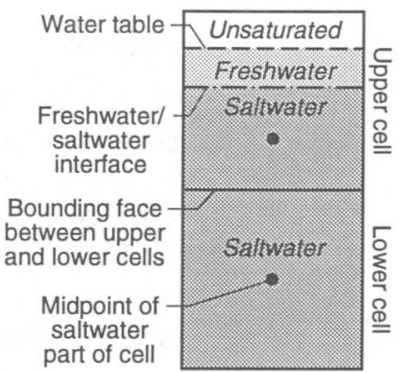

Figure A5. Vertical distances used to calculate vertical saltwater leakance $(l)$ between two cells, one overlying the other. The vertical distance in the lower cell $\left(b_{1}\right)$ is one half the thickness of saltwater in the lower cell, $\left(T_{s_{J}}\right)$, and the vertical distance in the upper cell $\left(b_{2}\right)$ is one half the thickness of saltwater in the upper cell, $\left(T_{s_{2}}\right)$.

A

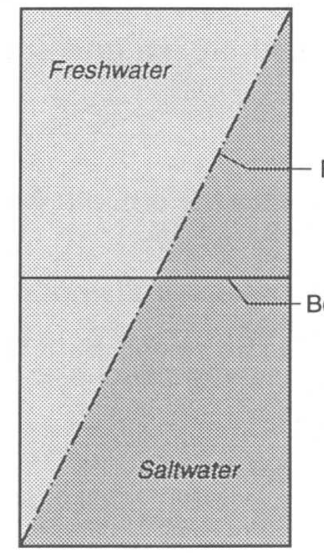

Theoretical interface: continuous across bounding face

Figure A6. Difference between theoretical and discretized freshwater/saltwater interfaces crossing the boundary between upper and lower layers.
B

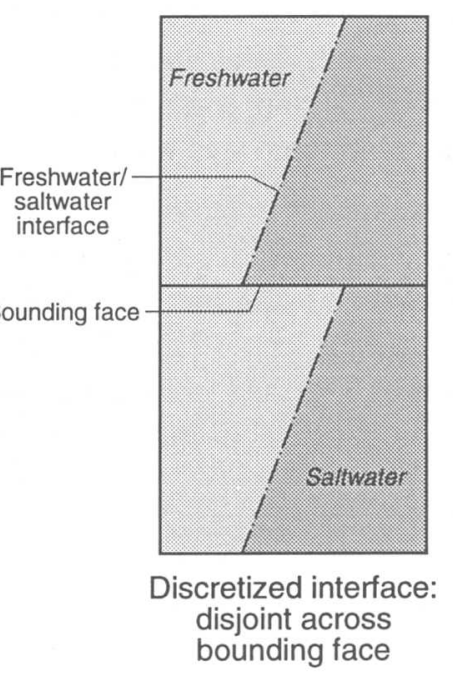


where

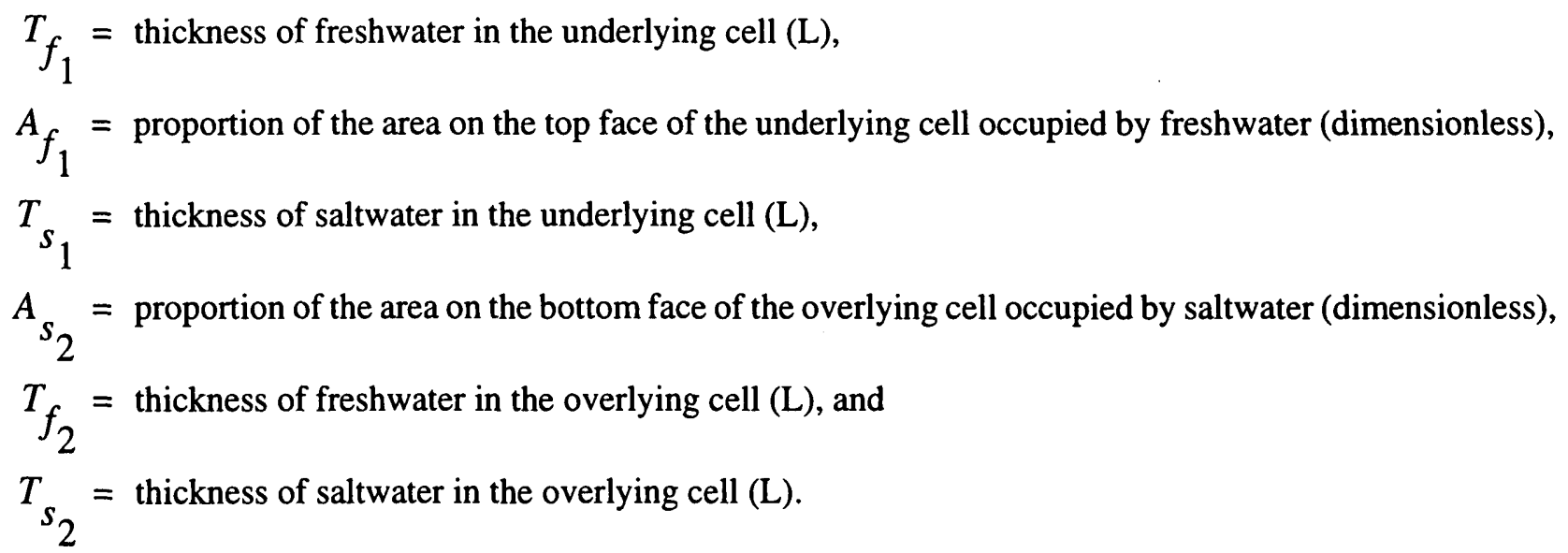

The results of equations $\mathrm{A} 7$ and $\mathrm{A} 8$ are used in equation $\mathrm{A} 2$ to obtain $l$, which, as discussed in the previous section, is an approximation and not precisely correct for either the saltwater or freshwater domains.

\section{Limitations of the Modified Program}

During each iteration, the modified SHARP program computes one value of $l$ at each bounding face between superimposed cells or the upper face of confined cells in the uppermost layer. In cases where only freshwater flows vertically, $l$ is computed on the basis of freshwater thickness; in cases where only saltwater flows vertically, $l$ is computed on the basis of saltwater thickness. However, using a single value of $l$ for cells in which both freshwater and saltwater flow vertically is contrary to the concept of separate freshwater and saltwater flow domains of the SHARP program. The limitation is inherited from the structure of the original SHARP program where only one leakance value was specified for each bounding face, regardless of whether freshwater, saltwater, or both flowed vertically across the face.

Where both freshwater and saltwater flow vertically, the value of $l$ computed by the modified SHARP program is an average of the separate saltwater and freshwater $l$ values, computed on the basis of the respective freshwater and saltwater thicknesses, and weighted by the respective saltwater and freshwater areas on the bounding face between cells (or the upper face of cells in the uppermost layer). The resulting value of $l$ is therefore not precisely correct for either the saltwater or freshwater domains, but constitutes a compromise that cannot be avoided without rewriting the SHARP program to allow computation of separate saltwater $l$ and freshwater $l$.

In the modified SHARP program described here, the single value of $l$ is weighted more toward the domain with the larger area impinging upon the bounding face, thus the vertical flow of this domain will be more precisely computed. A less-precise vertical flow will be computed for the smaller domain, but because this domain constitutes a smaller proportion of the total vertical flow, the associated errors will be small. The effect of the errors on most models as a whole will be made even smaller because the errors occur only at the few cells where the freshwater domain pinches out towards the saltwater domain or the saltwater domain pinches out in the direction of the freshwater domain.

\section{CHANGES TO PROGRAM CODE}

The SHARP program was modified to recompute $l$ at each iteration by making the following changes to the original SHARP program code (the original SHARP program as well as the program modifications described here, are written in FORTRAN 77). Table Al summarizes the new variable and array names used in the SHARP program modifications. 
Table A1. Definition of selected variables and arrays from the modified SHARP program

\begin{tabular}{ll}
$\begin{array}{c}\text { Name of variable } \\
\text { or array }\end{array}$ & \\
\hline AQL & Array of computed vertical leakances \\
AQLI & Initial vertical-leakance array \\
BATH & Bathymetry (elevation of the top of a cell overlain directly by the ocean) \\
BK & Vertical distance used to compute leakance in underlying layer \\
BKP1 & Vertical distance used to compute leakance in overlying layer \\
FAREA & Proportion of the area of the top face of a cell underlain by freshwater \\
FKV & Freshwater vertical hydraulic conductivity \\
FKX & Hydraulic conductivity in the $x$ direction of the model (also defines active/inactive cells and upper-layer cells \\
& that pinch out) \\
SAREA & Proportion of the area of the bottom face of a cell overlain by saltwater \\
THF & Freshwater thickness \\
THS & Saltwater thickness \\
\hline
\end{tabular}

The following lines were substituted for the corresponding lines in the original program. These modified lines create two new arrays, AQLI and FKV, that will be needed in the modified program.

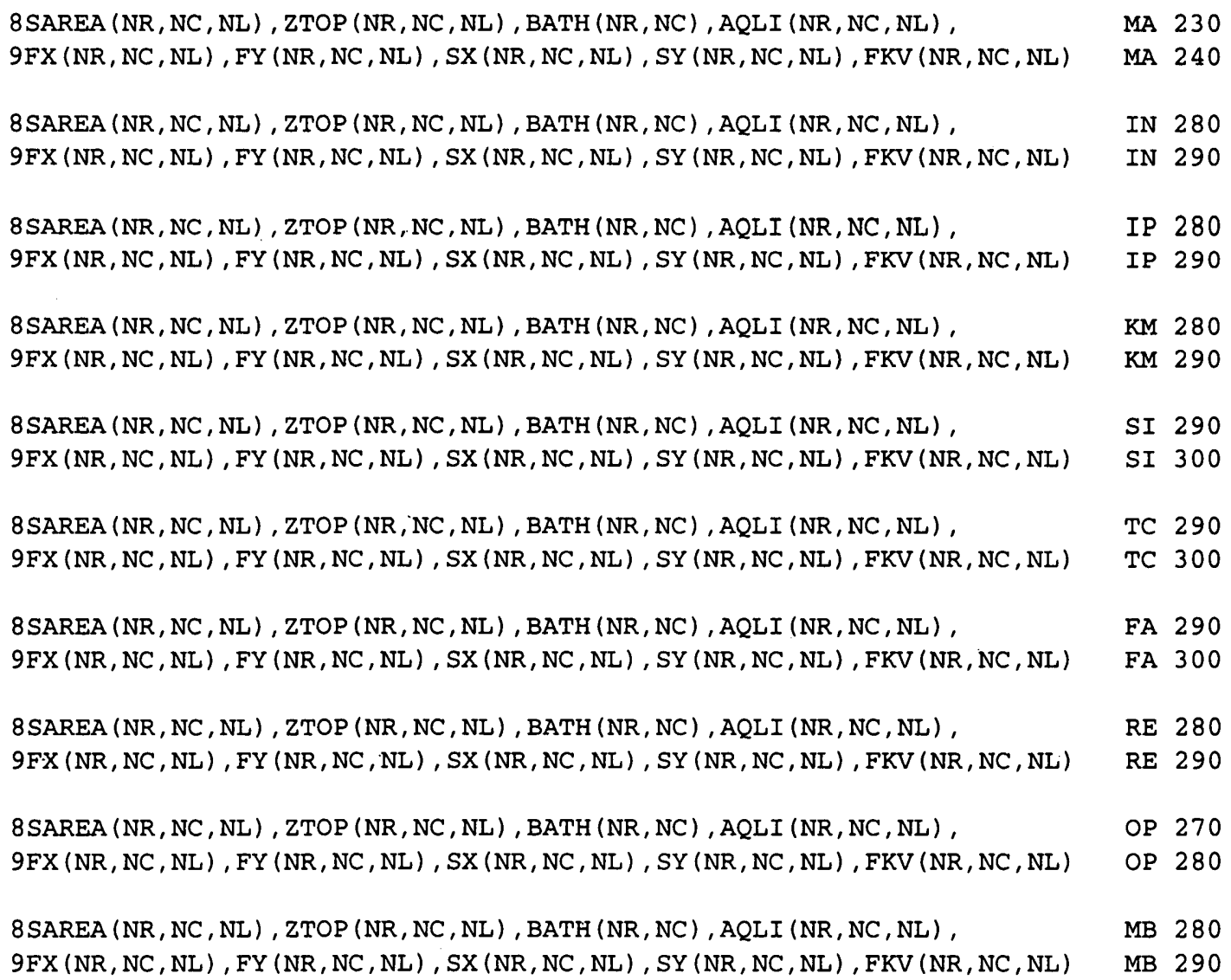

The following line was inserted between MA 820 and MA 830 of the original program to eliminate anomalously large saltwater heads in lower-layer cells where the overlying layer has pinched out, exposing the underlying layer to the ocean. 
The following new lines were inserted into the original SHARP program as indicated to recalculate aquifer leakance at each iteration:

(1) The following lines were inserted between IN1360 and IN1370 of the original program.

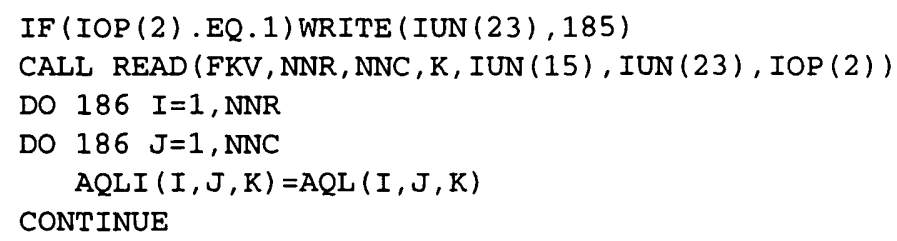

186 CONTINUE

(2) The following line was inserted between IN2180 and IN2190 of the original program.

185 FORMAT (/' VERTICAL HYDRAULIC CONDUCTIVITY')

DS0110496

(3) The following lines were inserted between SI 800 and SI 810 of the original program.

$\mathrm{C}$

$\mathrm{C}$

C
DSO110496 DS0111996 DSO110496 DS0110496 DSO110496 DS0110496 DSO111996 DSO111996 DSO110496 DS0110496 DS0110496 DS0110496 DS0110496 DS0110496 DS0110496 DSO110496 DSO110496 DSO110496 DSO110496 DSO110496 DSO110496 DS0110496 DSO110496 DS0110496 DSO110496 DS0110496 DS0110496 DS0111996 DSO110496 DS0110496 DSO110496 DS0111996 DSO111996 DS0111996 DSO111996 DSO110496 DS0110496 DS0110496 DSO110496 
PLAN VIEW OF GRID
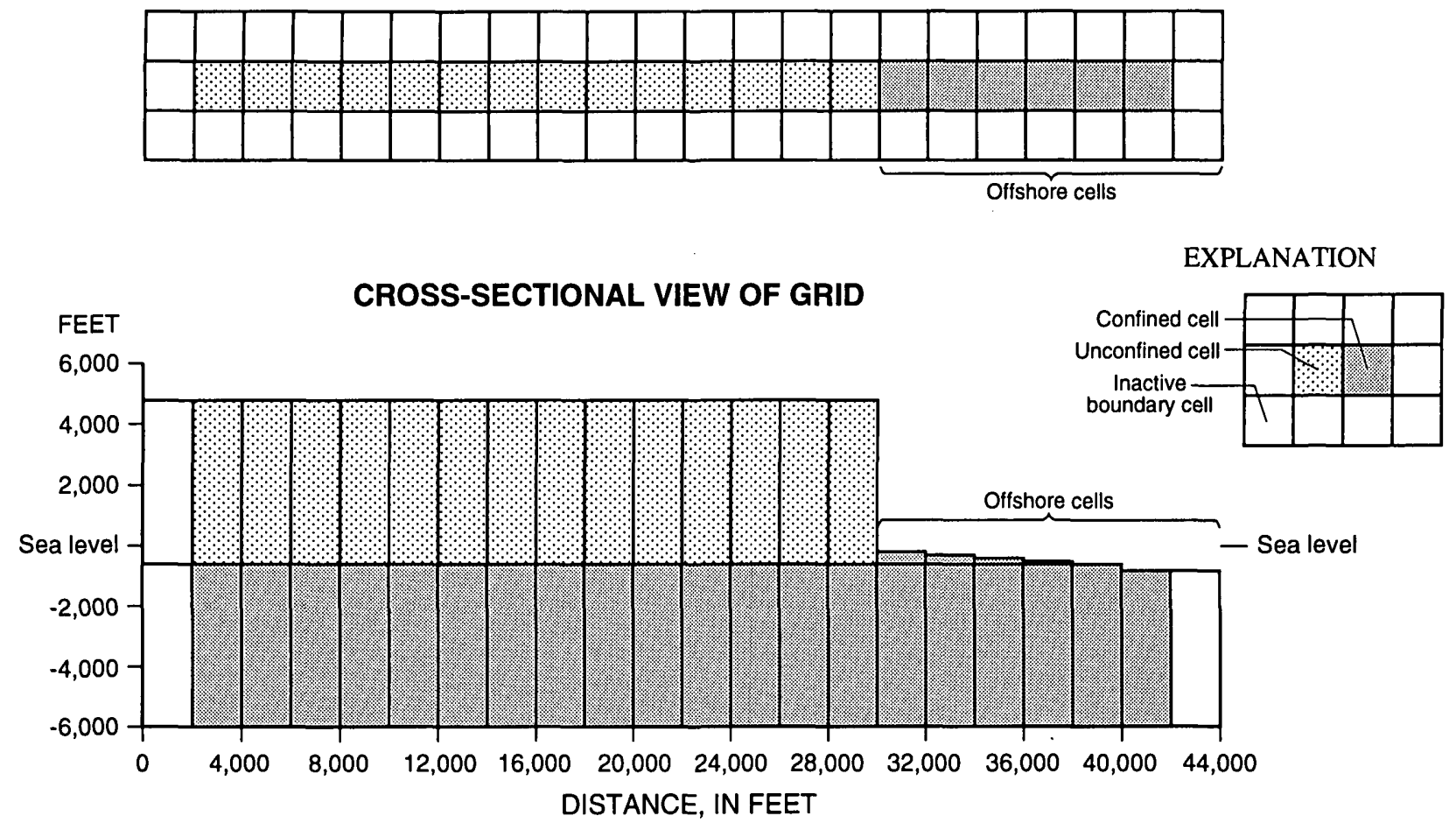

Figure A8. Structure of the model used to test the modified SHARP program.

\section{CHANGES TO PROGRAM DATA-INPUT FILE}

The modified SHARP program requires modification of the data-input file. For the original version of SHARP, $l$ for each cell was contained in the AQL array of the data-input file (Essaid, 1990, p. 123). For the modified SHARP program, the AQL array contains initial values of $l$ that will be recalculated as the program iterates to a solution. Because recalculation of $l$ may not be appropriate for all cells, the user specifies, by entering a negative value for $l$ in the AQL array, which cells will have $l$ recomputed during the simulation. At each iteration, the program checks the sign of the initial value of $l$ at each cell. If the sign is positive, the value of $l$ is left unchanged. If the sign is negative, the program recomputes a new $l$ at each iteration on the basis of changing freshwater and saltwater thicknesses. Except for the positive/negative signs, the format of the AQL array in the data-input file of the modified SHARP program is the same as for the original program (Essaid, 1990, p. 123). The program preserves the positive/ negative sign of the initial $l$ in an array called AQLI while the AQL array is used to store the updated values of $l$.

For the original version of SHARP, $K$ was lumped into $l$ (Essaid, 1990, p. 15). For the modified SHARP program, $K$ is defined in a new array FKV. The FKV array is inserted after the AQL array and has the same dimensions and formatting as the FKX and FKY arrays of the original SHARP program.

\section{TESTS OF THE MODIFIED PROGRAM}

The program modification was tested with a two-layer strip model simulating flow in a coastal aquifer (fig. A8). The model was created using the modified SHARP program and the input data in table A2 and was allowed to run to steady state. The resulting steady-state aquifer leakances were compared with leakances computed by hand directly from equations $\mathrm{A} 1, \mathrm{~A} 2, \mathrm{~A} 7$, and $\mathrm{A} 8$ (for convenience, the results are separated into tables $\mathrm{A} 3-\mathrm{A} 9$ according 
to the form of the leakance equation used for the hand calculation). The model calculated a total of 24 leakance values: 4 between the upper layer and the ocean, 2 between the lower layer and the ocean, and 18 between upper and lower layers. All of the leakances computed by the modified SHARP program agreed precisely with the leakances computed by hand from the formulas.

To ensure that the program modifications worked correctly within the context of the original SHARP program, both the original and modified SHARP programs were run using the same data-input file (except for differences required by the modified SHARP program, such as the vertical FKV array and negative signs in the AQL array to indicate which leakances are to be recalculated; aquifer leakances used for the original SHARP program came from the modified SHARP program). Both programs were run until steady state was achieved. A comparison of the results (table A10) shows that the heads and interface elevations from the modified SHARP program agreed within 0.004 percent of the heads and interface elevations from the original SHARP program. These tests indicate that the modified SHARP program correctly recomputes leakances according to the governing equations as freshwater and saltwater thicknesses change during the iterative solution process.

Table A2. Summary of selected characteristics and input data of the numerical model used to test the modified SHARP program.

[ $K_{h}$, horizontal hydraulic conductivity; $K_{v}$ vertical hydraulic conductivity; datum is mean sea level]

\begin{tabular}{ll}
\hline Cell horizontal dimensions & 2,000 feet by 2,000 feet \\
Number of rows & 3 \\
Number of columns & 20 \\
Elevation of top of model & varies \\
Elevation of bottom of upper layer, top of lower layer & -500 feet \\
Elevation of bottom of model & $-6,000$ feet \\
$K_{h}$ of lower-layer active cells & 10 feet per day \\
$K_{v}$ of lower-layer active cells & 10 feet per day \\
$K_{h}$ of upper-layer active cells & 20 feet per day \\
$K_{v}$ of upper-layer active cells & 20 feet per day \\
Recharge at all onshore upper-layer active cells & 20 inches per year \\
Length of time step & 10 days \\
Steady-state criterion & 0.001 feet \\
\hline
\end{tabular}

\footnotetext{
${ }^{a}$ Steady state considered to be achieved in the simulation when maximum head change between time steps is less than the steady-state criterion.
} 
Table A3. Freshwater vertical leakance between unconfined upper-layer cells and confined lower-layer cells [Datum is mean sea level]

\begin{tabular}{ccccc}
\hline \multirow{2}{*}{ Column } & $\begin{array}{c}\text { Interface elevation, } \\
\text { lower layer } \\
\text { (feet) }\end{array}$ & $\begin{array}{c}\text { Water-table elevation } \\
\text { (feet) }\end{array}$ & & \multicolumn{2}{c}{ Vertical leakance (second ${ }^{-1}$ ) } \\
\cline { 3 - 4 } & $-3,499.9$ & 87.400 & From equation & $\begin{array}{c}\text { From modified SHARP }^{1} \\
\text { program }\end{array}$ \\
\hline 2 & $-3,481.5$ & 86.942 & $7.03 \times 10^{-8}$ & $7.03 \times 10^{-8}$ \\
3 & $-3,444.4$ & 86.019 & $7.07 \times 10^{-8}$ & $7.07 \times 10^{-8}$ \\
4 & $-3,388.2$ & 84.618 & $7.15 \times 10^{-8}$ & $7.15 \times 10^{-8}$ \\
5 & $-3,312.0$ & 82.719 & $7.28 \times 10^{-8}$ & $7.28 \times 10^{-8}$ \\
6 & $-3,214.6$ & 80.290 & $7.46 \times 10^{-8}$ & $7.46 \times 10^{-8}$ \\
7 & $-3,094.5$ & 77.289 & $7.70 \times 10^{-8}$ & $7.70 \times 10^{-8}$ \\
8 & $-2,949.3$ & 73.657 & $8.03 \times 10^{-8}$ & $8.03 \times 10^{-8}$ \\
9 & $-2,775.9$ & 69.310 & $8.46 \times 10^{-8}$ & $8.46 \times 10^{-8}$ \\
0 & $-2,569.6$ & 64.127 & $9.04 \times 10^{-8}$ & $9.04 \times 10^{-8}$ \\
11 & $-2,323.3$ & 57.924 & $9.84 \times 10^{-8}$ & $9.84 \times 10^{-8}$ \\
12 & $-2,025.7$ & 50.406 & $1.10 \times 10^{-7}$ & $1.10 \times 10^{-7}$ \\
13 & $-1,655.3$ & 41.048 & $1.28 \times 10^{-7}$ & $1.28 \times 10^{-7}$ \\
14 & & & $1.62 \times 10^{-7}$ & $1.62 \times 10^{-7}$ \\
\hline
\end{tabular}

${ }^{1}$ Equation:

where:

$$
l=\frac{1}{\frac{b_{1}}{K_{1}}+\frac{b_{2}}{K_{2}}},
$$

elevation of top of lower layer = elevation of bottom of upper layer $=-500$ feet,

$l \quad=$ vertical leakance,

$b_{1}=$ half the thickness of freshwater in lower layer $=0.5[(-500 \mathrm{feet})-($ interface elevation in lower layer $)]$,

$b_{2}=$ half the thickness of freshwater in the upper layer $=0.5[$ (water-table elevation $)-(-500$ feet $)$,

$K_{1}=$ vertical hydraulic conductivity of lower layer $=10$ feet per day $=1.157 \times 10^{-4}$ feet per second, and

$K_{2}=$ vertical hydraulic conductivity of lower layer $=20$ feet per day $=2.315 \times 10^{-4}$ feet per second. 
Table A4. Saltwater vertical leakance between upper-layer confined offshore cells and lower-layer confined cells

\begin{tabular}{cccc}
\hline Column & $\begin{array}{c}\text { Bathymetry } \\
\text { (feet) }\end{array}$ & \multicolumn{2}{c}{ Vertical leakance (second ${ }^{-1}$ ) } \\
\cline { 2 - 4 } & -200 & $4.10 \times 10^{-8}$ & From modified SHARP program $^{-8}$ \\
\hline 17 & -300 & $4.13 \times 10^{-8}$ & $4.10 \times 10^{-8}$ \\
18 & -400 & $4.17 \times 10^{-8}$ & $4.13 \times 10^{-8}$ \\
19 & & & $4.17 \times 10^{-8}$ \\
\hline
\end{tabular}

${ }^{1}$ Equation:

where:

$$
l=\frac{1}{\frac{b_{1}}{K_{1}}+\frac{b_{2}}{K_{2}}},
$$

elevation of top of lower layer $=$ elevation of bottom of upper layer $=-500$ feet,

elevation of bottom of lower layer $=-6,000$ feet,

$l \quad=$ vertical leakance,

$b_{1}=$ half the thickness of saltwater in lower layer $=0.5[(-500$ feet $)-(-6,000$ feet $)]$,

$b_{2}=$ half the thickness of saltwater in upper layer $=0.5$ [(bathymetry $)-(-500$ feet $)$ ],

$K_{1}=$ vertical hydraulic conductivity of lower layer $=10$ feet per day $=1.157 \times 10^{-4}$ feet per second, and

$K_{2}=$ vertical hydraulic conductivity of lower layer $=20$ feet per day $=2.315 \times 10^{-4}$ feet per second.

Table A5. Saltwater vertical leakance between lower-layer cells and the ocean

\begin{tabular}{cccc}
\hline \multirow{2}{*}{ Column } & $\begin{array}{c}\text { Bathymetry } \\
\text { (feet) }\end{array}$ & \multicolumn{2}{c}{ Vertical leakance (second ${ }^{-1}$ ) } \\
\cline { 3 - 4 } & -500 & $4.21 \times 10^{-8}$ & From modified SHARP program $^{-8}$ \\
\hline 20 & -600 & $4.29 \times 10^{-8}$ & $4.21 \times 10^{-8}$ \\
21 & & $K_{1}$ & $4.29 \times 10^{-8}$ \\
\hline${ }^{1}$ Equation: & $l=\frac{1}{b_{1}}$,
\end{tabular}

where:

elevation of bottom of lower layer $=-6,000$ feet,

$l=$ vertical leakance,

$b_{1}=$ half the thickness of saltwater in lower layer $=0.5$ [(bathymetry $)-(-6,000$ feet $)$, and

$K_{1}=$ vertical hydraulic conductivity of lower layer $=10$ feet per day $=1.157 \times 10^{-4}$ feet per second. 
Table A6. Saltwater vertical leakance for upper-layer cells exchanging water with the ocean

\begin{tabular}{|c|c|c|c|}
\hline \multirow{2}{*}{ Column } & \multirow{2}{*}{$\begin{array}{c}\text { Bathymetry } \\
\text { (feet) }\end{array}$} & \multicolumn{2}{|c|}{ Vertical leakance $\left(\right.$ second $^{-1}$ ) } \\
\hline & & From equation ${ }^{1}$ & From modified SHARP program \\
\hline 17 & -200 & $1.54 \times 10^{-6}$ & $1.54 \times 10^{-6}$ \\
\hline 18 & -300 & $2.31 \times 10^{-6}$ & $2.31 \times 10^{-6}$ \\
\hline 19 & -400 & $4.63 \times 10^{-6}$ & $4.63 \times 10^{-6}$ \\
\hline IEquation: & & $l=\frac{K_{2}}{b_{2}}$ & . \\
\hline
\end{tabular}

where:

elevation of bottom of upper layer $=-500$ feet,

$l \quad=$ vertical leakance,

$b_{2}=$ half the thickness of saltwater in upper layer $=0.5$ [(bathymetry $)-(-500$ feet $\left.)\right]$, and

$K_{2}=$ vertical hydraulic conductivity of upper layer $=20$ feet per day $=2.315 \times 10^{-4}$ feet per second. 
Table A7. Vertical leakance between an unconfined upper-layer cell and a confined lower-layer cell, where the freshwater/ saltwater interface intersects the bounding face between the cells

[Datum is mean sea level]

\begin{tabular}{|c|c|c|c|c|c|c|}
\hline \multirow[b]{2}{*}{ Column } & \multirow[b]{2}{*}{$\begin{array}{l}\text { Interface elevation, } \\
\text { lower layer (feet) }\end{array}$} & \multirow[b]{2}{*}{$\begin{array}{c}\text { Water-table } \\
\text { elevation } \\
\text { (feet) }\end{array}$} & \multirow[b]{2}{*}{${ }^{A} f_{1}$} & \multirow[b]{2}{*}{$A_{s_{2}}$} & \multicolumn{2}{|c|}{ Vertical leakance $\left(\right.$ second $^{-1}$ ) } \\
\hline & & & & & From equation' & $\begin{array}{l}\text { From modified } \\
\text { SHARP program }\end{array}$ \\
\hline 15 & $-1,143.8$ & 28.947 & 1.000 & 0.082 & $2.16 \times 10^{-7}$ & $2.16 \times 10^{-7}$ \\
\hline \multicolumn{7}{|l|}{${ }^{1}$ Equation: } \\
\hline & & & $l=$ & & & \\
\hline
\end{tabular}

where:

elevation of top of lower layer = elevation of bottom of upper layer $=-500$ feet,

elevation of bottom of lower layer $=-6,000$ feet,

$l \quad=$ vertical leakance,

$b_{1} \quad=$ freshwater/saltwater thickness in lower layer scaled by freshwater area and saltwater areas

$$
=0.25\left(T_{f_{1}}\left(A_{f_{1}}\right)+T_{s_{1}}\left(1-A_{f_{1}}\right)+T_{s_{1}}\left(A_{s_{2}}\right)+T_{f_{1}}\left(1-A_{s_{2}}\right)\right)
$$

$b_{2}=$ freshwater/saltwater thickness in upper layer scaled by freshwater area and saltwater areas

$$
=0.25\left(T_{f_{2}}\left(A_{f_{1}}\right)+T_{s_{2}}\left(1-A_{f_{1}}\right)+T_{s_{2}}\left(A_{s_{2}}\right)+T_{f_{2}}\left(1-A_{s_{2}}\right)\right)
$$

$T_{f_{1}}=$ freshwater thickness in lower layer $=(-500$ feet $)-($ interface elevation in lower layer $)$,

$A_{f_{1}}=$ proportion of the area on the top face of the lower cell occupied by freshwater,

$T_{s_{1}}=$ saltwater thickness in lower layer = - (interface elevation in lower layer $)-(-6000$ feet $)$,

$A_{s_{2}}=$ proportion of the area on the bottom face of the upper cell occupied by saltwater,

$T_{f_{2}}=$ freshwater thickness in upper layer $=($ water table elevation $)-(-500$ feet $)$,

$T_{s_{2}}=$ saltwater thickness in upper layer $=0$ in this case,

$K_{1}=$ vertical hydraulic conductivity of lower layer $=10$ feet per second $=1.157 \times 10^{-4}$ feet per second, and

$K_{2}=$ vertical hydraulic conductivity of upper layer $=20$ feet per second $=2.315 \times 10^{-4}$ feet per second. 
Table A8. Vertical leakance between a confined upper-layer cell and a confined lower-layer cell, where the freshwater/saltwater interface intersects the bounding face between the cells

[Datum is mean sea level]

\begin{tabular}{|c|c|c|c|c|c|c|c|}
\hline \multirow[b]{2}{*}{ Column } & \multirow{2}{*}{$\begin{array}{c}\text { Interface } \\
\text { elevation in } \\
\text { lower layer } \\
\text { (feet) }\end{array}$} & \multirow{2}{*}{$\begin{array}{c}\text { Interface } \\
\text { elevation in } \\
\text { upper layer } \\
\text { (feet) }\end{array}$} & \multirow[b]{2}{*}{${ }^{A} f_{1}$} & \multirow[b]{2}{*}{$A_{s_{2}}$} & \multirow[b]{2}{*}{$\begin{array}{c}\text { Bathymetry } \\
\text { (feet) }\end{array}$} & \multicolumn{2}{|c|}{ Vertical leakance $\left(\right.$ second $^{-1}$ ) } \\
\hline & & & & & & From equation 1 & $\begin{array}{l}\text { From modified } \\
\text { SHARP program }\end{array}$ \\
\hline 16 & -624.71 & -119.97 & 0.740 & 1.000 & -100 & $6.51 \times 10^{-8}$ & $6.51 \times 10^{-8}$ \\
\hline Equation: & & & & 1 & & & \\
\hline
\end{tabular}

where:

elevation of top of lower layer $=$ elevation of bottom of upper layer $=-500$ feet,

elevation of bottom of lower layer $=-6,000$ feet,

$l \quad=$ vertical leakance,

$b_{1}=$ freshwater/saltwater thickness in lower layer scaled by freshwater area and saltwater areas

$$
=0.25\left(T_{f_{1}}\left(A_{f_{-1}}\right)+T_{s_{1}}\left(1-A_{f_{1}}\right)+T_{s_{1}}\left(A_{s_{2}}\right)+T_{f_{1}}\left(1-A_{s_{2}}\right)\right),
$$

$b_{2} \quad=$ freshwater/saltwater thickness in upper layer scaled by freshwater area and saltwater areas

$$
=0.25\left(T_{f_{2}}\left(A_{f_{1}}\right)+T_{s_{2}}\left(1-A_{f_{1}}\right)+T_{s_{2}}\left(A_{s_{2}}\right)+T_{f_{2}}\left(1-A_{s_{2}}\right)\right),
$$

$T_{f_{1}}=$ freshwater thickness in lower layer $=(-500$ feet $)-($ interface elevation in lower layer $)$,

$A_{f_{1}}=$ proportion of the area on the top face of the lower cell occupied by freshwater,

$T_{s_{1}}=$ saltwater thickness in lower layer = (interface elevation in lower layer $)-(-6,000$ feet $)$,

$A_{s_{2}}=$ proportion of the area on the bottom face of the upper cell occupied by saltwater,

$T_{f_{2}}=$ freshwater thickness in upper layer = (bathymetry) - (interface elevation in upper layer),

$T_{s_{2}}=$ saltwater thickness in upper layer = (interface elevation in upper layer $)-(-500$ feet $)$,

$K_{1}=$ vertical hydraulic conductivity of lower layer $=10$ feet per second $=1.157 \times 10^{-4}$ feet per second, and

$K_{2}=$ vertical hydraulic conductivity of lower layer $=20$ feet per second $=2.315 \times 10^{-4}$ feet per second. 
Table A9. Vertical leakance between the ocean and a confined upper-layer cell in which the freshwater/saltwater interface intersects the top face of the cell

[FAREA, proportion of the area on the top face of the lower-layer cell occupied by saltwater; datum is mean sea level]

\begin{tabular}{cccccc}
\hline Column & $\begin{array}{c}\text { Interface elevation, } \\
\text { upper layer } \\
\text { (feet) }\end{array}$ & $\begin{array}{c}\text { FAREA } \\
\text { upper layer }\end{array}$ & $\begin{array}{c}\text { Bathymetry } \\
\text { (feet) }\end{array}$ & Vertical leakance (second ${ }^{-1}$ ) \\
\hline 16 & -119.97 & 0.518 & -100 & $2.39 \times 10^{-6}$ & From equation $^{1}$ \\
SHARP program \\
\hline${ }^{1}$ Equation:
\end{tabular}

where:

elevation of bottom of upper layer $=-500$ feet,

$l \quad=$ vertical leakance,

$b_{2} \quad=$ freshwater/saltwater thickness in cell scaled by freshwater and saltwater areas on top face of cell

$$
=0.5\left(T_{f_{2}}\left(A_{f_{2}}\right)+T_{s_{2}}\left(1-A_{f_{2}}\right)\right),
$$

$T_{f_{2}}$ = freshwater thickness in upper layer= (bathymetry) - (interface elevation in upper layer),

$A_{f_{2}}=$ FAREA of upper layer,

$T_{s_{2}}=$ saltwater thickness in upper layer = (interface elevation in upper layer $)-(-500$ feet $)$, and

$K_{2}=$ vertical hydraulic conductivity of upper layer $=20$ feet per second $=2.315 \times 10^{-4}$ feet per second. 
Table A10. Comparison of results from modified and original versions of the SHARP program [Datum is mean sea level]

\begin{tabular}{|c|c|c|c|c|c|c|c|c|}
\hline \multirow{2}{*}{ Column } & \multicolumn{2}{|c|}{$\begin{array}{l}\text { Freshwater head in } \\
\text { lower layer (feet) }\end{array}$} & \multicolumn{2}{|c|}{$\begin{array}{l}\text { Freshwater/saltwater interface } \\
\text { elevation in lower layer (feet) }\end{array}$} & \multicolumn{2}{|c|}{$\begin{array}{l}\text { Freshwater head in } \\
\text { upper layer (feet) }\end{array}$} & \multicolumn{2}{|c|}{$\begin{array}{l}\text { Freshwater/saltwater interface } \\
\text { elevation in upper layer (feet) }\end{array}$} \\
\hline & $\begin{array}{l}\text { Modified } \\
\text { SHARP }\end{array}$ & $\begin{array}{l}\text { Original } \\
\text { SHARP }\end{array}$ & $\begin{array}{l}\text { Modified } \\
\text { SHARP }\end{array}$ & $\begin{array}{l}\text { Original } \\
\text { SHARP }\end{array}$ & $\begin{array}{l}\text { Modified } \\
\text { SHARP }\end{array}$ & $\begin{array}{l}\text { Original } \\
\text { SHARP }\end{array}$ & $\begin{array}{l}\text { Modified } \\
\text { SHARP }\end{array}$ & $\begin{array}{l}\text { Original } \\
\text { SHARP }\end{array}$ \\
\hline 1 & 0.000 & 0.000 & 0.000 & 0.000 & 0.000 & 0.000 & 0.000 & 0.000 \\
\hline 2 & 86.867 & 86.870 & $-3,499.946$ & $-3,500.038$ & 87.400 & 87.403 & $-3,560.000$ & $-3,560.000$ \\
\hline 3 & 86.414 & 86.417 & $-3,481.528$ & $-3,481.619$ & 86.942 & 86.945 & $-3,520.000$ & $-3,520.000$ \\
\hline 4 & 85.502 & 85.505 & -3444.446 & $-3,444.536$ & 86.019 & 86.022 & $-3,480.000$ & $-3,480.000$ \\
\hline 5 & 84.119 & 84.122 & $-3,388.198$ & $-3,388.289$ & 84.618 & 84.621 & $-3,440.000$ & $-3,440.000$ \\
\hline 6 & 82.243 & 82.246 & $-3,311.984$ & $-3,312.072$ & 82.719 & 82.722 & $-3,320.000$ & $-3,320.000$ \\
\hline 7 & 79.845 & 79.848 & $-3,214.635$ & $-3,214.720$ & 80.290 & 80.293 & $-3,240.000$ & $-3,240.000$ \\
\hline 8 & 76.883 & 76.886 & $-3,094.515$ & $-3,094.600$ & 77.289 & 77.292 & $-3,120.000$ & $-3,120.000$ \\
\hline 9 & 73.300 & 73.302 & $-2,949.343$ & $-2,949.424$ & 73.657 & 73.659 & $-3,000.000$ & $-3,000.000$ \\
\hline 10 & 69.013 & 69.016 & $-2,775.907$ & $-2,775.983$ & 69.310 & 69.312 & $-2,800.000$ & $-2,800.000$ \\
\hline 11 & 63.907 & 63.909 & $-2,569.568$ & $-2,569.637$ & 64.127 & 64.129 & $-2,600.000$ & $-2,600.000$ \\
\hline 12 & 57.804 & 57.806 & $-2,323.307$ & $-2,323.367$ & 57.924 & 57.926 & $-2,360.000$ & $-2,360.000$ \\
\hline 13 & 50.418 & 50.419 & $-2,025.698$ & $-2,025.750$ & 50.406 & 50.408 & $-2,040.000$ & $-2,040.000$ \\
\hline 14 & 41.210 & 41.211 & $-1,655.260$ & $-1,655.305$ & 41.048 & 41.050 & $-1,680.000$ & $-1,680.000$ \\
\hline 15 & 28.473 & 28.474 & $-1,143.775$ & $-1,143.823$ & 28.947 & 28.948 & $-1,155.849$ & $-1,155.867$ \\
\hline 16 & 15.543 & 15.543 & -624.709 & -624.704 & 3.058 & 3.058 & -119.967 & -119.964 \\
\hline 17 & -0.046 & -0.046 & 0.000 & 0.000 & 0.000 & 0.000 & 0.000 & 0.000 \\
\hline 18 & -0.028 & -0.028 & 0.000 & 0.000 & 0.000 & 0.000 & 0.000 & 0.000 \\
\hline 19 & -0.018 & -0.018 & 0.000 & 0.000 & 0.000 & 0.000 & 0.000 & 0.000 \\
\hline 20 & -0.012 & -0.012 & 0.000 & 0.000 & 0.000 & 0.000 & 0.000 & 0.000 \\
\hline 21 & -0.010 & -0.010 & 0.000 & 0.000 & 0.000 & 0.000 & 0.000 & 0.000 \\
\hline 22 & 0.000 & 0.000 & 0.000 & 0.000 & 0.000 & 0.000 & 0.000 & 0.000 \\
\hline
\end{tabular}




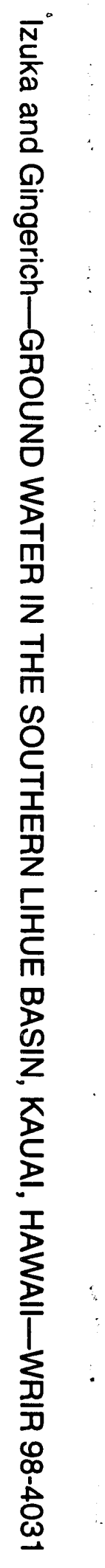

